University of Pennsylvania Carey Law School

Penn Law: Legal Scholarship Repository

Faculty Scholarship at Penn Law

1984

\title{
Allocational Sanctions: The Problem of Negative Rights in a Positive State
}

Seth F. Kreimer

University of Pennsylvania Carey Law School

Follow this and additional works at: https://scholarship.law.upenn.edu/faculty_scholarship

Part of the Common Law Commons, Constitutional Law Commons, Criminal Law Commons, Jurisprudence Commons, Natural Law Commons, and the Public Policy Commons

\section{Repository Citation}

Kreimer, Seth F., "Allocational Sanctions: The Problem of Negative Rights in a Positive State" (1984). Faculty Scholarship at Penn Law. 1413.

https://scholarship.law.upenn.edu/faculty_scholarship/1413

This Article is brought to you for free and open access by Penn Law: Legal Scholarship Repository. It has been accepted for inclusion in Faculty Scholarship at Penn Law by an authorized administrator of Penn Law: Legal Scholarship Repository. For more information, please contact PennlawIR@law.upenn.edu. 


\title{
ALLOCATIONAL SANGTIONS: THE PROBLEM OF NEGATIVE RIGHTS IN A POSITIVE STATE
}

\author{
SETH F. KREIMER $\dagger$ \\ TABLE OF GONTENTS
}

INTRODUCTION . . . . . . . . . . . . . . . . . . . 1294

I. Prior Analyses of Allocational Sanctions ..... 1301

A. Introduction . . . . . . . . . . . . . . . . 1301

B. Doctrines of Judicial Deference ............. 1304

1. The Classical Doctrine of the Greater and the

Lesser ........................... 1304

2. Two Emerging Errors: Negative Rights in a Positive State ................... 1314

a. The Sovereign/Proprietary Distinction .. 1315

b. Positive and Negative Rights: The Problematic Distinction Between Action and Inaction ....................... 1324

G. Doctrines of Active Review . . . . . . . . . . . 1326

1. Unconstitutional Purpose.............. 1327

a. Purpose Analysis and Constitutional Rights: The History ............ 1327

b. The Attraction of Purpose .......... 1333

c. The Problems of Purpose .......... 1333

2. Unconstitutional Impact ............ 1340

3. Balancing and Reasonableness .......... 1347

II. Towards a Revised ANalysis of Allocational

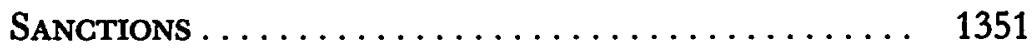

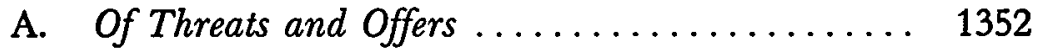

1. History as a Baseline ............... 1359

2. Equality as a Baseline............. 1363

3. Prediction as a Baseline ............ 1371

$\dagger$ Assistant Professor of Law, University of Pennsylvania. B.A. 1974, Yale University; J.D. 1977, Yale University.

My thinking about this article has benefited considerably from the time and effort of my colleagues Albert Alschuler, C. Edwin Baker, Paul Bender, Frank Goodman, Virginia Kerr, and Steven Schulhofer, as well as Owen Fiss, in providing me with comments and criticism. Similarly, my excellent research assistants Teresa Gillen and Adam Thurschwell have each provided a contribution that should not go unacknowledged. My thanks is theirs, all blame for remaining errors is mine. 
4. Constitutional Triangulation ............. 1374

B. Inalienable Rights? ................... 1378

1. The Appeal of Analogy................. 1380

2. The Problem of Waiver ............. 1382

a. Waivable and Non-waivable Rights..... 1387

b. Alienable and Inalienable Rights...... 1389

c. The Propriety of Government Requests for

Waiver ........................ 1391

C. The Problem of Remedy: The Right to be a Policeman Revisited ........................... 1393

Conclusion $\ldots \ldots \ldots \ldots \ldots \ldots \ldots \ldots \ldots \ldots \ldots, 1395$

\section{INTRODUCTION}

Half a century ago, the New Deal officially inaugurated government's active participation in the regulation and provision of economic benefits. The emergence of this positive state has led roughly a generation of constitutional scholars to wrestle in earnest with its implications for the Bill of Rights. ${ }^{1}$

1 The previous generation of constitutional scholars took as its central challenge the justification of governmental intervention in free market transactions despite Supreme Court opposition in such cases as Lochner v. New York, 198 U.S. 45 (1905), and Hammer v. Dagenhart (Child Labor Case), 247 U.S. 251 (1918). See, e.g., Merrill, Unconstitutional Conditions, 77 U. PA. L. REv. 879 (1929). See generally L. Tribe, American Constrtutional Law §§ 8-2 to 8-7 (1978).

When the Supreme Court abandoned its opposition, with West Coast Hotel Co. v. Parrish, 300 U.S. 379 (1937), attention shifted to the impact governmental intervention might have on personal constitutional rights to political liberty or equality. The earliest, and in many ways most insightful, discussion of the constitutional impact of government largesse is to be found in Professor Chafee's examination of government facilities, funding, and licensing in the communications field: Z. ChafeE, Government and Mass Communications (1947).

Several articles have dealt specifically with the impact of attaching unconstitutional conditions to the allocation of governmental benefits. See, e.g., French, Unconstitutional Conditions: An Analysis, 50 GEO. L.J. 234 (1961); Hale, Unconstitutional Conditions and Constitutional Rights, 35 Colum. L. REv. 321 (1935); Note, Unconstitutional Conditions, 73 Harv. L. REv. 1595 (1960); Comment, Another Look at Unconstitutional Conditions, 117 U. PA. L. Rev. 144 (1968).

During the McCarthy era considerable writing was prompted by the conditioning of government licenses and employment on loyalty oaths or political orthodoxy. See, e.g., W. Gellhorn, Individual Freedom and Governmental Restraints (1956); Davis, The Requirement of a Trial-Type Hearing, 70 HaRv. L. REv. 193 (1956); Miller, Government Contracts and Social Control: A Preliminary Inquiry, 41 VA. L. Rev. 27 (1955); Willcox, Invasions of the First Amendment Through Conditioned Public Spending, 41 CoRNELL L.Q. 12 (1955); Note, Judicial Acquiescence in Forfeiture of Constitutional Rights Through the Expansion of the Conditioned Privilege Doctrine, 28 IND. L.J. 520 (1953); Note, Civil Disabilities and the First Amendment, 78 YALE L.J. 842 (1969); cf. Note, Denying the Privilege Against Self-Incrimination to Public Officers, 64 HARV. L. REV. 987 (1951). 
In the past, much constitutional thinking centered on limiting the use of coercive force or criminal sanctions through which government has traditionally exerted its authority to deter undesirable conduct. However, this conception of negative rights as freedom from coercive violence has questionable value in shaping constitutional restraints on a government that more often exerts its power by withholding benefits than by threatening bodily harm. Whether conditioning federal funds for hospitals on the provision of approved treatment for genetically defective newborn children, ${ }^{2}$ requiring colleges to eschew discrimination as a condition of access to student loans or tax exemptions, ${ }^{3}$ or extracting promises of silence as a condition of government employment, ${ }^{4}$ increasingly visible governmental actions substantially impinge on individual lives without invoking the threat of mayhem or incarceration.

More recent scholarship has been prompted by modern legislation that has administered public employment or welfare benefits on conditions at war with constitutional rights. See K. Davis, Discretionary Justice 162-87 (1969); T. Emerson, The SYSTEM OF FREEDOM OF EXPREsSion 161-246 (1970); Davis, Veterans' Benefits, Judicial Review, and the Constitutional Problems of "Positive" Government, 39 IND. L.J. 183 (1964); Linde, Constitutional Rights in the Public Sector: Justice Douglas on Liberty in the Welfare State, 40 WASH. L. REv. 10 (1965); O'Neil, Unconstitutional Conditions: Welfare Benefits with Strings Attached, 54 CALIF. L. REv. 443 (1966); Reich, Individual Rights and Social Welfare: The Emerging Legal Issues, 74 YALE L.J. 1245 (1965); Reich, The New Property, 73 Yale L.J. 733 (1964); Van Alstyne, The Constitutional Rights of Public Employees: A Comment on the Inappropriate Uses of an Old Analogy, 16 UCLA L. REv. 751 (1969); Van Alstyne, The Demise of the Right-Privilege Distinction in Constitutional Law, 81 HARv. L. REv. 1439 (1968).

2 See American Academy of Pediatrics v. Heckler, 561 F. Supp. 395 (D.D.C. 1983) (striking down regulation that conditioned federal funds for hospitals on provision of life support systems for genetically defective newborn children without regard to parental consent).

3 See Grove Gity Gollege v. Bell, 104 S. Ct. 1211, 1223 (1984) (requiring compliance with Title IX as condition of federal support); Bob Jones Univ. v. United States, 103 S. Ct. 2017 (1983) (tax exemption denied to university with explicit policy forbidding interracial dating or marriage); Wright v. Regan, 656 F.2d 820 (D.C. Cir. 1981) (challenge to tax exemption for racially discriminatory private school), cert. granted 103 S. Ct. 3109 (1983); cf. Doe v. Selective Serv. Sys., 557 F. Supp. 937 (D. Minn. 1983), cert. granted sub nom. Selective Serv. Sys. v. Boe, 104 S. Ct. 522 (1984) (challenge to Solomon Amendment, 50 U.S.C.A. $\S 462 f$ (West Supp. 1982), which requires draft registration as condition of eligibility for student loans).

- President Reagan recently ordered a lifelong requirement that all government employees with access to confidential information obtain prior government approval for any speech or publication, including fiction, that touches on knowledge gained through such access. His directive also authorizes random polygraph examinations of government employees, both at hiring and throughout employment. See National Security Decision Directive - 84 on Safeguarding National Security Information (Mar. 11, 1983), cited in H.R. ReP. No. 578, 98th Cong., 1st Sess. 3 n.2 (1983). The General Accounting Office estimates that this directive will affect roughly 2.5 million government employees and an additional 1.3 million employees of Defense Department contractors. The overinclusiveness of such regulation is extraordinary. In 1982 the government discovered only 21 unauthorized disclosures of information; to combat this, it administered 23,000 polygraph exams. Id. at 8,14 . 
The greatest force of a modern government lies in its power to regulate access to scarce resources. ${ }^{5}$

Government agencies, for example, employ from fourteen to twenty percent of the workforce, ${ }^{\beta}$ and the combined expenditures of both local and federal governments range from thirty to thirty-five per cent of the Gross National Product. ${ }^{7}$ With government's increased regulation of and participation in the economy and its inheritance of educational and welfare functions from the church and family, opportunities abound for governmental intrusion through allocation of benefits. While allocational sanctions may not always be as drastic as criminal ones, they are more pervasive. Potential victims need not be sought out; they come to the state seeking benefits. ${ }^{8}$

Courts encounter difficulties when imposing constitutional restraints on governmental allocations. A primary justification for restraint-government's monopoly on the legitimate use of force ${ }^{9}$-is not

- The manipulation by government of material inducements to control behavior is not unique to the United States. See, e.g., E. Etzioni-Halevy, Political Manipulation and Administrative Power: A Comparative Study (1979) (examining Australia, Britain, Israel, and the United States); Isaacs, Reproductive Rights 1983: An International Survey, 14 Colum. Hum. RTS. L. REv. 311, 317-18 \& nn. $42-45$ (1982-83) (discussing government manipulation of financial incentives, housing priorities, and maternity and childcare benefits to reduce birth rates in China, India, Korea, Singapore, Thailand, and elsewhere).

- See Bureau of the Census, U.S. Dep't of Commerce, Statistical ABSTRACT OF THE UnIted States 303, 376 (103d ed. 1982) [hereinafter Statistical ABSTRACT] (federal, state, and local governments employ 16 million of a total employed workforce of 100 million). This phenomenon is not new. The percentage of the workforce employed by the public sector has exceeded $15 \%$ for nearly 45 years. See $\mathrm{T}$. Stanbeck, JR., P. Bearse, T. Noyelle \& R. Karasek, Services: The New EconOMY 12-13 table 1.2 (1981).

7 See Statistical ABSTRACT, supra note 6, at 273, 416 (total government expenditure of $\$ 959$ billion comprised $32 \%$ of the Gross National Product in 1981). Professor Gellhorn has noted that particular sectors of the economy may be especially vulnerable to government restraints. Over half of all hardback books in the United States were bought by government agencies or adapted pursuant to their instructions. See W. Gellhorn, Individual FreEdom and Governmental Restraints 78 (1956).

8 As the Court has recognized, the necessity of going to the state to obtain a benefit or fulfill a requirement may itself be a burden. Cf. Zablocki v. Redhail, 434 U.S. $374,387 \&$ n.12 (1978) (parents of children from prior marriage must obtain court order certifying their ability to support those children not in their custody before remarrying; burden of obtaining the order itself infringes constitutionally protected rights). Imposing conditions on desirable benefits eases enforcement of the conditions. See, e.g., Law Tying Draft Registration to College Aid Gains Results, N.Y. Times, Apr. 22, 1984, $\S 1$, at 1 , col. 2 (registration for draft, previously enforced by criminal penalty, rose from $90 \%$ to $99 \%$ after enactment of the Solomon Amendment (see supra note 3)); $c f$. Lavin, Registration Drive, WASH. MonThLy, Apr. 1983, at 47 (suggesting that 18-year olds be required to register for the draft when they obtain driver's licenses).

- Government's monopoly on legitimate violence enables it to accomplish the greatest possible harm; no individual or private entity could have laid waste to Viet- 
as clearly applicable when the government buys, sells, and bribes through the use of concededly legitimate powers. Conferring benefits, even selectively, seems to increase individual liberty by expanding the choices available. Any surrender of individual rights in exchange appears to be voluntary and without need for judicial supervision.

Nor do courts have as logical a role in reviewing allocational decisions as they do in reviewing criminal sanctions. Most governmental applications of force already occur through the judicial system. Although police are authorized to apply force directly in emergencies, coercive sanctions are usually preceded by criminal prosecutions. Courts are thoroughly familiar, in this area, both with doctrine and with practical ramifications. By contrast, benefits are allocated directly by executive or legislative acts; any constitutional restraint requires positive judicial intervention. Courts must reach out and affirmatively intrude into unfamiliar territory. ${ }^{10}$ Such affirmative intervention forces courts to forego the pretense of neutrality. Any remedial decree specifically orders a specific allocation, rather than merely forbidding one alternative and leaving democratic processes to choose from the remainder. And courts are notoriously poor at allocating resources. ${ }^{11}$

In recent years, the difficulties raised by the indirect constitutional infringements of the positive state have appeared on the Supreme Court docket with increasing frequency. ${ }^{12}$ Legislators and administrators of

nam. Government's ability to use force also insulates it from opposition, effectively checking even the most powerful private parties. Blasi, The Checking Value in First Amendment Theory, 1977 AM. B. FOuND. RESEARCH J. 521, 538-39.

10 As Professor Chafee put the matter,

The Court will, I think, be somewhat more reluctant to upset postal restrictions on discussion than criminal convictions for speaking and writing. Here, the fact that the postal service is a great and complicated business does have significance. . . . In judicial matters the Justices know their way around - "born and bred in a brier patch." They are well aware of the consequences of reversing a decision below. They can go far because they are well acquainted with the precise point where they ought to stop before going too far. . . . It is quite otherwise if the Court upsets a ruling by the Postmaster General, especially if the ruling represents an habitual practice, and not just an isolated case.

Z. Chafee, Government and Mass Communications 281 (1947).

${ }^{11}$ See, e.g, Winter, Poverty, Economic Equality, and the Equal Protection Clause, 1972 Sup. CT. REv. 41, 93-97.

12 For an example of a conflict between constitutional rights and provision of government funds and services, see, e.g., Harris v. McRae, 448 U.S. 297 (1980) (conflict between right to abortion and restricted medicaid funding); supra note 3.

For examples of conflicts between ordinances regulating access to government property and first amendment rights, see, e.g., Heffron v. International Soc'y for Krishna Consciousness, Inc., 452 U.S. 640 (1981) (restricting distribution of religious materials at public fair); Carey v. Brown, 447 U.S. 455 (1980) (voiding statute prohibiting residential picketing). 
all political stripes are acutely aware of the usefulness of allocational sanctions as tools for influencing behavior. ${ }^{13}$ The Court, however, has yet to adopt a coherent framework for analyzing the constitutionality of these sanctions.

The problem, of course, is not new, as the pedigree of the unconstitutional conditions doctrine attests. Examination of the doctrine's development, however, suffers from a disorienting quality. While the same arguments are made today as at the doctrine's inception, over the last century, the arguments have migrated across the spectrum of politi-

For examples of conflicts between unemployment compensation provisions and freedom of religion guarantees, see, e.g., California v. Grace Brethren Church, 457 U.S. 393 (1982) (reversing invalidation of requirement that teachers in church affiliated schools contribute to state unemployment compensation program); United States v. Lee, 455 U.S. 252 (1982) (upholding requirement that Amish employer pay social security tax despite religious objections); Thomas v. Review Bd., 450 U.S. 707 (1981) (holding unemployment compensation may not be denied to plaintiff who refused to work on military equipment when such work violated his religious beliefs).

For examples of conflicts between control of school facilities and equal protection and first amendment rights, see, e.g., Board of Educ. v. Pico, 457 U.S. 853 (1982) (refusal of school library to purchase certain books); Plyler v. Doe, 457 U.S. 202 (1982) (public education may not be denied children of illegal aliens); Widmar v. Vincent, 454 U.S. 263 (1981) (state university may not deny use of facilities to religious group).

The right to travel has been infringed by government largesse. See Zobel v. Williams, 457 U.S. 55 (1982) (striking down Alaskan scheme to distribute oil royalties on basis of length of residence); $c f$. White v. Massachusetts Council of Constr. Employers, Inc., 103 S. Ct. 1042 (1983) (upholding requirement that government contractors hire local workers against commerce clause challenge). And postal restrictions have conflicted with first amendment rights. See United States Postal Serv. v. Council of Greenburgh Civic Ass'ns, 453 U.S. 114 (1981) (upholding regulation that prohibits deposit of unstamped mail in private mailboxes).

${ }^{13}$ Certainly the desire to influence behavior with allocational sanctions lies behind the legislation restricting abortion funding. See, e.g., Harris v. McRae, 448 U.S. 297 (1980); Maher v. Roe, 432 U.S 464 (1977); Poelker v. Doe, 432 U.S. 519 (1977) (upholding restrictions). A number of state courts have voided such restrictions as impermissible infringements of state constitutional guarantees. See, e.g., Committee to Defend Reproductive Rights v. Meyers, 29 Cal. 3d 252, 625 P.2d 779, 172 Gal. Rptr. 866 (1981); Moe v. Secretary of Admin. \& Fin., 382 Mass. 629, 417 N.E.2d 387 (1981); Right to Choose v. Byrne, 91 N.J. 287, 450 A.2d 925 (1982); Fischer v. Department of Pub. Welfare, 497 Pa. 267, 439 A.2d 1172 (1982). The United States Supreme Court cases in this area seem to me particularly heartless and misguided in their result. But in this I am biased, having been one of a team of counsel in Fischer.

Examples of allocations intended to influence behavior are numerous in other areas as well. See, e.g., United Bldg. \& Constr. Trades Council v. Camden, 52 U.S.L.W. 4187, 4191 (U.S. Feb. 21, 1984) (No. 81-2110) (requirement that $40 \%$ of employees of municipal contractors be local residents); Planned Parenthood Fed'n of Am. v. Heckler, 712 F.2d 650 (D.C. Cir. 1983) (federal regulation conditioning funds for family planning clinics on requirement that they notify parents when prescribing contraceptive devices for minors); National Alliance v. United States, 710 F.2d 868 (D.C. Cir. 1983) (denying tax exempt status to racist publication); see also Philadelphia Inquirer, Mar. 4, 1984, at 3-A, col. 3 (Salvation Army loses over four million dollars in city contrasts for refusing to pledge non-discrimination against homosexuals). 
cal views in counterpoint to the Court's political center of gravity. ${ }^{\mathbf{1 4}}$ Justice Rehnquist is the legatee of the doctrine used by Justices Holmes and Brandeis in their efforts to immunize social legislation from judicial review, ${ }^{16}$ while Justice Brennan wields an analysis forged by Justices Sutherland and Day in their attempts to contain the growth of government regulation of corporate interests. ${ }^{16}$

To be sure, not everything is so neat. The first Justice Harlan, though hardly sympathetic to entrenched interests, aligned himself strongly with efforts to limit government's power to allocate favors, ${ }^{17}$ and Justice Holmes's long career saw occasional retreats from his generally deferential approach to governmental powers. ${ }^{18}$ But even in these

14 During the era of Lochner v. New York, 198 U.S. 45 (1905), constitutional rights primarily protected property. Government regulation of corporate interests fell victim to constitutional scrutiny, and doctrines that limited the scope of Supreme Court review permitted greater regulation. See, e.g., Beck, Nullification by Indirection, 23 HaRv. L. REv. 441 (1910) (need for doctrine to confine regulation); Oppenheim, Unconstitutional Conditions and State Powers, 26 MICH. L. REv. 176, 179 (1927) (doctrine of unconstitutional conditions "bloomed in fields where federal protection of widespread corporate property rights was essential").

At least one early commentator argued against the expansion of the unconstitutional conditions doctrine, believing that allowing government to exert allocative, but not criminal, authority over otherwise unregulable enterprise was an appropriate compromise with constitutional limitations on the government power left over from an earlier era. See Merrill, Unconstitutional Conditions, 77 U. PA. L. REv. 879, 889-91 (1929).

However, in the years following World War II, as the Court's enforcement of constitutional rights leaned toward personal liberties, conservatives took up the fight for government's ability to allocate favors free of the constraints of the unconstitutional conditions doctrine. These partisans defended the government's ability to impose constraints on its citizenry by means of conditional benefits, even though the constraints would be impermissible if adopted by criminal regulation. See, e.g., Adler v. Board of Educ., 342 U.S. 485 (1952) (upholding civil service regulation prohibiting any member of subversive group from teaching in public school); infra text accompanying notes 4148, 69-74.

${ }^{16}$ See infra text accompanying notes $32-48,69-74$.

16 See, e.g., Frost \& Frost Trucking Co. v. Railroad Comm'n, 271 U.S. 583 (1926) (striking statute requiring that private carriers become public carriers in return for privilege of using road); supra text accompanying notes 164-78.

17 See, e.g., Pullman Co. v. Kansas, 216 U.S. 56 (1910). Justice Harlan joined Justice Day in opinions sharing this sentiment. See, e.g., Hammer v. Dagenhart (Child Labor Case), 247 U.S. 251 (1918) (holding unconstitutional prohibition of interstate trade in products of child labor); Security Mut. Life Ins. Co. v. Prewitt, 202 U.S. 246, 266-67 (1906) (Day \& Harlan, JJ., dissenting) (arguing that state cannot condition business license on surrender of right to remove lawsuits to federal court). But even Justice Harlan occasionally changed sides. See, e.g., Atkin v. Kansas, 191 U.S. 207 (1903) (upholding federal wage and hour restrictions on laborers employed by government contractors); Cumming v. Richmond County Bd. of Educ., 175 U.S. 528, 542 (1899) (government may allocate tax revenues to schools as it sees fit).

18 See, e.g., Fidelity \& Deposit Co. v. Tafoya, 270 U.S. 426, 435 (1926) (striking statute suspending license of in-state insurance companies that remitted premiums out of state); United States ex rel. Milwaukee Social Democratic Publishing Co. v. Burleson, 255 U.S. 407, 437-38 (1921) (Holmes, J., dissenting) (arguing that Postmas- 
anomalous cases, the Justices did not so much repudiate their prior positions as simply exchange them for the analyses of their opposite numbers. ${ }^{19}$

Given the continued prevalence of these traditional doctrines, analysis logically begins by recounting their origins and examining their use by the Court. This is the enterprise of part I.

I seek to draw two conclusions from historical analysis. First, the use of allocational sanctions is subject to constitutional constraint. Although an old lesson, it is one that deserves periodic reiteration. On a regular basis, Supreme Court opinions begin and end with invocation of the traditional doctrines that preclude active judicial review of allocational sanctions. Such claims of immunity are both pernicious and unfounded.

Second, when the Court does undertake active review, there are no easy answers to be found. Despite its undoubted attractions, an inquiry into governmental purpose is both analytically and practically flawed. Nor can the problem be circumvented by the belief that there is no difference between what the government may achieve with carrots or with sticks. Offers and threats differ, in at least some circumstances, and such differences need not be left to ad hoc balancing.

Rather, I suggest in part II that the problem of allocational sanctions must be analyzed in two stages. First, courts must distinguish between threats and offers. Threats are allocations that make a citizen

ter ought not be given unreviewable authority to deny access to mails); Western Union Tel. Co. v. Foster, 247 U.S. 105, 114 (1918) (state may not intervene in interstate commerce by requiring broker's admittance to tickertape service).

19 For a particularly illustrative example of this minuet, see Missouri ex rel. Burnes Nat'l Bank v. Duncan, 265 U.S. 17 (1924) (requiring that states allow nationally chartered banks to become executors in state courts). Justice Holmes, writing for the majority, vindicated federal power at the expense of the state. He discounted the state's general power over its courts, noting that "[t]he States cannot use their most characteristic powers to reach unconstitutional results" and citing two unconstitutional conditions cases from which he had dissented. Id. at 24. Justice Sutherland, as the author of Frost \& Frost Trucking Co. v. Railroad Comm'n, 271 U.S. 583 (1926), echoed Justice Holmes in Burnes in writing that a state might not bring about results outside its power "by imposing the unconstitutional requirement as a condition precedent to the enjoyment of a privilege." 271 U.S. at 592. But, in Burnes, Sutherland dissented, arguing that, because the state could have excluded both federally chartered banks and trust companies, it had the discretion to admit either. See 265 U.S. at 28-29.

For a more recent instance of this exchange, see FERC v. Mississippi, 456 U.S. 742 (1982). Justice Blackmun, normally a critic of allocational sanctions, writing for the majority and joined by Justices Brennan, Marshall, Stevens, and White, repeated Justice Sutherland's Burnes reasoning: because Congress could have preempted state regulation of utilities entirely, its imposition of conditions on the state regulation was constitutional. See 456 U.S. at 765. Justices Burger, O'Connor, and Rehnquist, usually receptive to government's claim to unrestrained prerogatives, adopted the earlier arguments of Justice Holmes in Burnes in rejecting this rationale. See 456 U.S. at 777-81. 
worse off than she otherwise would be because of her exercise of a constitutional right. Offers merely expand her range of options, leaving the citizen better off. For example, an offer by the National Endowment for the Arts to provide grants to citizens who choose to write symphonies rather than jazz differs fundamentally from a threat to withdraw welfare payments if the citizen chooses jazz over symphonies. Both allocations influence a constitutionally protected choice, but a threat abridges first amendment rights in ways an offer does not. The crucial task is to specify an appropriate baseline against which to determine whether the proposed allocation improves or worsens the citizen's situation. The first section of part II proposes three baselines and offers an analytic framework for assessing the constitutionality of allocational sanctions that use the proposed baselines.

Threats are subject to constitutional constraints, although courts may find compelling governmental interests that justify prima facie infringements. Offers will not be subject to restraint unless, proceeding to the second step of the analysis, courts find that the rights discouraged are inalienable. If so, then the government should be prohibited from offering to buy the rights no less than from threatening to punish their exercise. The second section of this part of the Article considers the constitutionality of allocational sanctions that impinge upon inalienable rights.

The difficulties of neatly categorizing allocational sanctions are rooted both in our conception of constitutional rights and in the way we view the nature of government's responsibility for the welfare of its citizens. The analysis developed in part II seeks to provide a framework within which to order discourse and to test judicial intuition. My hope is not to build a system that automatically resolves all of the cases, for hard cases abound. Rather, the analysis set forth succeeds if it at least gets the easy cases right, explains why the hard cases are hard, and allows argument to center on the appropriate factual and legal issues.

\section{Prior Analyses of Allocational Sanctions}

\section{A. Introduction}

Even a government that does no more than impose criminal sanctions retains the opportunity to trade its protection for the relinquishment of other rights. Most elements of the modern unconstitutional conditions conundrum surfaced long before the emergence of a positive 
state. In $1821,{ }^{20}$ the Tennessee legislature attempted to circumvent the prohibition that states not issue paper money as legal tender ${ }^{21}$ by passing a statute that delayed execution on any plaintiff's judgment in a civil case for two years unless the creditor agreed to accept notes issued by Tennessee as payment. The Tennessee Supreme Court's consideration of that statute in Townsend $v$. Townsend $d^{22}$ prefigured a century and a half of subsequent argument.

The state argued that it had not made its notes legal tender but had merely offered speedier execution to creditors who would accept it as such. According to the state, the availability of execution in less than two years, was purely a gratuitous benefit. "The assembly . . . have a right to suspend execution, because they may place the terms of the Court at such a distance form each other as to make it impossible for a creditor to entitle himself to execution in less than two, three, or more years ...."2s

The Tennessee court was unpersuaded. As to the voluntary nature of the acceptance, Judge Haywood noted, "Whatever he is not bound to receive, [the creditor] cannot be punished for refusing. . . . Suspension of execution is a penalty if, but for the Act, the creditor would be entitled to it . . . ."24 Since timely execution had previously been available, denial of that execution constituted an impermissible penalty for declining to accept the scrip.

Even granting the state's claim that the right to execution might be suspended or conditioned by the legislature, the court held that the condition would be void: "By such inventions every constitutional right may in succession be bartered away. Constitutional rights are vested, unexchangeable, and unalienable. They belong to posterity as well as to the present generation. We may use and enjoy, but not transfer them; and every such condition is utterly void."25

${ }^{20}$ The general problem of misuse of conceded power is substantially older. Compare 2 Samuel 11:1-27 (David orders Uriah sent to a dangerous combat position where Uriah is killed. David marries his widow.) with Oestereich v. Selective Serv. Sys. Local Bd. No. 11, 393 U.S. 233 (1968) (draft exemption revoked in retaliation for antiwar protest).

${ }^{21}$ U.S. ConsT. art. I, $\S 10$, cl. 1.

227 Tenn. (Peck) 1 (1821).

23 Id. at 15 , Peck at 18 .

24 Id. at 9, Peck at 11-12.

2s Id. at 10 , Peck at 12 . The other positive activity undertaken by the "minimal" antebellum federal government-postal service-was subject to similar manipulations. In 1835 President Andrew Jackson urged Congress to withdraw the privilege of using the mails from antislavery propagandists. The bill that would have implemented the suggestion was rejected by Congress on free speech grounds, as was a similarly motivated measure to bar from the mails any item that the state of the recipient had banned. Immediately before the Civil War, the Postmaster General unilaterally ordered 
Similar clashes occurred two generations later with the attempts to establish loyalty oaths as conditions for obtaining state or federal licenses and positions. ${ }^{28}$ Proponents emphasized that barring non-oath takers was not a criminal penalty and that the government had plenary authority to deny the licenses and positions entirely. ${ }^{27}$ Opponents successfully argued that any decrease in the opportunities available to a citizen was a penalty within the contemplation of the ex post facto and bill of attainder clauses and that all governmental functions must be undertaken within constitutional constraints. ${ }^{28}$

At the turn of the century, the flowering of the substantive rights of business under the contract clause and the fourteenth amendment clashed with attempts by state populists to contain emerging corporate

the nondelivery of certain abolitionist newspapers. During the War, the taint of southern sedition was used to bar delivery of critical newspapers, still without congressional authorization. See D. Fowler, Unmailable 26-34 (1977); Deutsch, Freedom of the Press and of the Mails, 36 Mich. L. REv. 703, 717-27 (1938); Rogers, The Postal Power of Congress: $A$ Study in Constitutional Expansion, 34 JoHNs HopkINs UNIv. Stud. IN HIST. \& PoL. ScI., No. 2, 1, 103-15 (1916); Sigler, Freedom of the Mails: A Developing Right, 54 GEo. L.J. 30 (1965).

Similarly, from 1851 to 1875 , within a generally subsidized system of newspaper delivery by mail, subscribers who lived within 100 miles of where the paper was printed were provided with lower mailing rates than were available to those who were beyond that radius. The explicit intention of the discount was to protect rural readers from the "poisoned sentiments of the city, . . . concentrated in their papers . . . "W. Fuller, The American MaIl: Enlarger of the Common Life 114 (1972); I. de Sola Pool, Technologies of Freedom 79 (1983).

Early cases tended to accept the proposition that "[t]he legislative body in thus establishing a postal service may annex such conditions to it as it chooses." Public Clearing House v. Coyne, 194 U.S. 497, 506 (1904). See United States ex rel. Milwaukee Soc. Democratic Publishing Co. v. Burleson, 255 U.S. 407 (1921) (upholding revocation of second class mail permit for criticism of the government); Ex parte Jackson, 96 U.S. 727 (1877) (government may exclude unfit material from the mails).

Cases during the last 40 years, however, have largely voided governmental restrictions on the use of the mails. See, e.g., Blount v. Rizzi, 400 U.S. 410 (1971) (striking down Postmaster's censorship scheme as lacking sufficient first amendment safeguards); Lamont v. Postmaster General, 381 U.S. 301 (1965) (striking down statute prohibiting delivery of communist propaganda except on written request of recipient); Hannegan v. Esquire, Inc., 327 U.S. 146 (1946) (striking down revocation of second class mail permit for material deemed vulgar by Postmaster). As ever, the best analysis of this progression is also one of the earliest: Z. CHAFEe, supra note 10, at 276-366. See also I. DE Sola Pool, supra, at 79-91; Deutsch, supra; Sigler, supra.

${ }^{26}$ See, e.g., Ex parte Garland, 71 U.S. (4 Wall.) 333 (1867); Cummings v. Missouri, 71 U.S. (4 Wall.) 277 (1867). But see Ex parte Hunter, 2 W. Va. 122 (1867) (upholding oath). See generally H. Hyman \& W. Wiecek, Equal Justice UNDER Law 373-85, 551 (1982); H. Hyman, Era of the OATH: Northern Loyalty Tests DURING THE Givil WaR and Reconstruction (1954).

${ }^{27}$ See Ex parte Garland, 71 U.S. (4 Wall.) 333, 353, 356-57 (1867); Cummings v. Missouri, 71 U.S. (4 Wall.) 277, 2932-94 (1867).

${ }^{28}$ See Ex parte Garland, 71 U.S. (4 Wall.) 333, 340-48 (1867); Cummings v. Missouri, 71 U.S. (4 Wall.) 277, 286-89 (1867). 
power. ${ }^{29}$ Constitutionally prohibited from direct criminal regulation of business, states adopted allocational sanctions. Across the West, state legislatures attempted to parlay their conceded authority over the right of foreign corporations to do business within their jurisdictions into limitations on corporate activities-limitations they could not have imposed directly.

As earlier studies have noted, these cases manifested an inconsistency so marked as to make a legal realist of almost any reader.$^{30}$ Yet it was these decisions that gave birth to the unconstitutional conditions doctrines embraced by modern jurists. Therefore, an attempt to come to terms with the problem of allocative sanctions appropriately begins by accounting for the durability of these earlier doctrines, and recounting their weaknesses.

\section{B. Doctrines of Judicial Deference}

\section{The Glassical Doctrine of the Greater and the Lesser}

Although courts have occasionally defended allocational sanctions on the ground that the victim retains the choice of noncompliance, ${ }^{31}$ the

29 See L. Tribe, American Constitutional Law $\S 8-1$, at 433 (1978).

30 For the classic analysis, see Hale, Unconstitutional Conditions and Constitutional Rights, 35 Colum. L. REv. 321 (1935). For other analyses, see G. Henderson, The Position of Foreign Corporations in american Constitutional Law - [ch.5] (1918); French, Unconstitutional Conditions: An Analysis, 50 GEo. L.J. 234 (1961); Merrill, supra note 14; see also Western \& S. Life Ins. Co. v. State Bd., 451 U.S. 648, 656-667 (1982) (reviewing history of unconstitutional conditions attached to state licensing of corporations and attempting to modulate sine-wave swings into a smooth progression); Hale, Force and the State: A Comparison of "Political" and "Economic" Compulsion, 35 Colum. L. Rev. 150 (1935).

A particularly vivid example of this inconsistency is provided by the line of cases that alternately permitted and prohibited the conditioning of insurance company licenses on the applicant insurer's repudiation of its right to remove cases to federal court. See Insurance Co. v. Morse, 87 U.S. (20 Wall.) 445 (1874) (invalidating condition); Doyle v. Continental Ins. Co., 94 U.S. 535 (1876) (permitting revocation of license in retaliation for removal of suit); Barron v. Burnside, 121 U.S. 186 (1887) (following Morse; license may not be revoked for removal); Security Mut. Life Ins. Co. v. Prewitt, 202 U.S. 246 (1906) (following Doyle and upholding revocation); Terral v. Burke Constr. Co., 257 U.S. 529 (1922) (overruling Prewitt and Doyle).

s1 Defenders of governmental prerogatives have long grasped the rhetorical advantages of characterizing governmental intervention as an offer of benefits rather than as a threat of sanctions. The government, it was said, did not violate constitutional rights simply by offering a benefit for favored conduct. The citizen retained the choice of complying or not. Thus, dissenters in the Civil War loyalty oath cases defended the oath's constitutionality on the ground that "[n]o person is pointed out in the act of Congress . . . . The oath is only required of those who propose to accept an office or to practise law . . . . It is not, then, the act of Congress, but the party interested, that tries and condemns." Ex parte Garland, 71 U.S. (4 Wall.) 333, 389-90 (1867) (Miller, J., dissenting).

In cases concerning corporate regulation, proponents-both successful and unsuc- 
most resilient defense is that "[e]ven in the law the whole generally

cessful - of state authority distinguished situations in which the state compelled conduct in violation of constitutional rights from those situations in which the state made such conduct a condition of corporate access to a benefit. The majority, in Doyle v. Continental Ins. Co., 94 U.S. 535 (1876), denied the dissenters' accusation that it had permitted the states to force corporations to forego their federally guaranteed right of access to federal courts, arguing: "This is an 'inexact statement.' The effect of our decision in this respect is that the State may compel the foreign company to abstain from the Federal courts, or to cease to do business in the State. It gives the company the option." 94 U.S. at 542. See also Security Mut. Life Ins. Co. v. Prewitt, 202 U.S. 246, 252 (1906); Pullman Co. v. Adams, 189 U.S. 420, 422 (1903) ("The company cannot complain of being taxed for the privilege of doing a local business which it is free to renounce."); cf. Coppage v. Kansas, 236 U.S. 1, 21 (1915) ("To ask a man to agree, in advance, to refrain from affiliation with the union while retaining a certain position of employment is not to ask him to give up any part of his constitutional freedom. He is free to decline the employment on those terms.").

Justice Holmes also took up this theme: "The whole matter is left in the Western Union's hands . . . . If the Telegraph Company chooses to pay the fee [on intrastate business] out of its other earnings that is its affair. It is master of the situation and can stop if it sees fit." Western Union Tel. Co. v. Kansas, 216 U.S. 1, 53-54 (1910) (Holmes, J., dissenting).

Although the argument has long been discredited in the area of corporate regulation, see Terral v. Burke Constr. Co., 257 U.S. 529, 532-33 (1922), it continued to be a viable rationale for the infringement of personal liberties. See, e.g., Hamilton v. Regents of the Univ. of Cal., 293 U.S. 245, 262 (1934) (Military training may be required as a condition of attendance at state university: "Galifornia has not drafted or called them to attend the university. They are seeking education offered by the State ....."); see also id. at 266 (Cardozo, J., concurring) ("If they elect to resort to an institution for higher education maintained with the state's money, then and only then are they commanded . . . ."); $c f$. West Va. Bd. of Educ. v. Barnette, 319 U.S. 624, 631-32 (1943) (holding unconstitutional requirement that public school students salute American flag; the Court distinguished Hamilton, noting that attendance at public school was required, while university attendance was elective).

A similar analysis underlay decisions sustaining "loyalty" programs of the McCarthy era. See, e.g., Adler v. Board of Educ., 342 U.S. 485, 492 (1952) (public school teachers barred from subversive activities retain the choice of working subject to restrictions or of maintaining "their beliefs and associations and go[ing] elsewhere"); American Communications Ass'n v. Douds, 339 U.S. 382, 403-04 (1950) (requirement that union officials sign affidavit denying communist allegiance does not violate first amendment: the officers may maintain their beliefs "subject only to possible loss of positions"); cf. Beilan v. Board of Pub. Educ., 357 U.S. 399, 405 (1958) (inquiry into teachers' political beliefs justified by nature of their position).

Such reasoning, that those on whom a condition is imposed retain the choice to avoid the condition, has been largely unavailing in modern personal rights cases. See, e.g., McDaniel v. Paty, 435 U.S. 618 (1978) (invalidating statute that barred ministers from public office); Keyishian v. Board of Regents, 385 U.S. 589 (1967) (invalidating loyalty oath requirement for teachers); Torcaso v. Watkins, 367 U.S. 488 (1961) (holding unconstitutional a requirement that state employees declare belief in God). But see Oklahoma v. United States Civil Serv. Comm'n, 330 U.S. 127, 142 (1947) (upholding Hatch Act prohibition of public employees from political activity against tenth amendment challenge); Stewart, Pyramids of Sacrifice? Problems of Federalism in Mandating State Implementation of National Environmental Policy, 86 YALE L.J. 1196, 1250-62, $1252 n_{1} 205$ (1977) (choice of noncompliance sufficient for tenth amendment purposes).

Nonetheless, the argument is not dormant. The Court continues to argue, on occasion, that no right has been violated because the state has not forbidden its exercise. See, e.g., Wyman v. James, 400 U.S. 309, 317-18 (1971) (conditioning welfare benefits 
includes its parts. If the State may prohibit, it may prohibit with the privilege of avoiding the prohibition in a certain way." ment may deny the claimant at will, the claimant appears no worse off when the government exercises that denial because of the claimant's failure to comply with a condition attached to the entitlement.

Justice Holmes made this point repeatedly. In rejecting a claim that the refusal to allow a rally on the Boston Commons infringed freedom of speech, he asserted,

For the Legislature absolutely or conditionally to forbid public speaking in a highway or public park is no more an infringement of the rights of a member of the public than for the owner of a private house to forbid it in his house. . . . [T] he Legislature may end the right of the public to enter upon the public place by putting an end to the dedication to public uses. So it may take the lesser step of limiting the public use to certain purposes. ${ }^{33}$

Speaking in dissent fifteen years later, Holmes reiterated his inability

to understand how a condition can be unconstitutional when attached to a matter over which a State has absolute arbitrary power. . . .

The consequence is the measure of the condition. When

on consent to home inspection by social worker; "[T] or compelled and ... the beneficiary's denial of permission is not a criminal act. If consent . . . is withheld, .. . [t]he aid then never begins or merely ceases."); Shapiro v. Thompson, 394 U.S. 618, 650 (1969) (Warren, C.J., dissenting) (arguing that to condition welfare benefits on residency does not bar right to travel).

This argument has surfaced in recent Terms. See, e.g., Grove City College v. Bell, 104 S. Ct. 1211, 1223 (1984) (conditioning federal funds on nondiscrimination does not infringe first amendment rights; "Grove City may terminate its participation in the .. program and thus avoid the requirements ... . Requiring Grove City to comply ... infringes no First Amendment rights."); Finnegan v. Leu, 456 U.S. 431, 440 (1982) (union officials dismissed for supporting insurgent union candidate; "[P]etitioners allege only an indirect interference [with their first amendment rights] ... maintaining that they were forced to 'choos[e] between their rights of free expression . . . and their jobs." ") (quoting Retail Clerks Union Local 648 v. Retail Clerks Int'l Ass'n, 299 F. Supp. 1012, 1021 (D.D.C. 1969)); Haig v. Agee, 453 U.S. 280, 309 (1981) (upholding revocation of passport for unpatriotic activity; denial was only "an inhibition of action, rather than of speech. . . . Agee is as free to criticize the United States Government as he was when he held a passport.") (quoting Zemel v. Rusk, 381 U.S. 1, 16 (1965)) (emphasis supplied by Court).

Such blithe dismissal of constitutional protections is far too simplistic. See infra text accompanying notes $220-96$ for my attempt to construct an appropriate framework of analysis.

${ }^{32}$ Western Union Tel. Co. v. Kansas, 216 U.S. 1, 53 (1910) (Holmes, J., dissenting).

s3 Commonwealth v. Davis, 162 Mass. 510, 511 (1895), affd, 167 U.S. 43 (1897). 
the only consequence of a breach in a result that the State may bring about directly in the first place, the condition cannot be unconstitutional. ${ }^{34}$

Justice Holmes has not been alone in his analysis. The state of Tennessee, in Townsend $v$. Townsend, ${ }^{\text {s5 }}$ unsuccessfully argued that, because the legislature could deprive plaintiffs of execution of their judgments by closing the courts entirely, execution could be denied to those who insisted on being paid in hard currency. Years later, Civil War loyalty oaths were defended, with mixed success, on the similar theory that the oaths were preconditions to privileges the government might deny entirely. ${ }^{36}$

In 1876, this doctrine of the "greater and lesser" provided the basis for the holding that a state could withdraw the business license of a foreign corporation in retaliation for the corporation's invocation of federal diversity jurisdiction. ${ }^{37}$ To a dissenting claim that the state had imposed an "unconstitutional condition" on the right to do business, ${ }^{38}$ the majority replied, "If the State has the power to cancel the license ... [i]t has the power to determine for what causes and in what manner the revocation shall be made."s9 This doctrine prevailed intermittently in the field of foreign corporations for the next sixty-five years. ${ }^{40}$

34 Western Union Tel. Co. v. Kansas, 216 U.S. 1, 53 (1910) (Holmes, J., dissenting). The argument that an absolute power necessarily includes the power to impose conditions recurs elsewhere in Justice Holmes's reasoning. See, e.g., Frost \& Frost Trucking Co. v. Railroad Comm'n, 271 U.S. 583, 602 (1926) (Holmes, J., dissenting) (" "IT]he power to exclude altogether generally includes the lesser power to condition ....' ") (quoting Packard v. Banton, 264 U.S. 140, 145 (1924)); City and County of Denver v. Denver Union Water Co., 246 U.S. 178, 196-97 (1918) (Holmes, J., dissenting) (Gity may require water company to close altogether; therefore, it may set water rates at any price.); $c f$. Hammer v. Dagenhart (Child Labor Case), 247 U.S. 251, 277-81 (1918) (prohibition of interstate trade in products of child labor held unconstitutional) (Holmes, J., dissenting) (if government has a power, it cannot be curtailed because of its indirect effects).

Similar reasoning led Justice Holmes to reject an antitrust challenge to the tying of patented and non-patented products. He argued that absolute control over the patented product justified conditions on its availability. See Motion Picture Patents Co. v. Universal Film Mfg. Co., 243 U.S. 502, 519-20 (1917) (Holmes, J., dissenting).

85 7 Tenn. (Peck) 1 (1821).

so See supra notes $26-28$ and accompanying text.

37 See Doyle v. Continental Ins. Co., 94 U.S. 535 (1876).

${ }^{38}$ Id. at 543 (Bradley, J., dissenting).

39 Id. at 542; see also cases cited supra note 34.

${ }^{40}$ Doyle v. Continental Ins. Co., 94 U.S. 535 (1876), was effectively reversed by Barron v. Burnside, 121 U.S. 186 (1887) (state may not prohibit foreign corporation from removing suit to federal court as condition of doing business). This, in turn, was overruled by Security Mut. Life Ins. Co. v. Prewitt, 202 U.S. 246, 257 (1906) (license to do business may be revoked for removal; "As a state has power to refuse permission to ... do business at all, ... it has the power to withdraw that permission when once given without stating any reason for its action . . . ."). 
Similar reasoning sustained arbitrary governmental actions in other constitutionally sensitive areas until the last years of the Warren Court. ${ }^{11}$ Later Justices usually appended a disclaimer that the exercise of a governmental prerogative could not, "of course," discriminate on the basis of race, religion, or political affiliation. ${ }^{42}$

Nonetheless, the ghost of Justice Holmes's greater and lesser argument continues to brood over much constitutional analysis. ${ }^{43}$ In the criminal area echoes of the doctrine have rung down forcefully even during the last Term. ${ }^{44}$ Elsewhere, Justice Rehnquist has consistently

Identical reasoning is found in cases upholding a state's right to tax foreign corporations doing in-state business. See Lincoln Nat'l Life Ins. Co. v. Read, 325 U.S. 673, 678 (1945) ("The State, having the power to exclude entirely, has the power to change the conditions of admission at any time ...." ") (quoting Philadelphia Fire Ass'n v. New York, 119 U.S. 110, 119 (1886)); Atlantic Refining Co. v. Virginia, 302 U.S. 22 (1937); Packard v. Banton, 264 U.S. 140 (1924); Horn Silver Mining Co. v. New York, 143 U.S. 305 (1892); Philadelphia Fire Ass'n v. New York, 119 U.S. 110, 119 (1886); $c f$. Western \& S. Life Ins. Co. v. State Bd., 451 U.S. 648 (1981) (foreign corporations doing business in California must pay "retaliatory tax" equal to that charged California corporations doing business in the foreign corporation's home state).

\$1 See, e.g., Barsky v. Board of Regents, 347 U.S. 442, 451 (1954) (medical licenses); Hamilton v. Regents of the Univ. of Cal., 293 U.S. 245 (1934) (state university attendance); United States v. MacIntosh, 283 U.S. 605, 615 (1931) (naturalization); Heim v. McCall, 239 U.S. 175 (1915) (public works employment); Bailey v. Richardson, 182 F.2d 46 (1950) (same), affd mem. by equally divided court, 341 U.S. 819 (1951).

${ }^{2}$ See, e.g., Barsky v. Board of Regents, 347 U.S. 442, 451 (1954) (practice of medicine is within sphere of state's regulation, but regulation must be reasonable); United Pub. Workers v. Mitchell, 330 U.S. 75, 100 (1947) (public employees may be restrained from political activity but could not be subjected to racial or religious restrictions); $c f$. Adler v. Board of Educ., 342 U.S. 485, $492-93$ (1952) (government may bar Communists from teaching positions, but it may not abridge their freedom of speech in general); American Communications Ass'n v. Douds, 339 U.S. 382, 402-05 (1950) (requirement that union officials sign affidavit denying communist allegiance does not violate first amendment).

4 See, e.g., Minneapolis Star \& Tribune Co. v. Minnesota Comm'r of Revenue, 103 S. Ct. 1365, 1378-79 (1983) (Rehnquist, J., dissenting) (arguing that because newspapers could constitutionally be required to pay a more costly sales tax, imposition of a "lesser" special tax on newsprint should be acceptable).

A related species of the greater and lesser argument is the right-privilege distinction. If a certain benefit is found to be a privilege, and not a right, then it may be denied entirely at the government's discretion. This greater power then justifies the imposition of conditions. Professor Van Alstyne's announcement of the demise of this right-privilege distinction, see Van Alstyne, The Demise of the Right-Privilege Distinction, 81 HARv. L. REv. 1439, 1458-64 (1968) [hereinafter cited as Van Alstyne, RightPrivilege Distinction]; see also Van Alstyne, The Constitutional Rights of Public Employees, 16 UCLA L. REv. 751, 754 n.14 (1969) [hereinafter cited as Van Alstyne, Public Employees], was more hopeful prediction than accomplished fact. The distinction has continued vitality. $C f$. Wyman v. James, 400 U.S. 309,319 (1971) (because welfare is a privilege, not a right, benefits may be conditioned on consent to home inspections).

14 See, e.g., South Dakota v. Neville, 103 S. Ct. 916 (1983) (power to require motorist to undergo breathalizer test includes lesser power to use refusal to take optional test as evidence against a criminal defendant); Texas v. White, 423 U.S. 67 
been attracted to the idea that when the government acts in a proprietary capacity, its conceded power to dispose of property includes the "lesser" power to restrict its use for selected first amendment activities. ${ }^{45} \mathrm{He}$ maintains, with decreasing success, that government's power to define the terms upon which benefits are offered includes the capacity to exclude due process protections. ${ }^{46}$ In a reincarnation of cases from over a hundred years ago, ${ }^{47}$ Justice Rehnquist argues that a state's right to prohibit business incorporation carries a concomitant right to permit incorporation only on the condition that it renounce first

(1975) (greater authority to search car at time of arrest justifies lesser infringement of warrantless search at police station); Chambers v. Maroney, 399 U.S. 42, 51 (1970) (authority to impound car justifies lesser intrusion of warrantless search).

45 See United States Postal Serv. v. Council of Greenburgh Civic Ass'ns, 453 U.S. 114,129 (1981) (proprietary power over mailboxes justifies exclusion of all unstamped mail); Jones v. North Carolina Prisoners' Labor Union, Inc., 433 U.S. 119, 125-26 (1977) (proprietary power over prisons includes power to prohibit prisoner unionization); Memorial Hosp. v. Maricopa County, 415 U.S. 250, 283 (1974) (Rehnquist, J., dissenting) (hospital management, unlike traditional government functions, is essentially the provision of a private facility on which government is free to impose limitations); see also Delta Air Lines v. August, 450 U.S. 346, 368 (1981) (Rehnquist, J., dissenting) (accusing majority of ignoring "common-sense maxim" that greater includes lesser).

Justice Rehnquist has not been alone. See, e.g., Metromedia, Inc. v. San Diego, 453 U.S. 490, 555 (1981) (Stevens, J., dissenting in part) (If a total ban on billboards is permissible, content neutral exceptions should be subject to lesser scrutiny.); Greer v. Spock, 424 U.S. 828 (1976) (Stewart, J., majority opinion) (arguing that government as property owner maj restrict first amendment rights on military base).

40 Justice Rehnquist first staked out this position in Arnett v. Kennedy, 416 U.S. 134, 153-54 (1974) (plurality opinion) (Claimants "must take the bitter with the sweet" by accepting whatever due process limitations accompany the provision of a benefit.). This approach appeared to have gained the support of a majority of the Court in Bishop v. Wood, 426 U.S. 341 (1976) (refusing to apply due process rights to the dismissal of a government employee). However, Justice Rehnquist has found himself increasingly among dissenters as the Court explicitly has rejected the proposition that the power to grant a benefit comprehends the power to define the procedures by which it may be denied. See, e.g., Logan v. Zimmerman Brush Co., 455 U.S. 422, 431-32 (1982) (applying due process requirements to government fair employment practices review); Vitek v. Jones, 445 U.S. 480, 490 n.6 (1980) (explicitly rejecting Arnett plurality); Matthews v. Eldridge, 424 U.S. 319 (1976) (scrutinizing procedures in Social Security statute for due process violations).

For the latest commentary on the interaction between the definition of property and the due process protections it entails, see Alexander, The Concept of Property in Private and Constitutional Law: The Ideology of the Scientific Turm in Legal Analysis, 82 Colum. L. Rev 1545 (1982); Easterbrook, Substance and Due Process, 1982 SuP. CT. REv. 85; Smolla, The Reemergence of the Right-Privilege Distinction in Constitutional Law: The Price of Protesting Too Much, 35 Stan. L. Rev. 69 (1982); Terrell, "Property," "Due Process," and the Distinction between Definition and Theory in Legal Analysis, 70 Gro. L.J. 861 (1982); Williams, Liberty and Property: The Problem of Govermment Benefits, 12 J. LEGAL STUD. 3 (1983).

17 On the efforts by states to condition the right of corporations to do business within their jurisdictions, see cases and sources included in supra note 30. 
amendment rights. ${ }^{48}$

On the other side of the aisle, in Federal Energy Regulatory Commission v. Mississippi ${ }^{49}$ [FERC], Justice Blackmun used the greater and lesser argument to defend federal action that allowed states to regulate natural gas only on the condition that they comply with federal requirements. "Congress could have pre-empted the field . . . [therefore, the statute] should not be invalid simply because, out of deference to state authority, Congress adopted a less intrusive scheme and allowed the States to continue regulating [on condition]." texts, the Court was unanimously receptive to the argument that the greater power of Indian tribes to exclude oil drilling included the lesser power to impose a severance tax ${ }^{51}$ and was unanimously perplexed by the proposal that there was a difference between removing books from a school library and not buying them in the first place. ${ }^{\mathbf{6 2}}$

The durability of the argument that the greater includes the lesser is a tribute to its prima facie intuitive appeal. Even defenders of the unconstitutional conditions doctrine have been apologetic in their criticism of the argument. Professor Hale commented that the "doctrine of unconstitutional conditions, as so stated, is difficult to support logically. If I have no ground for complaint at being denied a privilege absolutely, it is difficult to see how I acquire such a ground merely because the state . . offers me an alternative, however harsh."ss Such deference is unwarranted, for despite its distinguished lineage and superficial plausibility, the argument in defense of government's unbridled prerogative to condition allocations is deeply flawed.

First, for seventy-five years it has been clear that the argument that the greater includes the lesser does not work as syllogism. ${ }^{54}$ All

48 See First Nat'l Bank v. Belotti, 435 U.S. 765, 825-27 (1978) (Rehnquist, J., dissenting).

49456 U.S. 742 (1982).

so Id. at 765. Justice O'Connor strongly dissented in part in FERC, calling the greater and lesser argument an absurdity that would dissolve all constitutional limits on federal regulation of state action. See id. at 781 (O'Connor, J., concurring in part, dissenting in part). Last Term, however, Justice O'Connor relied on the greater and lesser argument to defend the admissibility of evidence of a drunk driver's refusal to take a blood alcohol level test. See South Dakota v. Neville, 103 S. Ct. 916, 923 (1983) (The "state could legitimately compel the suspect . . . to accede to the test . . . . [T] action becomes no less legitimate when the state offers a second option of refusing the test, with the attendant penalties .....").

${ }^{51}$ See Merrion v, Jicarilla Apache Tribe, 455 U.S. 130, 144, 159, 186 (1982).

62 See Board of Educ. v. Pico, 457 U.S. 853 (1982).

53 Hale, Unconstitutional Conditions and Constitutional Rights, 35 Colum. L. Rev. 321-22 (1935). See also Alschuler, The Changing Plea Bargaining Debate, 69 GaLIF. L. REv. 652, 699 (1981) ("There seems to be no direct and satisfying answer to the a fortiori logic of the old right/privilege distinction.").

84 Professor Powell dissects the argument as follows: 
that can be deduced logically from the power to deny a benefit absolutely is the power to deny it absolutely. If the power to deny conditionally is, by definition, subsumed in the power to deny absolutely, then the argument is valid, but trivial. If one does not accept the premise that the power of conditional denial is an element of the power of absolute denial, then the former cannot be deduced from the latter. But this alone does not disqualify the argument. The underlying question is whether the conditional denial is qualitatively different. Legal reasoning relies more on the persuasiveness of analogy than on the validity of a syllogism. ${ }^{\mathrm{bS}}$ Yet even as an analogy the argument is flawed.

Two defects are illustrated by Justice Holmes's explication that "the consequence is the measure of the condition" and the condition is legitimate when the only consequence of its breach is a result the state may bring about directly. First, the argument assumes that the only aspects of governmental action subject to review are its consequences.

[Justice Holmes] implies that the power of total exclusion is a "whole," of which the power to impose any burdens whatsoever on those admitted is a "part." The fallacy here will appear if the proposition is put in syllogistic form.

Major Premise. There is a class of corporations "A" . . over which the state has the power of absolute exclusion.

Minor Premise. The X corporation is an " $\mathrm{A}$ " corporation.

Conclusion. Therefore the $\mathrm{X}$ corporation is one upon which the state has power to impose any burden whatsoever.

Plainly the only legitimate conclusion is that the $\mathrm{X}$ corporation is one over which the state has the power of absolute exclusion. . . . [Justice Holmes] has a different predicate in his conclusion from that in his major premise. ... The "power of absolute exclusion" is a term not identical with the "power of relative exclusion" or the "power to impose any burdens whatsoever."

Powell, The Right to Work for the State, 16 CouvM. L. Rev. 99, 110-11 (1916) (footnotes omitted). See also French, supra note 30, at 239-42; O'Neil, Unconstitutional Conditions: Welfare Benefits with Strings Attached, 54 Calf. L. REv. 443, 461 (1966); Westen, Incredible Dilemmas: Conditioning One Constitutional Right on the Forfeiture of Another, 66 IowA L. REv. 741, 747 n.20 (1981).

Although these writers have demonstrated that the greater and lesser argument fails deductively, the argument is not left without any force; it may work inductively or as a persuasive analogy. Such forms of reasoning, though invalid in formal logic, predominate in legal and practical argument. See C. Perelman, Justice, Law and Argument 148-61 (1980) [hereinafter cited as C. Perelman, Law and ARgument]; cf. S. Handelman, The Slayers of Moses 52-57 (1982) (describing persuasive force of greater and lesser style argument in rabbinic thought; contrasting it with deductive syllogisms prevalent in Greek thought). See generally C. Perelman, The Idea of Justice and the Problem of Argument (1963) [hereinafter cited as C. PerelMAN, THE IDEA OF JUSTICE].

ss See C. Perelman, The Idea of Justice, supra note 54, at 156; Burton, Comment on Empty Ideas: Logical Positivist Analyses of Equality and Rules, 91 YALE L.J. 1136 (1982); Murray, The Role of Analogy in Legal Reasoning, 29 UCLA L. REV. 833 (1982); Christie, Book Review, 80 Mich. L. Rev. 715 (1982) (reviewing C. PERELMAN, LAW AND ARGUMENT, supra note 54). 
This assumption is misguided. Many, if not most, constitutional constraints on government concern not the consequences of its decisions, but the processes by which they are made. Not only the destination, but the path, is crucial in constitutional analysis. Whether a prisoner has been convicted in accordance with due process or as the result of a coerced confession, the consequence of imprisonment is identical, but it cannot be said that the Constitution is unconcerned with the method by which the result is achieved. For the broad class of cases where constitutional norms constrain the means by which government may achieve its ends, the argument of the greater and lesser is wholly inapplicable. ${ }^{\text {se }}$

A second shortcoming of Holmes's argument is its generally restricted interpretation of the scope of consequences to be evaluated. From one vantage, the consequence of excluding blacks from a swimming pool may be no different for those excluded than the consequence of closing the pool entirely. In neither case can blacks swim. Yet, a more realistic evaluation of the consequences recognizes that they differ in at least one dimension: the benefit extended to whites. Blacks in the latter case lack a claim of comparative injustice that blacks in the former case can assert. This may not be the only claim available, but it seems clear that being denied an advantage granted to others differs from being harmed in isolation. ${ }^{57}$ Likewise, the consequence of knowing that unemployment compensation will be denied a Seventh Day Adventist if she refuses to work on Saturday is significantly different from knowing that no unemployment compensation program exists. The "pressure upon her to forego [her] religion" is a consequence of the former situation that is absent in the latter. ${ }^{58}$

so See, e.g., Larkin v. Grendel's Den, Inc., 103 S. Ct. 505, 509-11 (1982) (state may limit or prohibit liquor license in proximity of churches and schools, but it may not delegate that power by giving churches a veto); $c f$. Textile Workers Union v. Lincoln Mills, 353 U.S. 448, 474 (1957) (Frankfurter, J., dissenting) (Constitution fixes allocation of decisionmaking authority; "Surely the truly technical restrictions of Article III are not met or respected by a beguiling phrase that the greater power here must necessarily include the lesser.").

${ }^{87}$ See also infra text accompanying notes 258-91. Compare Palmer v. Thompson, 403 U.S. 217 (1971) (closing rather than integrating public swimming pool does not violate equal protection clause) with Sweatt v. Painter, 339 U.S. 629, 634-35 (1950) (provision of separate state law school for blacks violates equal protection despite lack of obligation to provide legal education in the first place).

Although Professor Westen has argued that equality is an empty and misleading principle when divorced from any set of legal rights or values, he nevertheless finds some content in claims of comparative injustice. See Westen, The Empty Idea of Equality, 95 Harv. L. Rev. 537, 551-54 (1982); cf. B. ACKerman, Social Justice IN THE LiBERAL STATE 205-07 (1980) (A recipient may prefer to receive greater benefits on a condition of inequality that others be better off than he, rather than an absolute equality in which everyone, including the recipient, receives fewer benefits.).

ss Sherbert v. Verner, 374 U.S. 398, $403-04$ (1963); cf. O'Neil, supra note 54, at 
If, in evaluating consequences, attention is focused not simply on the denial of benefits, but on the state of the world after the denial, Justice Holmes's dictum that the consequence is the measure of the condition becomes not a pat defense for allocational sanctions, but a demanding test to scrutinize governmental action. It translates into the claim that an impact on constitutional rights is sufficient to invalidate an allocation. ${ }^{80}$

Justice Holmes's greater and lesser analogy has a more fundamental failing. Part of the argument's charm is its implicit assertion that the government is not aggrandizing its power. The government could have wielded the greater power of denying the benefit entirely, according to the argument, and therefore its more restricted exercise of that power, in the form of a conditional grant, gives the government no additional power. The difficulty with this position is its assumption that the government could have, in fact, wielded the greater power. ${ }^{60}$

Often it is only by ripping a problem from its historical context that selective denial can be viewed as a lesser power. ${ }^{61}$ In reality, selective deprivation may be the less controlled and hence the more dangerous power. In many situations, the government's absolute denial of a benefit is not practically or politically feasible, absent overwhelming public necessity. It is only this practical or political resistance that makes the government's possession of the greater power at all tolerable. Allowing the government to deny benefits to some, but not all, of the populace gives it a power that is nowhere implicit in the power to deny benefits absolutely. ${ }^{62}$ Conversely, the selective denial of a benefit may be more onerous to a population accustomed to the benefit than the failure to grant it in the first place.

The Townsend court recognized this in rejecting the inference that the legislature's power to set court terms authorized it to delay execu-

462 (psychological impact of conditioned benefit may be greater than that of absolute denial).

50 If the consequence is to be the measure of the constitutionality of the condition, then legislatures may not accomplish indirectly by conditioning privileges what they cannot accomplish directly by criminal sanctions. See infra text accompanying notes 164-97.

${ }^{60}$ See O'Neil, supra note 54, at 463-64 (questioning extent of greater power).

o1 Neither is it clear that a conditioned benefit is in any way a less potent sanction or a lesser power. Compelling psychological suasion or dire necessity for sustenance may render the withdrawal of a benefit highly coercive. See O'Neil, supra note 54, at 462, 471-73.

62 See, e.g., Minneapolis Star \& Tribune Co. v. Minnesota Comm'r of Revenue, 103 S. Ct. 1365, 1372 (1983) ("When the State singles out the press [for special taxation], though, the political constraints that prevent a legislature from passing crippling taxes of general applicability are weakened, and the threat of burdensome taxes becomes acute."). 
tion because a more selective denial would not arouse " $[\mathrm{t}]$ he indignant disapprobration of the people." ${ }^{\text {"8s }}$ Even Justice Holmes, at times, acknowledged the distinction. ${ }^{64}$ Nonetheless, sixty years later, judges continue to argue for the a fortiori permissibility of questionable government activities on the basis of the theoretical availability of alternative, and putatively greater, powers. ${ }^{65}$ Seductive arguments, however, are not necessarily sound. Unless these alternatives are practically available, the lesser exercise of selective denial can gain no support from hypothetically greater powers of absolute denial. Selective denial warrants recognition as a separate and potentially encroaching state power.

\section{Two Emerging Errors: Negative Rights in a Positive State}

The greater and lesser doctrine sees in the affinity between the concededly permissible greater power and the lesser power at issue a warrant for immunizing the lesser power from judicial review. Two lines of doctrine emerging from contemporary courts and commentators also insulate allocational sanctions from active review, but do so by focusing on particular reasons that the greater power is thought to be permissible.

The first doctrine defines the greater power as the power to control and dispose of property. A private individual may manage property as she sees fit, free of constitutional limitations. So too, runs this argument, the government's proprietary actions are not constitutionally

6s Townsend, 7 Tenn. at 15, Peck at 19.

6 Compare Justice Holmes's admission that habitual reliance on a benefit may justify constitutional protection in Leach v. Carlile, 258 U.S. 138, 141 (1922) (Holmes, J., dissenting) (If the government chooses to offer postal service, it may do so on condition, "which is well enough when neither law nor the habit that the Government's action has generated has made that means the only one. But when habit and law combine to exclude every other it seems to me that the First Amendment in terms forbids such control of the post.") with Justice Holmes's more usual attitude in City and County of Denver v. Denver Union Water Co., 246 U.S. 178, 197 (1918) (Holmes, J., dissenting) (arguing that because city could theoretically require water company to remove its pipes from the city's streets, it may set water rates at a level that does not permit a fair return on the water company's investment).

${ }^{63}$ See, e.g., FERC v. Mississippi, 456 .U.S. 742, 765-67 (1982) (federal government may preempt state utilities regulation; therefore, it may impose requirements); United States Postal Serv. v. Council of Greenburgh Givic Ass'ns, 453 U.S. 114, 12627 \& n.5 (1981) (government may abandon postal service altogether; therefore, it may attach conditions and restrictions). The Court, at times, has acknowledged the extreme improbability that the government would exercise its putatively greater power, although not admitting this to be a weakness in the greater-lesser argument. See, e.g., $F E R C, 456$ U.S. at 767 (unlikely that states would abandon utilities regulation to federal government); City and County of Denver v. Denver Union Water Co., 246 U.S. 178, 197 (1918) (Holmes, J., dissenting) (admitting city's greater power of ordering water company to remove its pipes from the streets was merely theoretical). 
constrained.

Several members of the Supreme Court seem increasingly attracted to this distinction between proprietary and sovereign governmental activities. While sovereign activity is subject to constitutional constraint, the government in its proprietary persona is as free, or almost as free, as a private proprietor in disposing of its property. If one of the most effective means of social control at the disposal of a modern government is the allocation of benefits, ${ }^{86}$ then this proprietary/sovereign distinction portends the disintegration of constitutional review. Careful analysis suggests, however, that nothing in the government's role as proprietor warrants such deference.

A second doctrine draws from liberal political philosophy. It explains the results of the cases by viewing constitutional liberties as negative rather than positive freedoms. Negative freedoms require only that a government not interfere in their exercise. A government that simply refuses to extend a benefit is passive and has no obligation to do more. Distinguishing action from inaction is appealing, but misguided. The line between nonfeasance and misfeasance is theoretically problematic and difficult to maintain.

\section{a. The Sovereign/Proprietary Distinction}

Having a constitutional right to perform a given act means, at least, that one may perform that act without governmental interference. ${ }^{87}$ The problem, however, is to define "interference." The task of constitutional law may be to identify a limited set of impermissible sanctions that abridge constitutionally protected rights and that therefore may be labeled as interferences. Application of a sanction from outside that set of interferences would not violate the right in question. ${ }^{68}$ And, for one contemporary position, the set of sanctions that can

So Supra notes 2-8 and accompanying text.

67 This approach toward constitutional protections is in accord with those theories of freedom that define it as freedom from constraints on, or barriers to, potential human endeavors. As Isaiah Berlin characterizes it, "freedom . . . entails . . . the absence of obstacles to possible choices and activities-absence of obstructions on roads along which a man can decide to walk." I. BerLIN, Four EsSAYS ON LIBERTY xxxixxl (1969). Accord, e.g., J. RawLS, A TheORY of Justice 202 (1971).

If this is so, disagreements regarding negative and positive liberty are not disagreements about some fundamental difference. They are merely differences regarding the range of agents, preventing conditions and actions involved in the statement " $x$ is (is not) free from $y$ to do (not do, become, not become) z." See MacCallum, Negative and Positive Freedom, 76 PHIL. REv. 312 (1967).

o8 This is distinct from a theory that, in certain circumstances, government's proprietary interests may be invoked to justify a prima facie infringement of constitutional rights. See, e.g., Wells \& Hellerstein, The Governmental-Proprietary Distinction in Constitutional Law, 66 VA. L. Rev. 1073, 1113-21 (1980). If allocational sanctions do 
impinge on constitutional rights does not include sanctions invoked by the government in its proprietary capacity. This seems to be the thrust of Justice Powell's comment in Maher $v$. Roe. ${ }^{69}$

There is a basic difference between direct state interference with a protected activity and state encouragement of an alternative activity consonant with legislative policy. Constitutional concerns are greatest when the State attempts to impose its will by force of law; the State's power to encourage actions deemed to be in the public interest is necessarily far broader. ${ }^{70}$

Similarly, for Justice Rehnquist only sovereign interference is forbidden interference. ${ }^{71}$

This thinking has surfaced in other areas. It has appeared elsewhere in Justice Powell's decisions, as a suggestion that relations between state and citizen should be subject to less stringent requirements when the state plays a "private" role. ${ }^{72}$ Justice Rehnquist has been an indefatigable exponent of the position that "the role of government as sovereign is subject to more stringent limitations than is its role of government as employer, property owner or educator.""3s And Justice

not even call into play demands for constitutional justification, then the strength of the government's justification for those sanctions is irrelevant.

69432 U.S. 464 (1977).

${ }^{70}$ Id. at 475-76 (footnote omitted), quoted in Harris v. McRae, 448 U.S. 297, 315 (1980). It is possible to read Justice Powell as distinguishing not between sovereign and proprietary actions, but between actions that discourage and those that encourage. For a discussion of the distinction between offers and threats, see infra text accompanying notes 220-42.

71 See, e.g., Regan v. Taxation with Representation, 103 S. Ct. 1997, 2002-03 (1983) (quoting Maher v. Roe) ("Congressional selection of particular entities or persons for entitlement . . . is obviously a matter of policy and discretion not open to judicial review unless in circumstances which here we are not able to find." ") (quoting Cincinatti Soap Co. v. United States, 301 U.S. 308, 317 (1937)).

${ }_{72}$ See, e.g., Polk County v. Dodson, 454 U.S. 312, 318 (1981) (Powell, J.) (public defender's malpractice not state action where her "functions and obligations [are] in no way dependent on state authority," and relationship with plaintiff was "identical to that existing between any other lawyer and client'); Brown v. Glines, 444 U.S. 348, 356 n.13 (1980) (Powell, J.) (government as employer authorized to impose speech restrictions "reasonably necessary to promote effective government" in contrast to higher standards generally imposed); Greer v. Spock, 424 U.S. 828, 836 (1976) (Stewart, J.) ("The State, no less than a private owner of property, has the power to preserve the property under its control for the use to which it is lawfully dedicated." ") (quoting Adderley v. Florida, 385 U.S. 39, 47 (1966)); $c f$. Snepp v. United States, 444 U.S. 507, 509 n.3 (1980) (per curiam) ("[T]he .... GIA [may] protect substantial government interests by imposing reasonable restrictions on employee activities that in other contexts might be protected by the "First Amendment.").

${ }^{7 s}$ Board of Educ. v. Pico, 457 U.S. 853, 908-10 (1982) (Rehnquist, J., dissenting). Justice Rehnquist first established this position in Healy v. James, 408 U.S. 169, 203 (1972) (Rehnquist, J., concurring). For subsequent expressions in this vein by 
Blackmun seemed attracted to the notion during his early years on the Court. ${ }^{74}$

Nonetheless, the bulk of modern cases quite properly rejects this line of argument. ${ }^{25}$ However plausible at first glance, the sovereign/

Rehnquist, see Rehnquist, The First Amendment: Freedom, Philosophy, and the Law, 12 GoNZ. L. REv. 1, 10-12 (1976) (suggesting separate categories for government as employer and as property owner); see also United States Postal Serv. v. Council of Greenburgh Givil Ass'ns, 453 U.S. 114, 129-30 (1981); Southeastern Promotions, Ltd. v. Conrad, 420 U.S. 546, 571 (1975) (Rehnquist, J., dissenting) (lowered scrutiny of a refusal to allow "Hair" to play in a municipal auditorium because "[h]ere we deal with municipal action by the City of Chattanooga, not prohibiting or penalizing the expression of views in dramatic form by citizens at large, but rather managing its municipal auditorium"); Memorial Hosp. v. Maricopa County, 415 U.S. 250, 283 (1974) (Rehnquist, J., dissenting) (stating that refusal of medical care to indigent immigrants was permissible because "mere entry into the State does not invoke criminal penalties").

Justice Rehnquist repeated the point more explicitly in Buckley v. Valeo, 424 U.S. 1, 290-91 (1976) (Rehnquist, J., concurring in part, dissenting in part):

The limits imposed by the First and Fourteenth Amendments on governmental action may vary in their stringency depending on the capacity in which the government is acting. . . [ [G]ases which deal with the government as employer or proprietor are not fungible with those which deal with the government as a lawmaker enacting criminal statutes applying to the population generally.

Last Term, these views resurfaced. See, e.g., Regan v. Taxation with Representation, 103 S. Ct. 1997, 2000-02 (1983) (taxing power subject to less constitutional restriction than criminal statutes).

${ }^{74}$ See, e.g., Lehman v. City of Shaker Heights, 418 U.S. 298, 303 (1974) (exempting government policy limiting announcements on bus billboards from full first amendment scrutiny because it is "part of [a] commercial venture"); Wyman v. James, 400 U.S. 309, 317 (1971) (defending a requirement of home visits to welfare recipients against fourth amendment attack because "the visitation in itself is not forced or compelled, and . . . the beneficiary's denial of permission is not a criminal act"). Professor Smolla also takes this position. See Smolla, supra note 46, at 112-15.

Justice White, on occasion, has expressed the opinion that the government has greater leeway as an employer than as a regulator. See, e.g., Connick v. Myers, 103 S. Ct. 1684, 1689-90 (1983); United States Civil Serv. Comm'n v. National Ass'n of Letter Carriers, 413 U.S. 548, 556 (1973). Justice White has adopted a similar stance when the government acts as a property owner. See, e.g., Perry Educ. Ass'n v. Perry Local Educators' Ass'n, 103 S. Ct. 948, 958 (1983); cf. Southeastern Promotions, 420 U.S. at 567-69 (White, J., dissenting). Both Justices White and Blackmun, however, have expressed serious reservations about the sovereign/proprietary distinction. In dissent from an opinion upholding a regulation requiring that at least half of the workforce on city funded construction projects be local residents, Justices White and Blackmun argued that the effect would be "virtually identical to the effect of a conventional market regulation" and expressed concern about "using the tremendous power of the state treasury directly to impede the free flow of . . . commerce." White v. Massachusetts Council of Constr. Employers, Inc., 103 S. Ct. 1042, 1048-54 (1983) (Blackmun \& White, JJ., concurring in part and dissenting in part). The Court seems to be moving toward agreement with these reservations. Recently, an identical statute was held to be subject to invalidation as violating the privileges and immunities clause. See United Bldg. \& Constr. Trades Council v. Camden, 52 U.S.L.W. 4187 (U.S. Feb. 21, 1984) (No. 81-2110).

${ }_{75}$ For a discussion of cases decided through the mid-1960's that rejected this sovereign/proprietary distinction, see Linde, Constitutional Rights in the Public Sector: 
proprietary distinction proves on examination to be, at best, obscure. ${ }^{78}$

The government as proprietor is no less dangerous to liberty than as sovereign. While there is a contemporary philosophical school that attaches unique status to rights of bodily integrity and freedom from physical force, ${ }^{77}$ it is hard to imagine any modern constitutional theorist taking the position that only a direct threat of violence would violate constitutional rights. The Court has long recognized that fines may deter no less thoroughly than the threat of prison and taxes no less effectively than fines. ${ }^{78}$ From this recognition, it is only a short step to acknowledging that the deprivation of a monetary benefit by the government acting in its proprietary capacity may be an equally effective deterrent.

Revocation of access to the U.S. mails, for example, would more effectively silence a dissident news magazine than either a fine or a

Justice Douglas on Liberty in the Welfare State, 40 WASH. L. REv. 10 (1965); Van Alstyne, Right-Privilege Distinction, supra note 43 . The rejection of this distinction has continued in recent cases. See, e.g., Zobel v. Williams, 457 U.S. 55 (1982) (conditions on interstate travel); Widmar v. Vincent, 454 U.S. 263 (1981) (conditions on use of state university); Branti v. Finkel, 445 U.S. 507 (1980) (conditions on government employment); McDaniel v. Paty, 435 U.S. 618 (1978) (conditions on public office); Lefkowitz v. Turley, 414 U.S. 70 (1973) (conditions on government contracts); Bond v. Floyd, 385 U.S. 116 (1966) (conditions on admission to legislature).

${ }_{76}$ See Owen v. City of Independence, 445 U.S. 622, 644 n.26 (1980) (Referring to the non-governmental/governmental quagmire, the Court stated, "A comparative study of the cases in the forty-eight states will disclose an irreconcilable conflict. More than that, the decisions in each of the States are disharmonious, and disclose the inevitable chaos when courts try to apply a rule of law that is inherently unsound." ") (quoting Indian Towing Co. v. United States, 350 U.S. 61, 65 (1955) (on rehearing)); Wells \& Hellerstein, supra note 68, at 1136 ("The terms 'governmental' and 'proprietary' are best viewed as labels expressing the conclusion that particular legal government activity should be accorded a particular legal status and not as standards to be used in reaching such a conclusion.").

77 See C. Fried, Right and Wrong 30-32 (1978); R. Nozick, ANarchy, STATE, AND UTOPIA 32-33 (1974) ("Political philosophy is concerned only with certain ways that persons may not use others; primarily physically aggressing against them . . . . This root idea [of human dignity] . . . leads to a libertarian side constraint that prohibits aggression against another."); Epstein, Causation and Corrective Justice: A Reply to Two Critics, 8 J. Legal STUD. 477 (1979) (natural right of liberty understood as "freedom from force and falsehood"); Epstein, A Theory of Strict Liability, 2 J. Legal Stud. 151 (1973); $c f$. T. HobBes, Leviathan chs. 14, 21 (rev'd Amer. ed. 1950) (Liberty is "freedom from chains and prison" or absence of "external impediments to motion.").

${ }_{78}$ See Minneapolis Star \& Tribune Co. v. Minnesota Comm'r of Revenue, 103 S. Ct. 1365, 1372 (1983) (threat of burdensome and selective tax may effectively censor freedom of the press); Grosjean v. American Press Co., 297 U.S. 233, 245-48 (1936) (holding newspaper revenue tax invalid and recounting historical instances of censorship through taxation of press); Lipke v. Lederer, 259 U.S. 557, 561-62 (1922) (tax on sale of liquor found to be penalty to enforce prohibition); Bailey v. Drexel Furniture Co. (Child Labor Tax Case), 259 U.S. 20, 36-37 (1922) (tax on interstate trade in products of child labor found to be penalty for employment of children beyond authority of Congress). 
prison sentence for the editor. Even a revocation of subsidized second class mail rates could be as effective. ${ }^{79}$ And an employee who cheerfully risks a misdemeanor conviction by asserting her free speech rights might be reluctant to hazard her pension in a similar cause.

If the effectiveness of the deterrents available to government is at issue, then there is no a priori reason that sovereignty should equate with danger. Indeed, the converse may be true. The effectiveness of any sanction will be a function of both its magnitude, and its ease of implementation. Not only is the magnitude of proprietary sanctions often greater than of sovereign ones, but they are often much more easily brought to bear. A government that employs criminal sanctions must first find the violators, then prosecute them. On the other hand, recipients of benefits must themselves come to government on a regular basis. ${ }^{80}$ Sanctions can be applied through administrative mechanisms already in place. Limitations attached to allocational sanctions need not be drawn with the narrow specificity of criminal statutes, and in most cases, sanctions may be applied with only a fraction of the due process protections required in criminal prosecutions. In short, the government that encourages nonexercise of constitutional rights by using allocational sanctions may be quite as dangerous as the government that "attempts to impose its will by force of law."81

Arguments about the relative forcefulness of criminal and allocational sanctions may, however, miss the point. Most constitutional theorists would agree that a $\$ 10$ fine for criticizing the President is no more constitutional than a $\$ 10,000$ fine or a ten-year prison sentence. So, too,

79 See United States ex rel. Milwaukee Soc. Democratic Publishing Co. v. Burleson, 255 U.S. 407, 434-35 (1921) (Brandeis, J., dissenting) (Revocation of second class mail privilege is "in effect a very heavy fine."); of. Hannegan v. Esquire, Inc., 327 U.S. 146, 156 (1946) (Denial of second class mail rate implicates constitutional rights.)

${ }^{80}$ See, e.g., Wyman v. James, 400 U.S. 309 (1971) (conditioning welfare payments on consent to home inspections); see supra note 8.

${ }^{81}$ Maher, 432 U.S. at 476. Similarly, one may claim that private competition serves to limit proprietary governmental actions in ways that make them less dangerous than sovereign actions. See, e.g., Smolla, supra note 46, at 115-16. This is plausible only in limited circumstances. Even in a perfect market, a government willing to expend sufficient tax-generated resources could effectively purchase most constitutional rights. Given substantial (or even minimal) market failures, the claim that private competition will check government excesses becomes weaker still. In many cases the government has a legal monopoly (e.g., postal services) or a strong oligopolistic position (e.g., school textbooks or aerospace engineers). Even in competitive situations, market discipline will often be lacking. If hostility to the exercise of a constitutional right is widely felt, the private sector will not provide much of a check on government. McCarthy era blacklists, for example, are hardly reassuring instances of the private stewardship of constitutional rights in a free market. Similarly, if only a minority of beneficiaries value some constitutional rights, the private sector may not find efforts to establish a competitive service to be worthwhile. 
a government offer of $\$ 5$ million to run an advertisement in the public interest violates no rights of the newspaper that receives it. ${ }^{82}$ The issue is not the magnitude of the incentives that the government may bring to bear, but their nature.

One might argue that government's actions in its proprietary capacity are, by nature, intrinsically less offensive to constitutional norms than are actions in its sovereign capacity. Enforcement of a criminal statute requires direct invocation of the government's monopoly on coercive violence-a monopoly requiring special control. Similarly, behind the tax collector stands the armed might of the state. On the other hand, one might argue, a public university-one manifestation of the state as proprietor-has no greater power at its disposal than any other property owner; like the corner grocer, it hires and fires its employees. ${ }^{83}$

This defense, however, collapses on examination, for the tax collector also stands behind the university. No public enterprise, however proprietary, can claim the same genealogy as a private enterprise. Somewhere along the line it rests on the sovereign taxing power, and it cannot plausibly claim to be the unsullied product of freely adopted private choices. ${ }^{84}$

82 Freedom of the press may not be the only reason why government should be constitutionally constrained from issuing advertisements. Should the advertisements contain racial slander, for example, or should the government seek to inhibit rights considered inalienable, they might be opposed on other grounds. $C f$. infra text accompanying notes 333-64.

${ }_{\text {8s }}$ Cf. Connick v. Myers, 103 S. Ct. 1684, 1690 (1983) ("[O]rdinary dismissals from government service which violate no fixed tenure or applicable statute or regulation are not subject to judicial review."). It is no longer clear that private parties are altogether free from constraint. Courts have begun to grant causes of action to employees discharged from private employment without good cause. See, e.g., Novosel v. Nationwide Ins. Co., No. 82-1600 (3d Cir. Oct. 26, 1983) (employee discharged for refusing to help employer's political cause); Bomar v. Keyes, 162 F.2d 136 (2d Gir. 1947) (teacher dismissed for serving on jury), cert. denied, 332 U.S. 825 (1947), Monge v. Beebe Rubber Co., 114 N.H. 130, 316 A.2d 549 (1974). See generally Note, Protecting At Will Employees Against Wrongful Discharge: The Duty to Terminate Only in Good Faith, 93 HARV. L. REV. 1816 (1980).

B4 The normative justification that private property simply represents the result of combining free private choices with natural attributes of personality is unavailable when the property is obtained through the taxing power.

In an ideal free market economy, more resources should accrue to those who more efficiently produce desirable goods and services. There is, therefore, a widely discussed efficiency justification for the ordering of economic power that results from private action. No such claim can be made for aggregations of capital formed through government's power to tax and appropriate funds.

Moreover, the efficiency argument merely justifies the existence of some property rights, not of a particular distribution scheme that vests particular rights in the government. It provides more plausible support for the sovereign/proprietary distinction that has recently gained currency in commerce clause litigation. See, e.g., White v. Massachusetts Council of Constr. Employers, Inc., 103 S. Ct. 1042, 1048 (1983); Reeves, Inc. 
The tenuousness of the proprietary/sovereign distinction is welldemonstrated by a recent opinion by the foremost contemporary proponent of the distinction: Justice Rehnquist. In United States Postal Service v. Council of Greenburgh Civic Associations, ${ }^{85}$ the Court upheld a federal statute making it a crime to deposit unstamped material in a mailbox that received mail from the post office. The statute was challenged as an unconstitutional limitation on freedom of speech by a community organization that wished to leave its newsletter in the mailboxes of its members.

In disposing of that claim, Justice Rehnquist relied on the maxim that " $t]$ he state, no less than a private owner of property, has power to preserve the property under its control for the use to which it is lawfully dedicated." ${ }^{\prime 86}$ A private owner may lock her mailbox to exclude unwanted mail, therefore, the government may do likewise. With a singular lack of imagination, Justice Rehnquist proclaimed, "[I]t is difficult to conceive of any reason why this Court should treat a letterbox differently . . than it has in the past treated the military base . . . the

v. Stake, 447 U.S. 429, $436-37$ (1980); Hughes v. Alexandria Scrap Corp., 426 U.S. $794,809-10$ (1976). If one believes that, as an historical matter, the commerce clause was not designed to limit state economic enterprises or that the proper and efficient functioning of national markets requires a lack of constraints on market participants, the distinction may make some sense. The economy responds relatively smoothly to alterations in demand and supply conditions manifested by market participants. On the other hand, flat prohibitions by a government acting as sovereign may generate greater disruption. Likewise, there may be a sound policy reason for attempting to ensure that states are not placed at a competitive disadvantage.

Even in the commerce clause area, the Court apparently does not take the position that the state's proprietary machinations are without constitutional limit. See White, $103 \mathrm{~S}$. Ct. at $1046 \mathrm{n.7}$ ("[T]here are some limits on a state or local government's ability to impose restrictions that reach beyond the immediate parties with which the government transacts business."). Even for immediate participation, moreover, it seems inconceivable that a state that has socialized its telephone service may discriminate against out of state businesses seeking to conduct interstate commerce. And here too, cracks are beginning to appear in the proprietor/sovereign distinction. Having exempted the residency requirement for contractors' employees from scrutiny in White, the Court reversed direction in United BIdg. \& Constr. Trades Council v. Camden, 52 U.S.L.W. 4187, 4191 (U.S. Feb. 21, 1984) (No. 81-2110) ("[T]he fact that Gamden [with an identical requirement] is merely setting conditions on its expenditures for goods and services in the marketplace does not preclude the possibility that those conditions violate the Privileges and Immunities Clause.").

There is instruction to be gained from the fact the current doctrine also permits discrimination against aliens in sovereign employment while banning it in the case of economic state actions. Two generations earlier, the doctrine had permitted discrimination in "distribution or regulation of the public domain" but not in sovereign actions intervening in the market. See Cabell v. Chavez-Salido, 454 U.S. 432, 436-41 (1982).

85453 U.S. 114 (1981).

${ }^{86}$ Id. at 129-30 (quoting Greer v. Spock, 424 U.S. 828, 836 (1976) (citing Adderley v. Florida, 385 U.S. 39 (1966)). 
jail or [the] prison."87

One reason, which Rehnquist chose not to conceive of, for treating letterboxes differently was that the post office neither owned nor locked the boxes in question. If the proprietary/sovereign distinction was determinative, the crucial element should have been the lack of any governmental proprietary interest. But the government did not buy exclusive access to the boxes. Instead, it made it a crime to deposit unstamped mail-a quintessentially sovereign act. The statute did, of course, achieve the same effect: no one stuffed the boxes with unstamped mail. This equivalence of effect is not surprising. It is no new insight that property rights, no less than tax liabilities, ultimately rest on the threat or application of coercive violence. ${ }^{88}$

What is remarkable is Justice Rehnquist's further claim that the government's action should be held to a lower standard of constitutional review because the state is merely acting like an owner of private property. Justice Rehnquist runs the Shelley $v$. Kraemer ${ }^{89}$ principle in reverse, transmogrifying a criminal statute into an exercise of proprietary power. This effectively demonstrates the identity of sovereign and proprietary power, but, absent some ground for distinguishing the two, it would seem to demonstrate that both powers should be constrained identically. ${ }^{90}$

Modern claims of legitimacy for property rights rest either on a theory of private appropriation that legitimates the invocation of force $e^{01}$ or on a desire to establish centers of choice independent of the government. ${ }^{82}$ Neither of these theories support any immunity of proprietary

87453 U.S. at 129 (citations omitted).

88 See, e.g., B. ACKERMAN, supra note 57, at 19; M. WEBER, MAX WEBER ON LAW IN ECONOMY AND SOCIETY 188-201 (M. Reinstein \& E. Shils, ed. \& trans. 1954); Cohen, The Basis of Contract, 46 Harv. L. Rev. 553 (1933); Cohen, Property and Sovereignty, 13 CorNell L.Q. 8 (1927); Hale, Force and the State: A Comparison of "Political" and "Economic" Compulsion, 35 Colum. L. Rev. 149 (1935); Hale, Coercion and Distribution in a Supposedly Non-Coercive State, 38 PoL. ScI. Q. 470 (1923); Mensch, Book Review, Freedom of Contract as Ideology, 33 STAN. L. REv. 753, 763 (1981).

88334 U.S. 1 (1948).

90 See infra text accompanying notes 329-32 for a discussion of the imaginative treatment of waiver in the case. The reverse manipulation is also possible. For example, in Buckley v. Valeo, 424 U.S. 1, 290-94 (1975) (Justice Rehnquist, concurring in part and dissenting in part), Justice Rehnquist began by distinguishing the proprietary from the sovereign power. He then classified the federal campaign statute at issue, which allocated federal funds to major political party election campaigns, as a sovereign act of Congress. Despite the fact that Congress was merely allocating subsidies, the statute was placed in a position where it was "most vulnerable to First Amendment attacks" because it was adopted "with a view to the regulation of the citizenry as a whole."

${ }^{91}$ R. Nozick, supra note 77 , at 149-82.

92 Private property is argued to be an important shield for individual autonomy 
government action from countermajoritarian constitutional guaranties of autonomy. Thus, the government as property owner stands on no higher footing than the government as sovereign, for the former cannot exist without invoking the latter. ${ }^{93}$ There is no particular reason to consider any exercise of economic power that infringes constitutionally protected interests with anything but a jaundiced eye.

A final oblique support for the proprietary/sovereign distinction is the suggestion reiterated by Justice Rehnquist that proprietary power is less problematic because it is not imposed on all citizens; ${ }^{94}$ criminal and regulatory powers, being broader, are more subject to abuse. There is an element of empirical truth to this assertion. Those who can be compelled by any given allocational sanction are fewer in number than those who can be affected by any given criminal control. Every citizen stands at risk should she choose to violate a criminal statute, but only recipients of government benefits can be coerced by allocative sanctions.

This difference, however, is hardly comforting, for allocational sanctions affect a sizable proportion of the population. ${ }^{95}$ Equally important, this formal distinction may make the allocational power even more dangerous, for it enables the government to circumvent more easily the virtual representation guaranties of the Constitution. ${ }^{86}$ By limiting allocative sanctions to particular benefit programs, the government can tailor its inducements to forego constitutional rights so they affect only the least popular or politically efficacious groups. It would probably raise equal protection difficulties to pass a statute taxing only indigent women who undergo abortions. By attaching conditions to a bene-

and as a check on government's powers. See A. OKun, EQUALITY AND EFFICIENCy 3839 (1975); Alexander, The Concept of Property in Private and Constitutional Law: The Ideology of the Scientific Turn in Legal Analysis, 82 Colum. L. REv. 1545, 159496 (1982); Brewster, The Corporation and Economic Federalism, in THE CoRPoraTION IN MODERN Society 72 (E. Mason ed. 1970); Reich, The New Property, 73 YALE L.J. 733, 764-68 (1964).

${ }^{93}$ Although it is not clear that he has proved to be descriptively accurate, Professor Linde was surely right as a normative matter in commenting that "[f]ar from giving government greater discretion, public ownership carries into the management of property the constitutional restraints that bind government generally." Linde, Constitutional Rights in the Public Sector: Justice Douglas on Liberty in the Welfare State, 40 WASH. L. REv. 10, 42 (1965).

of See Buckley v. Valeo, 424 U.S. 1, 291 (1975) (Rehnquist, J., concurring in part, dissenting in part); Healy v. James, 408 U.S. 169, 201-03 (1972) (Rehnquist, J., concurring).

${ }^{25}$ See Wyman v. James, 400 U.S. 309, 327 (1971) (Douglas, J., dissenting) (noting that in 1969 alone approximately $\$ 127$ billion was spent on social welfare payments and that recipients constituted a significant percentage of the population); see also supra notes 5-7.

os See J. Ely, Democracy and Distrust (1980). If the majority of citizens have no desire to engage in the particular activity, then virtual representation is not especially helpful. 
fit program used only by indigents, Congress was able to achieve the same result without quite so obvious a discrimination. ${ }^{97}$

\section{b. Positive and Negative Rights: The Problematic Distinction Between Action and Inaction}

\section{A second strand of recent analysis claims that constitutional liber- ties are concerned with negative rather than positive freedoms. ${ }^{98} \mathrm{~A}$ con-}

${ }^{87}$ Cf. Clements v. Fashing, 457 U.S. 957 (1982) (upholding statute requiring public office holders to resign in order to run for legislative office; those legislators who passed the statute were not included in the requirement).

${ }^{88}$ The most extensive and scholarly articulation of the implications of the negative and positive rights thesis for allocational sanctions is Appleton, Beyond the Limits of Reproductive Choice: The Contributions of the Abortion-Funding Cases to Fundamental-Rights Analysis and to the Welfare-Rights Thesis, 81 Colum. L. REv. 721, 754 (1981). Professor Appleton relies on previous work by Professor Charles Fried, but Professor Appleton's reliance on Professor Fried's distinction between positive and negative rights is probably misplaced. Professor Fried defines a positive right as a claim to some share of scarce goods, while a negative right is defined "as the right not to be wronged intentionally in some specified way." C. FRIED, RIGHT AND WRONG 110-12 (1978). Under this formulation, a withholding of benefits may be a violation of both negative and positive rights. In giving the example of a government that withholds police protection from a disfavored rally, Professor Fried notes that this could be characterized as both an intentional omission and as a violation of negative rights.

So long as there is a right to any call for protection at all, whatever basis a government may have for limiting that affirmative claim upon it for protection, one basis which it may not use is its desire to restrict the speech of the claimant. The illegitimacy of this basis for apportioning of the scarce resource has its ground in the negative right against the government.

Id. at $112 \mathrm{n} . *$.

Professor Fried's distinction is grounded in his conception that a "moral" right must, of necessity, be categorical and indefeasible. Absolute positive rights would inevitably conflict with each other, while absolute negative rights would not. Given that constitutional rights need not be absolute, it is not clear why the distinction should be transplanted from the moral into the legal sphere.

The distinction between positive and negative liberty offered by Isaiah Berlin also provides no grounds for exempting allocational sanctions from scrutiny. For Berlin, "negative liberty" addresses the question "How far does government interfere with me?" while "positive liberty" responds to the question "By whom am I ruled?" I. BERLIN, Two Concepts of Liberty, in Four Essays ON LIBERTY 130 (1969). Serious doubts have been expressed about the viability of Professor Berlin's distinction. See, e.g., C.B. Macpherson, Berlin's Division of Liberty, in Democratic Theory: EsSays IN Retrieval 95 (1973); MacCallum, Negative and Positive Freedom, 76 PHIL. REV. 312 (1967).

Apart from these more general problems, however, Berlin's definition of negative liberty includes the failure to open doors or possibilities for choice because of deliberate human action. See I. BERLIN, supra, at 130 n.1, 122-23, xl, xlvii,-xlvii. This definition undermines any attempt to separate positive from negative rights in the context of government's allocations of resources; even in demands for the most positive of governmental actions, the failure to open an opportunity is exactly what is complained of. Nor is Berlin's occasional distinction between liberty and "the conditions for its exercise," see $i d$. at lii-liv, any more helpful; it is both inconsistent and mechanical. See C.B. MACPHERSON, supra, at 102-04. 
stitutional right is said to be a mandate that the government not act to interfere with its citizens. Merely declining to confer a benefit is inaction that would not constitute a violation of constitutional rights. The rightholder retains the option of exercising the right free of affirmative opposition, and government is under no obligation to lend its assistance.

As it stands, the distinction is far too coarse to capture the reality of allocational sanctions. For example, when the government refuses first class mailing privileges to a publication that has criticized the president, it could be said that the government has merely declined to confer a benefit rather than affirmatively interfered with publication.99 Yet it is implausible that such inaction would not violate the first amendment. ${ }^{100}$ So too, a state that denies a foreign corporation a business license as retaliation for the corporation's exercise of its right to remove a case to federal court may be described as actively interfering with the corporation's business or as only passively declining to grant a license. ${ }^{101} \mathrm{~A}$ school that removes a book from its library may simply be ending its active provision of the book, or it may be affirmatively reducing the range of information previously available to students. ${ }^{102}$

This distinction between action and inaction is notoriously difficult to make, ${ }^{103}$ yet, it is central to contemporary efforts to distinguish between positive and negative rights. Absent strong conceptual underpinnings, the distinction is neither robust nor useful. Appropriate verbal manipulations can easily move most cases across the line. By definition, in the case of allocational sanctions, the government is both acting to

Professor Clark, at certain points, seems to espouse a similar distinction, which he bases on the difficulty of ascertaining the motives for inaction, and he offers the rather tautological comment that the Constitution limits governmental rather than private action. See Clark, Legislative Motivation and Fundamental Rights in Constitutional Law, 15 SAN Diego L. Rev. 953, 1014-16 (1978). Elsewhere in the article, however, he interprets "action" as those governmental activities or inactivities that alter the status quo ante. $I d$. at 1018 . While this approaches one appropriate analysis, see text accompanying notes $243-57$, it cannot be interpreted as a "mere" application of the distinction between private and state conduct.

99 Cf. Hannegan v. Esquire, Inc., 327 U.S. 146, 156-58 (1946) (withdrawal of second class postage permit infringes first amendment).

100 See id.

101 See supra note 30 and accompanying text.

102 Cf. Board of Educ. v. Pico, 457 U.S. 853 (1982).

${ }^{103}$ Cf. Rochester Tel. Corp. v. United States, 307 U.S. 125 (1939) (Frankfurter, J.). According to Frankfurter,

'Negative' has really been an obfuscating adjective in that it implied a search for a distinction-non-action as against action-which does not involve the real considerations on which rest [the decisions at issue]. 'Negative' and 'affirmative,' in the context of these problems, is as unilluminating and mischief-making a distinction as the outmoded line between 'nonfeasance' and 'misfeasance.'"

Id. at 141-42 (footnotes omitted). 
provide resources to one claimant and passively declining to provide resources to others.

In the era of Lochner $v$. New York, ${ }^{104}$ when states were thought to be limited to acting within clearly discernible boundaries, it may have been possible to distinguish state action that hindered the exercise of constitutional rights from action that exceeded those boundaries and affirmatively promoted such rights.

Denial of the protection of or access to courts because of the exercise of a constitutional right would easily be construed as a violation of negative constraints. Conversely, in matters outside the boundaries of required government action-such as the provision of education or of social services-denial of the benefit because of the exercise of a right would be construed simply as a failure to act.

In contemporary America, however, the boundaries are much harder to discern. Government has neither a clear obligation to protect property rights defined by natural law nor a mandate to avoid the fields of private action. Indeed, the reach of legitimate government action has extended far into areas previously reserved to the family, market and church, and this extension confounds easy definition of positive and negative rights. In a positive state, all rights are to some extent positive, for the government is often in a position to deal mortal blows to the exercise of rights by simply ceasing to intervene. If we are to distinguish sensibly among allocations that result in impacts on the exercise of constitutional rights, the mere invocation of a line between positive and negative rights will not do the job. ${ }^{105}$

\section{Doctrines of Active Review}

Both classical and modern doctrines supporting judicial deference to allocational sanctions prove, on examination, to be flawed. The question remains whether the lenses through which courts actively review allocational decisions are any more helpful.

The implicit challenge of the greater and lesser argument is to identify the manner in which the selective provision of benefits differs from absolute denial. The doctrines most consistently used for active review of allocational decisions respond by focusing on two of the differences discussed in the context of judicial deference. One argument starts from the proposition that the "consequence is not the measure of the condition," and concludes that an unconstitutional purpose behind

104198 U.S. 45 (1905).

220-320.

105 For my efforts to build a better mousetrap, see infra text accompanying notes 
an allocational decision invalidates it. The other argument looks to consequences, adopting the maxim that the government may not bring about indirectly any limitation on freedom that it could not accomplish directly. Both arguments can claim a longer line of antecedents than is generally adduced, and both continue to influence decisions. Neither, however, provides an adequate framework for active review of allocational sanctions.

\section{Unconstitutional Purpose}

In many areas the Constitution restricts the powers of government, not with substantive, but with procedural or structural limitations. Procedural due process, separation of powers, doctrines of federalism, and doctrines of delegation constrain not the consequences of the outcome, but the legitimacy of the paths by which the outcome is reached. Similarly, one interpretation of the currently reigning equal protection doctrine focuses on the intent behind government action as the criterion of the constitutionality of that action. ${ }^{108}$

For such limitations, Justice Holmes's challenge to scrutinize consequences is no challenge at all. Analysis begins and ends with the observation that, however uncoercive the outcome, the decision to seek it was adopted by illegitimate means.

A long line of cases involving government allocational decisions affecting constitutional rights have given decisive weight to whether the government sought to bring about that effect. The easiest solution to the dilemma of distinguishing a legitimate absolute denial from an unconstitutional condition is to appeal to invidious purposes in the decision to impose the conditions that are absent in the denial.

\section{a. Purpose Analysis and Constitutional Rights: The History}

In the Civil War loyalty oath case of Cummings $v$. Missouri, ${ }^{107}$ a priest was excluded from the practice of his ministry. His counsel, David Dudly Field, argued that even if the government had the power to regulate the ministry, the oath was illegal because it was intended to be a punishment for past disloyalty. The Court's opinion striking down the oath requirement seemed to accept this argument:

The purpose of the lawmaker in the case supposed would be openly avowed; in the case existing it is only disguised. The legal result must be the same, for what cannot be done di- 
rectly cannot be done indirectly. The Constitution deals with substance, not shadows. Its inhibition was levelled at the thing, not the name. It intended that the rights of the citizen should be secure against deprivation for past conduct by legislative enactment, under any form, however disguised. ${ }^{108}$

The case has been so interpreted by a solid line of subsequent cases. ${ }^{100}$

An analogous argument was advanced in the struggle over state power to impose conditions on the licensing of intrastate business by foreign corporations. Dissenting from a decision that approved the conditioning of a license on the corporation's surrender of its right to invoke federal diversity jurisdiction, Justice Bradley maintained,

The argument used, that the greater always includes the less, and, therefore, if the State may exclude the appellees without any cause, it may exclude them for a bad cause, is not sound. It is just as unsound as it would be for me to say, that, because I may without cause refuse to receive a man as my tenant, therefore I may make it a condition of his tenancy that he shall take the life of my enemy .... ${ }^{110}$

This argument prevailed in Barron $v$. Burnside, ${ }^{111}$ only to be supplanted again by the greater and lesser argument. ${ }^{112}$ Some commentators, alarmed by the possibility that the greater and the lesser argument might be used to justify increased state and federal regulation of corporations, urged a return to motive analysis. ${ }^{113}$ The years surrounding World War I saw a revival of reference to unconstitutional motives in the invalidation of regulatory legislation and taxation. ${ }^{14}$

108 Id. at 325.

109 Cummings is frequently cited for the proposition that the determination of whether a legislative act is a punishment turns not on how it is labelled, but on its substance and objectives. See, e.g., Kennedy v. Mendoza-Martinez, 372 U.S. 144, 16869 (1963) (intent determines whether statute denying citizenship to those who leave the country to evade military service is a punishment); Trop v. Dulles, 356 U.S. 86, $96 \&$ n.19 (1958) ("In deciding whether or not a law is penal, this Court has generally based its determination upon the purpose of the statute.") (footnote omitted).

Despite Professor Tribe's announcement of the demise of the punitive motive test after United States v. Brown, 381 U.S. 437 (1965), see L. TRIBE, AMERICAN ConsTITUTIONAL LAW $\S \S 10-4$ to 10-6 (1978), the news does not appear to have reached the Supreme Court. See Nixon v. Administrator of Gen. Servs., 433 U.S. 425, 475-84 (1977).

11 Doyle v. Continental Ins. Co., 94 U.S. 535, 543-44 (1876).

111121 U.S. 186, 197 (1887).

112 Security Mut. Life Ins. Co. v. Prewitt, 202 U.S. 246 (1906).

113 See, e.g., Beck, supra note 14; cf. Oppenheim, supra note 14, at 183 ("When the state seeks to exercise its recognized powers, it must not use them as a camouflage in attaining a constitutionally tabooed end.").

114 See, e.g., Bailey v. Drexel Furniture Co. (Child Labor Tax Case), 259 U.S. 
By the 1920's, even Justice Holmes, a perennial proponent of the greater and lesser argument, regularly found an "unlawful end" to be an invalidating characteristic. ${ }^{118} \mathrm{~A}$ comparison of his approach in Davis v. Massachusetts ${ }^{116}$ with his approach in the Western Union Telegraph Co. v. Foster ${ }^{117}$ is instructive. In Davis, Justice Holmes upheld the city's plenary power to bar speeches on the Boston Commons, while in Western Union, he invalidated a state's effort to exclude a price-cutting broker from a private tickertape service. Speaking for the Court in Western Union, Holmes struck down the regulation as an interference with interstate commerce:

It is suggested that the State gets the power from its power over the streets which it is necessary for the telegraph to cross. But if we assume that the plaintiffs . . . could be excluded from the streets, the consequence would not follow. Acts generally lawful may become unlawful when done to accomplish an unlawful end, and a constitutional power cannot be used by way of condition to attain an unconstitutional result. ${ }^{118}$

The constitutional revolution of the later 1930's curtailed inquiry into the purposes behind legislative actions. ${ }^{110}$ This is perhaps better understood, however, as a substantive change in the law, expanding the scope of legitimate federal power; the use of purpose analysis in decisions affecting other constitutionally protected areas continued to be crucial in the loyalty programs of the era following World War II. ${ }^{\mathbf{1 2 0}}$

20,38 (1922) (holding unconstitutional tax on products of child labor because it was intended to regulate commerce); Lipke v. Lederer, 259 U.S. 557, 561-62 (1922) (tax intended as punishment for violation of prohibition).

118 Justice Holmes relied on the greater and the lesser argument in both Motion Picture Patents Co. v. Universal Film Mfg. Co., 243 U.S. 502, 519-21 (1917) (Holmes, J., dissenting) (arguing that the tying of patented and nonpatented products would not violate antitrust laws) and Pullman Co. v. Kansas, 216 U.S. 56, 75-76 (1910) (Holmes, J., dissenting) (state's power to exclude foreign corporations entitles it to raise taxes on in-state business at any time). Nevertheless, he used motive analysis in several subsequent cases. See, e.g., Fidelity \& Deposit Co. v. Tafoya, 270 U.S. 426, 434-35 (1926) ("[T]he most absolute seeming rights are qualified, and in some circumstances become wrong. One of the most frequently recurring instances is when the socalled right is used as part of a scheme to accomplish a forbidden result.").

116167 U.S. 43 (1897).

117247 U.S. 105 (1918).

118 Id. at 114 (citations omitted).

119 See, e.g., United States v. Darby, 312 U.S. 100, 115 (1941); Sonzinsky v. United States, 300 U.S. 506, 513-14 (1937).

120 Thus, in upholding the exclusion of a pacifist from the Illinois bar, the Court stated, "Of course, under our Constitutional system, men could not be excluded . . . simply because they belong to any of our religious groups .... [But we] cannot say that any such purpose to discriminate motivated the action of the Illinois Supreme 
During the middle and late 1960 's, purpose analysis was generally eschewed. In United States $v . O^{\prime}$ Brien $^{121}$ and Palmer $v$. Thompson, ${ }^{122}$ the Court explicitly disavowed inquiry into governmental purpose as a legitimate form of constitutional review. ${ }^{\mathbf{1 2 3}}$

Court." In re Summers, 325 U.S. 561, 571 (1945).

Again, the Court sustained a statute excluding Communists from the leadership of labor unions because, although there was a "discouragement" of certain political perspectives, the statute was not "frankly aimed at suppression of dangerous ideas" and could not "be made the instrument of arbitrary suppression of free expression of views." "American Communications Ass'n v. Douds, 339 U.S. 382, $402-03$ (1950) (quoting Hague v. Committee for Indus. Org., 307 U.S. 496, 516 (1939)) (footnote omitted). Cf. Flemming v. Nestor, 363 U.S. 603, 611 (1960) ("This is not to say, however, that Congress may exercise its power to modify the statutory scheme [of social security] free of all constitutional restraint."); United Public Workers v. Mitchell, 330 U.S. 75, 100 (1947) ("Congress may not enact a regulation providing that no Republican, Jew or Negro shall be appointed to federal office, or that no federal employee shall attend Mass."). Compare Hague, 307 U.S. at 515-16 (holding unconstitutional ordinance forbidding distribution of handbills and holding of public meetings in streets because of purpose to suppress free expression) with Davis v. Massachusetts, 167 U.S. 43 (1897) (upholding similar because of purpose to promote convenience in public facilities). A more "frankly aimed" denial of tax benefits to those who decline to take a non-communist oath was struck down because of that frankness, see Speiser v. Randall, 357 U.S. 513, 519 (1958), while a denial of deductions for lobbying expenditures was held permissible, despite its discouragement of political speech, on the ground that it was not "aimed at the suppression of dangerous ideas," Cammarano v. United States, 358 U.S. 498, 513 (1959), quoted with approval in Regan v. Taxation with Representation, 103 S. Ct. 1997, 2001 (1983).

In the following Term, Justice Frankfurter invalidated the Tuskeegee gerrymander, invoking Justice Holmes's admonition that "“[a]cts generally lawful may become unlawful when done to accomplish an unlawful end." "Gomillion v. Lightfoot, 364 U.S. 339, 347 (1960) (quoting Western Union Tel. Co. v. Foster, 247 U.S. 105, 114 (1918)) (citation omitted). Conversely, a literacy test that had the effect of excluding blacks was held to be lawful because of its licit intent. See Lassiter v. Northampton County Bd. of Elections, 360 U.S. 45, 54 (1959).

121391 U.S. 367 (1968).

122403 U.S. 217 (1971).

$12 s$ See O'Brien, 391 U.S. at 383-84; Palmer, 403 U.S. at 224-26; see also United States v. Brown, 381 U.S. 437, 456-60 (1965); A. BICREL, THE LEAST DaNGerous BRANCH 208 (1962) ("The established view is that inquiries into motive are not open in the Supreme Court."); $c f$. Tenney v. Brandhove, 341 U.S. 367, 377 (1951) (improper motives cannot defeat legislative immunity from civil liability for conduct in legislative proceedings).

Not all cases so explicitly abandoned purpose analysis. Shapiro v. Thompson, 394 U.S. 618 (1969), danced nimbly around the question in finding that the exclusion of newly arrived out-of-state indigents from welfare benefits infringed the constitutionally protected right to travel. The Court spoke both in terms of purpose and effect. Compare id. at 628 ("There is weighty evidence that exclusion . . . of the poor who need or may need relief was the specific objective of these provisions.") and id. at 651-52 (Warren, C.J., dissenting) ("We do not attribute an impermissible purpose to Congress if the result would be to strike down an otherwise valid statute.") with id. at 634 (noting classification "serves to penalize the exercise of [right to travel]") and id. at 644 (Stewart, J., concurring) (State interest must be compelling " to justify the deterrent effect . on the free exercise . . of their constitutionally protected right." ") (quoting NAACP v. Alabama, 357 U.S. 449, 463 (1958)). 
Yet, even as inquiry into the processes of governmental decisionmaking disappeared from one line of cases, it appeared in another. The ban against content discrimination in regulations of free speech ${ }^{124}$ blossomed into a generalized obligation of neutrality, which at least some Justices interpreted as regulation without hostility. ${ }^{125}$ The dramatic renaissance of invidious intent as a determining factor in equal protection analysis ${ }^{126}$ coincided with the reemergence of unconstitutional purpose as an express consideration in review of government allocational decisions. In recent years the constitutionality of social security allocation conditions that affected the right to travel ${ }^{127}$ or the right to

Subsequent cases during the early 1970's characterized the intent interpretation of Shapiro as a "fundamental misunderstanding of the law." Dunn v. Blumstein, 405 U.S. 330,339 (1972). See Memorial Hosp. v. Maricopa County, 415 U.S. 250, 254-56 (1974) (interpreting Shapiro as effects analysis). But cf. Minneapolis Star \& Tribune Co. v. Minnesota Comm'r of Revenue, 103 S. Ct. 1365, 1380 (1983) (Rehnquist, J., dissenting) (no issue is raised nor is judicial scrutiny required unless constitutional rights have been intentionally infringed); Memorial Hosp., 415 U.S. at 285 (Rehnquist, 'J., dissenting) ("[T]he Court should examine . . . whether the challenged requirement erects a real and purposeful barrier to movement . . . or whether the effects . . . are merely incidental and remote.").

124 This prohibition against regulations of speech that vary with the views expressed was first articulated in Police Dep't v. Mosley, 408 U.S. 92, 95 (1972) ("[A]bove all else, the First Amendment means that government has no power to restrict expression because of its message, its ideas, its subject matter, or its content.").

Earlier cases already recognized that personal bias on the part of public officials toward certain views could not justify censorship of those views. See, e.g., Fowler v. Rhode Island, 345 U.S. 67, 69 (1953) (state may not prefer one religious group to another); Niemotko v. Maryland, 340 U.S. 268, $272-73$ (1951) (impermissible preference for certain religions in access to public parks); see also Perry Educ. Ass'n v. Perry Local Educators' Ass'n, 103 S. Ct. 948, 961-64 (1983) (Brennan, J., dissenting) (recounting history of content discrimination cases).

For a discussion of the content neutrality doctrine, see Farber, Content Regulation and the First Amendment: A Revisionist View, 68 GEo L.J. 727 (1980); Karst, Equality as a Central Principle in the First Amendment, 43 U. CHI. L. REv. 20 (1976); Redish, The Content Distinction in First Amendment Analysis, 34 STAN. L. REv. 113 (1981); Stephan, The First Amendment and Content Discrimination, 68 VA. L. REv. 203 (1982); Stone, Content Regulation and the First Amendment, 25 WM. \& MARY L. REv. 189 (1983); Stone, Restrictions of Speech Because of Its Content: The Peculiar Case of Subject-Matter Restrictions, 46 U. CHI. L. Rev. 81 (1978); Note, Content Regulation and the Dimensions of Free Expression, 96 HARv. L. Rev. 1854 (1983).

128 See, e.g., Greer v. Spock, 424 U.S. 828, 838-39 (1976); Erznoznik v. Gity of Jacksonville, 422 U.S. 205, 209-10 (1975); Southeastern Promotions, Ltd. v. Conrad, 420 U.S. 546, 556 n.8 (1975); Lehman v. City of Shaker Heights, 418 U.S. 298, 31517 (1974) (Brennan, J., dissenting); Healy v. James, 408 U.S. 169, 187-88 (1972); $f$. Carey v. Brown, 447 U.S. 455, 462-63 \& n.6 (1980) (striking statute banning residential picketing as content discrimination).

${ }^{128}$ See, e.g., Village of Arlington Heights v. Metropolitan Hous. Dev. Corp., 429 U.S. 252, 264-66 (1977); Washington v. Davis, 426 U.S. 229, 238-48 (1976).

127 Galifano v. Aznavorian, 439 U.S. 170, 177 (1978) (although admitting incidental impact on constitutional right to travel, upholding termination of social security payments for recipients who leave the country). 
marry ${ }^{128}$ and government employment conditions that affected freedom of speech ${ }^{128}$ have all turned on whether the action in question sprang from illegitimate state objectives. ${ }^{130}$

This analysis was triumphant in Board of Education, Island Trees Union Free School District No. 26 v. Pico. ${ }^{131}$ All members of the Court, but one, agreed that the propriety of the removal of books from a school library "depends upon the motivation behind petitioners' actions. If petitioners intended by their removal decision to deny respondents access to ideas with which petitioner disagreed, and if this intent was the decisive factor in petitioners' decision, then petitioners have exercised their discretion in violation of the Constitution."132 And in last Term's affirmances of the right of a school board to deny a union access to teachers' mailboxes ${ }^{133}$. and of the right of the government to provide tax relief for veterans' lobbying, ${ }^{134}$ a touchstone of the Court's opinions was the lack of invidious purpose.

128 See Califano v. Jobst, 434 U.S. 47, 54 n.11 (1977) (loss of benefits as a result of marriage acceptable because the regulations were not an attempt to interfere with freedom or a "governmental seek[ing] to foist orthodoxy on the unwilling").

129 See Elrod v. Burns, 427 U.S. 347 (1976) (plurality opinion by Brennan, J.) (patronage dismissal of government employee offends first and fourteenth amendments). The Court stated, "Regardless of the nature of the inducement, ... [i]f there is any fixed star in our constitutional constellation, it is that 'no official, high or petty, can prescribe what shall be orthodox." "Id. at 356 (quoting Board of Educ. v. Barnette, 319 U.S. 624, 642 (1943)). Stressing the centrality of purpose, Justice Brennan continued, "[G]overnment, however, may not seek to achieve an unlawful end either directly or indirectly." Id. at 359 n.13. "The denial of a public benefit may not be used by the government for the purpose of creating an incentive enabling it to achieve what it may not command directly." Id. at 361.

${ }^{130}$ See also United States Postal Serv. v. Council of Greenburgh Civic Ass'ns, 453 U.S. 114, 132 (1981) (access to mailboxes may be restricted in absence of intent to inhibit the expression of a particular view).

131457 U.S. 853 (1982).

13s Id. at 871 (plurality opinion by Brennan, J.). "To permit such intentions to control official actions would be to encourage the precise sort of officially prescribed orthodoxy unequivocally condemned in Barnette." Id. (referring to Board of Educ. v. Barnette, 319 U.S. 624 (1943)). See also Pico, 102 S. Ct. at 2814 (Blackmun, J., concurring) ("[S]chool officials may not remove books for the purpose of restricting access to the political ideas or social perspectives discussed in them, when that action is motivated simply by the officials' disapproval of the ideas involved."); id. at 883 (White, J., concurring in judgment) ("The unresolved factual issue . . . is the reason or reasons underlying the school board's removal of the books."). Justice Rehnquist dissented, joined by Chief Justice Burger and Justice Powell, but conceded that narrow partisan or political motives would be impermissible. See id. at 907-08; $c f$. Minneapolis Star \& Tribune Co. v. Minnesota Comm'r of Revenue, 103 S. Ct. 1365, 1381-82 (1983) (Rehnquist, J., dissenting) ("The tax is not a calculated device with illicit purpose; absent improper legislative motive, it cannot be construed as violating [the] first amendment."). (1983).

${ }^{193}$ See Perry Educ. Ass'n v. Perry Local Educators' Ass'n, 103 S. Ct. 948, 956-57

134 Regan v. Taxation with Representation, 103 S. Ct. 1997, 2002 (1983). 


\section{b. The Attraction of Purpose}

To a court reviewing allocational decisions, the appeal of purpose analysis is manifest. First, it responds to the greater and lesser argument with a plea of confession and avoidance. The government may admittedly have the power to deny benefits, but, like any governmental action, the basis for denial must always be legitimate. The argument seems particularly strong when first amendment rights are threatened. Whatever else they may embody, the guarantees of free speech and press are clearly directed against intentional censorship. When the actions and priorities of government itself are to be determined by the outcome of competing viewpoints in the marketplace of ideas, attempts by public officials to intervene in the workings of that market involve a logical contradiction and a grave political danger.

A second appealing aspect of purpose analysis lies in the appearance that emphasis on government purposes minimizes intrusion into the political arena by the courts. Such analysis purports not to constrain the goals or methods chosen by government except insofar as it excludes constitutionally suspect purposes. Any decision is prima facie permissible, so long as illegitimate purposes do not determine it. The courts do not require of the government any affirmative acts-they merely forbid one among many means of decisionmaking. Nor does the analysis require that courts establish a scale of values against which to judge the appropriateness of governmental actions or the consequences of those actions. The courts, therefore, are not vying with the legislature to establish priorities for governmental allocation decisions, but simply are identifying one impermissible set of criteria. They need not weigh interests, but only assay purposes.

\section{c. The Problems of Purpose}

In 1877, Justice Hunt opined that "[a]n unconstitutional reason or intention is an impracticable suggestion, which cannot be applied to the affairs of life." for purpose analysis runs aground on difficulties of definition and implementation. In simple cases-as where an individual official denies a benefit out of avowed hostility to the recipient's politics-the test functions adequately. But in a number of circumstances, it fails to address the crux of the problem. ${ }^{138}$

13s Doyle v. Continental Ins. Co., 94 U.S. 535, 541 (1877) (permitting state to revoke business license in retaliation for removal to federal court).

${ }^{18 B}$ This discussion in the text focuses on the motivational analysis that is prevalent in both modern and earlier doctrine. A parallel solution to the greater-lesser prob- 
Definition-The first difficulty lies in identifying those purposes that are proscribed. Granting, in first amendment contexts, that censorship is the paradigm of a constitutionally impermissible action, what charactizes censorship? Is it the purpose of reducing the amount of information available to citizens or the purpose of disfavoring unorthodox views? Must the proscribed purpose involve hostility to a given viewpoint, the desire to suppress a certain subject of discussion (whatever the viewpoint), or a distinction in the topic's treatment that can be taken to manifest a preference for a given type of discussion? Each of these candidates for the proscribed intent finds support in recent cases. ${ }^{137}$

Second, as in the equal protection area, ${ }^{\mathbf{1 3 8}}$ there is continuing un-

lem lies in a "first amendment due process" analysis that concedes the power to deny benefit for any reason, but, in areas with substantial impact on first amendment rights, requires special procedural protections. See Monaghan, First Amendment "Due Process," 83 HARv L. REv. 518 (1970). Although this route was in vogue in the late 1950 's and the 1960's, its appeal seems largely to have subsided with the demise of the irrebutable presumption doctrine. But cf. Kolender v. Lawson, 103 S. Ct. 1855 (1983) (striking for lack of adequate safeguards a statute permitting police to demand reliable identification from those with suspicious appearance).

137 Government may not attempt to reduce the amount of information available to citizens. See Virginia State Bd. of Pharmacy v. Virginia Consumer Council, 425 U.S. 748, 773 (1976); Consolidated Edison Co. v. Public Serv. Comm'n, 447 U.S. 530, 537 (1980). Government may not disfavor unorthodox views, see Branti v. Finkel, 445 U.S. 507, 514 (1980); Elrod v. Burns, 427 U.S. 347, 356 (1976), nor may it proscribe speech because of hostility to a given viewpoint, see Board of Educ. v. Pico, 457 U.S. 853, 870-72 (1982); Southeastern Promotions, Ltd. v. Conrad, 420 U.S. 546, 556 n.8 (1975). Government may not take as its objective the suppression of certain subjects of discussion, regardless of viewpoint. See Consolidated Edison, 447 U.S. at 538; Erznoznik v. City of Jacksonville, 422 U.S. 205, 212 (1975); Police Dep't v. Mosley, 408 U.S. 92, 96 (1972). Neither may government give preference to certain types of discussion or methods of treating a topic. See Widmar v. Vincent, 454 U.S. 263, 277 (1981). But $f f$. Metromedia, Inc. v. City of San Diego, 453 U.S. 490, 512 (1981).

138 The evolution of the Court's approach to equal protection, beginning with its rejection of intent analysis in Palmer v. Thompson, 403 U.S. 217, 224-26 (1971), through its adoption of the analysis in Washington v. Davis, 426 U.S. 229, 238-48 (1976), and the subsequent ebbs and flows, has spawned a legion of commentary attempting to eliminate the Court's apparently endemic confusion regarding what constitutes intent, who must possess it, and how it must be proven. See, e.g., Brest, The Supreme Court 1975 Term Foreword: In Defense of the Antidiscrimination Principle, 90 HaRv. L. REv. 1 (1976) [hereinafter cited as Brest, Antidiscrimination Principle]; Brest, Palmer v. Thompson: An Approach to the Problem of Unconstitutional Legislative Motive, 1971 Sup. CT. REv. 95 [hereinafter cited as Brest, Unconstitutional Legislative Motive]; Clark, Legislative Motive and Fundamental Rights in Constitutional Law, 15 San Diego L. Rev. 953 (1978); Eisenberg, Disproportionate Impact and Illicit Motive: Theories of Constitutional Adjudication, 52 N.Y.U. L. REv. 36 (1977); Ely, Legislative and Administrative Motivation in Constitutional Law, 79 YALE L.J. 1205 (1970); Schnapper, Perpetuation of Past Discrimination, 96 HARv. L. REv. 828 (1983); Schnapper, Two Categories of Discriminatory Intent, 17 HARv. C.R.-C.L. L. Rev. 31 (1982); Simon, Racially Prejudiced Governmental Actions: A Motivation Theory of the Constitutional Ban Against Racial Discrimination, 15 SAN Diego L. Rev. 1041 (1978); Comment, Proof of Racially Discriminatory Purpose Under the Equal 
certainty about the individual or institution that must harbor the proscribed purpose and the way in which that purpose is to be discovered. The paradigm case would be a single official who forbids a speech in the park because she believes that it is obnoxious to the prevailing orthodoxy. But such a case is rarely encountered.

Individual officials are unlikely to disclose impermissible motives, leaving the courts to engage in historical psychoanalysis to uncover the illegitimate motivation. More important, most allocation decisions are made not be a single individual, but by a collective legislative body or by a bureaucratic hierarchy through a series of determinations.

What can it mean to say that the legislature or the Department of Parks acted with hostility to a given viewpoint? Must the hostility have tainted the thinking of a majority of the legislature or only a majority of the proponents of the legislation? If the legislation passed by a single vote, is it sufficient that a single member harbored hostility to the views at issue? Must the plaintiff show that, absent hostility, the legislation would not have passed, or must a defendant prove that hostility played no part in the decisionmaking process? What if all members were neutral but responded to hostility expressed by their constituents?

The most tempting answer, absent an explicit official avowal of the forbidden purpose, is to anthropomorphize the governmental entity in question, treating it as an individual and applying to it the commonsense tests by which courts interpret the purposes of persons. ${ }^{139}$ Thus, if an individual in similar circumstances would not act in a given way but for an illicit purpose, then we may ascribe that purpose to a government that acts in that way. This approach seems to be the basis of Justice White's plurality opinion in Metromedia, Inc. $v$. City of San Diego. ${ }^{140}$ In determining whether the government had demonstrated a sufficient interest in banning billboards to warrant banning those carrying noncommercial speech, he wrote, "Governmental interests are only revealed and given concrete force by the steps taken to meet those interests."141 Because the city's actions in the noncommercial field did not match its preferences revealed. in the commercial field, the ordi-

Protection Clause, Washington v. Davis, Arlington Heights, Mt. Healthy, and Williamsburg, 12 Harv. C.R.-C.L. L. REv. 725 (1977); Note, Making the Violation Fit the Remedy: The Intent Standard and Equal Protection Law, 92 YALE L.J. 328 (1982); Note, Reading the Mind of the School Board: Segregative Intent and the De Facto/De Jure Distinction, 86 YALE L.J. 317 (1976).

${ }_{139} C f$. J. RAwLS, A TheORY OF Justice 468-69 (1971) (describing cognitive development of ability to ascribe motives to others).

${ }_{110} 453$ U.S. 490 (1981) (plurality opinion by White, J.); cf. Carey v. Brown, 447 U.S. 455, 465 \& n.9 (1980) (overinclusiveness and underinclusiveness impeaches state's rationale for regulation).

141453 U.S. at 521. 
nance was invalidated, with the intimation that an illegitimate purpose was present. ${ }^{142}$ Justice White's argument roughly followed this structure: (1) by excepting certain commercial billboards from regulation, the city demonstrated that commercial speech was more important than esthetics; (2) by constitutional mandate, noncommercial speech is more important than commercial speech; (3) therefore, noncommercial speech is more important than esthetics. Failure to act in accord with this primacy was a constitutional violation.

There are at least two difficulties with this argument; both arise out of the anthropomorphic inferences behind it. First, to act in a way that suggests greater weight is given to certain modes of discourse is not tantamount to intentional censorship. Simple incompetence and random error may generate the observed actions on which Justice White determined legislative preferences, without any illegitimate priorities or biases. Even individuals often carry out a series of actions without comparing the values in each line of endeavor. In organizations this tendency is exacerbated because human errors combine with failures of communication. What might reveal purposes or preferences in an individual may simply reveal random error in an organization.

Second, even a well-constructed and comprehensively rational process may produce inconsistent outcomes when more than one individual is involved. Justice White's logic rests on an assumption about transitive ${ }^{143}$ preferences that-however intuitively appealing when applied to individuals-is often misleading when applied to organizations. Majority voting, as has been long since demonstrated, may often yield intransitive $^{144}$ results. ${ }^{145}$ If we posit three voters-Esthete, who prefers beauty to politics and politics to commercial speech; Merchant, who prefers commercial speech to beauty, and beauty to politics; and White, who prefers politics to commercial speech and commercial speech to beauty-two out of three may have the "legitimate" preference of valuing politics more than commercial speech, while two out of three also prefer beauty to politics. Treating political preferences as the result of a single anthropomorphic process does not in fact defer to the political process. Rather than taking the values that resulted from a majority

${ }^{142} I d$. at $515-17,520-21$.

148 As used in this context, "transitive" describes the internal consistency of the ranking of preferences. A ranking of preferences $x, y$, and $z$ is transitive if $x$ is at least as preferred as $y, y$ is at least as preferred as $z$, and $x$ is then at least as preferred as $z$. See A. Sen, Collective Choice and Social Welfare, 2 (1970). Were $x$ less preferred than $z$, the ranking would be intransitive.

144 See supra note 143.

146 See K. Arrow, Social Ghoice and Individual Values (1951); A. Sen, supra note 143 , at $33-46,161-86$. 
voting procedure, Justice White imposed his own.

The problem is generalizable: whenever a case involves multiple decisionmakers, or a single decisionmaker who declines to admit an illicit purpose, the court must infer purposes from government actions. In order to infer that a decision was tainted by an impermissible purpose, the court must determine what the government would have done in the absence of that purpose. But in order to make that determination, the courts must have a model of the way that a proper government would act. Implicit in the constructing of such a model is precisely the weighing of values that purpose analysis promised to avoid. The prediction of what a government would do becomes the norm against which the government is judged. ${ }^{146} \mathrm{~A}$ focus on purpose, therefore, encourages the court to smuggle its own preferred values into the analysis without the discipline of expressly articulating the content or underpin- . nings of those values.

Implementation-The ambiguities of definition in purpose analysis are mirrored by the difficulties in its implementation. If the purposes at issue are the thoughts running through the minds of individual decisionmakers as they adopt policies that impinge on constitutional rights, then the door is open for the cross-examination of individual legislators. Factual determinations by the trial court will be virtually unreviewable. ${ }^{147}$ If, on the other hand, the court adopts a metaphorical conception of purpose as an invalidating residual divergence from the norm of good government, they embark on exactly the flight of normative prescription, almost unconstrained by concrete factual reference, that the purpose analysis sought to avoid.

In this regard, the inquiry into intent suffers from an analogue of the ahistoricity of the greater and lesser argument. Justice Harlan could, with a straight face, maintain that a McGarthy era prohibition against payment of vested Social Security benefits to deported communists was animated by the purpose of aiding the country's balance of

146 In the equal protection area there may be some greater justification for examining whether the government has acted in a way that appears to involve invidious intent. To the extent that the guarantee of equal protection proscribes actions that stigmatize a "suspect class," the possibility of denigrating a minority may itself be grounds for constitutional review.

${ }^{147}$ See Rogers v. Lodge, 458 U.S. 613, 618 (1982) ("Discriminatory intent need not be proven by direct evidence."; upholding trial court's inference of intent on basis of facts virtually identical to those held insufficient to establish intent in City of Mobile v. Bolden, 446 U.S. 55 (1980)); Pullman-Standard v. Swint, 456 U.S. 273, 285-90 (1982) (applying "clearly erroneous" standard of review to findings of discriminatory intent under Title VII). But cf. Dayton Bd. of Educ. v. Brinkman, 443 U.S. 526, 534-37 (1979) (upholding appeal's court reversal of trial court's finding of discriminatory purpose). See generally Note, Making the Violation Fit the Remedy: The Intent Standard and Equal Protection, 92 YALE L.J. 328, 348-49 (1982). 
trade, ${ }^{148}$ while Justice Brennan, with equal seriousness, could advance the thesis that legislation that explicitly denied the recently impeached President Nixon access to his papers, just happened to be the fortuitous result of the timing of congressional interest. ${ }^{149}$ Courts that upheld the termination of Medicaid funds for abortions found the purpose of the statutes was to encourage childbirth rather than to prevent abortions. And this past Term, Justice White held that union contracts denying rival unions access to employee mailboxes was untainted by any intention "to discourage one viewpoint and advance another."150

In part, this insensitivity to reality results from the vulnerability of the boundaries of purpose to the "principle of double effect."151 Where a statute accomplishes two effects, one permitted and one that would be proscribed if it were intended, the government may freely argue that it intended only the permitted effect. The unconstitutional result is said to be merely an unfortunate by-product. If purpose is the sole test of constitutional validity and the plaintiff bears the burden of proof, the astute will usually survive. Almost any statute has a myriad of effects, and the government will usually be able to claim that it intended only the constitutional ones. ${ }^{152}$

Problems of over-inclusiveness and under-inclusiveness-Purpose analysis is not only ill-defined and difficult to apply, it is over-inclusive and under-inclusive as well. It simply does not answer objections to the imposition of unconstitutional conditions.

Picture, for example, the National Endowment for the Arts (NEA) choosing among applicants for grants in oil painting. No applicant is entitled to the grant. However, if the NEA excludes all Republican applicants, most would agree they have been subject to an unconstitutional allocational sanction. It is easy enough to attribute this result to an illegitimate purpose on the part of NEA to prefer one exercise of first amendment rights to another. (1983).

148 See Flemming v. Nestor, 363 U.S. 603, 612 (1960).

148 See Nixon v. Administrator of Gen. Servs., 433 U.S. 425 (1977).

150 Perry Educ. Ass'n v. Perry Local Educators' Ass'n, 103 S. Ct. 948, 957

${ }_{181}$ See generally Boyle, Toward Understanding the Principle of Double Effect, 90 ETHICs 527 July (1980) (discussing moral and philosophical problems presented by actions that produce both good and evil consequences).

162 See, e.g., Perry Educ. Ass'n v. Perry Local Educators' Ass'n, 103 S. Ct. 948, 954-59 (1983) (effect was to exclude rival teachers union, but purpose was to keep labor peace). While it is possible to conceive of statutes that would serve no rational purpose other than penalizing constitutional rights, the nature of allocational sanctions, in particular, suggests that this will rarely be the case in the areas at issue here. At the very least, denial of benefits would almost always serve the purpose of conserving government funds. And the same sanction can usually be characterized as the grant of benefits to an alternate activity rather than as a denial to the victim. 
On the other hand, if the grants are awarded only to pointilists and denied to cubists, the NEA also has a purpose of preferring one exercise of first amendment rights to another. Nonetheless, the cubists' complaint is substantially more tenuous.

Recent cases further illustrate the over-inclusiveness of purpose analysis. An intent to discourage interstate migration is equally present whether a state gives better service than its neighbors-and thus discouraging emigration-or alternatively imposes a tax upon emigrants. Yet the former apparently would be constitutional and the latter impermissible. ${ }^{183}$ The threat to fire a presidential spokesman who criticizes a foreign affairs blunder betokens a hostility to that criticism no less than imposition of a fine. Yet few would question the propriety of the former or assert the validity of the latter. ${ }^{164}$ The refusal to acquire and the agreement to remove an offending book from a school library are equally motivated by objection to the ideas expressed. Nonetheless, the Court has apparently accepted a distinction between the two acts. ${ }^{185}$ Something other than purpose must be the deciding factor.

On the other hand, the under-inclusiveness of purpose analysis is equally apparent. In Sherbert $v$. Verner, ${ }^{158}$ the Court declared that a state that conditions unemployment benefits on an activity that violates the applicant's religious beliefs violates the free exercise clause. Twenty years later in Thomas $v$. Review Board ${ }^{\mathbf{1 5 7}}$ the Court reaffirmed its holding. ${ }^{158}$ In neither case did the Court determine that the state had any intent to deter religious practices. ${ }^{158}$

188 Cf. Zobel v. Williams, 457 U.S. 55 (1982) (holding unconstitutional state allocation of royalties from Alaskan pipeline to residents of Alaska based on length of residence).

134 Cf. Lefkowitz. v. Cunningham, 431 U.S. 801 (1977) (Stevens, J., dissenting):

The First Amendment protects the individual's right to speak and believe in accordance with the dictates of his own conscience. But if he believes in peace at any price and speaks out against a strong military, the President may decide not to nominate him for Secretary of Defense. . . [or] may remove him as a result of his exercise of First Amendment rights.

Id. at 810 .

${ }_{188}$ See Board of Educ. v. Pico, 457 U.S. 853 (1982) (4-1-4). Justice Brennan's plurality suggestion on the issue may, however, be dictum.

158374 U.S. 398, 403-06 (1963).

187450 U.S. 707 (1981).

168 Id. at 720.

180 For other cases where the impact on constitutional rights was crucial without reference to censorious government intent, see In re Primus, 436 U.S. 412, 432-33 (1978); Wooley v. Maynard, 430 U.S. 705, 715 (1977) ("As a condition of driving the automobile-a virtual necessity for most Americans-the Maynards must display "Live Free or Die." "); NAACP v. Button, 371 U.S. 415, 438-39 (1963); Martin v. Struthers, 319 U.S. 141 (1943). 
Similarly, in Branti v. Finkel, ${ }^{160}$ the intent of a county employer in declining to renew the plaintiffs' patronage positions for want of their sponsorship by the prevailing political party was not to coerce the plaintiffs into changing parties, but was simply to reward those who supported an electoral campaign. As the court held last Term, rewarding supporters is an element of electoral politics that may be constitutionally protected. ${ }^{\mathbf{1 6 1}}$ Nonetheless, firing an individual because she associates with the "wrong" party is unacceptable. ${ }^{\mathbf{1 0 2}}$

Most recently, in Minneapolis Star E Tribune Co. v. Minnesota Comm'r of Revenue, ${ }^{163}$ Justice O'Connor's opinion invalidated a sales tax that treated newspapers differently from other goods, despite the absence of invidious intent. ${ }^{164}$ To find a workable principle that acceptably orders both our intuitions and the case results, we must look beyond the search for illegitimate governmental purposes.

\section{Unconstitutional Impact}

The second major doctrine of active review accepts the notion that the "consequence is the measure of the condition," but views the consequence in question as the effect of government action on constitutionally protected areas of choice. If the consequence impinges upon a protected area in a way that would be unconstitutional had the same result flowed from a direct governmental command, this "impact analysis" would invalidate the condition. A $\$ 10,000$ reduction in benefits for exercising a constitutional right is said to be no more permissible than a $\$ 10,000$ fine. The evil in each case is a government-imposed penalty for the exercise of a constitutional right.

This analysis claims to be rooted in the very essence of constitutional guarantees. If the purpose of the guarantee is to reserve certain areas of conduct to the untrammeled choice of citizens, then permitting government to use its conceded powers to manipulate decisions in those areas ultimately undermines the autonomy that the Constitution seeks to protect. The entire society may become subject to indirect governmental control.

The argument was fully formed at least as early as the onset of the struggle over the use of state licensing power to regulate out-of-state corporations. Justice Day championed the position that permitting an

160445 U.S. 507, 516-17 (1980).

181 Brown v. Hartlage, 456 U.S. 45, 54-59 (1982).

162 Branti v. Finkel, 445 U.S. 507 (1980).

163103 S. Ct. 1365 (1983).

184 Id. at 1372. 
impact on a constitutionally protected area

amounts to a practical nullification in respect to such corporations of the supreme law of the land and places important constitutional rights at the mercy of the several States. . . .

[T]here is nothing to prevent the State from applying the same doctrine to any other constitutional right. . . . In pursuance of the principle announced in this case, ... the State may say to the foreign corporation,-Y You may do business within this State, provided you will yield all right to be protected against deprivation of property without due process of law; or provided you surrender your right to have compensation . . . [or] to the equal protection of laws; and so on through the category of rights secured by the Constitution and deemed essential to the protection of people and corporations living under our institutions. ${ }^{\mathbf{1 0 5}}$

On this theory, the defect in the unconstitutional condition is not the purpose of the government action but the impact of the action on constitutionally protected prerogatives. "[T]he disavowal by the State of any purpose to burden interstate commerce cannot conclude the question. . . . If the statute, reasonably interpreted, either directly or by its necessary operation, burdens interstate commerce, it must be adjudged to be invalid, whatever may have been the purpose for which it was enacted ....."186

${ }_{108}$ Security Mut. Life Ins. Co. v. Prewitt, 202 U.S. 246, 266-67 (1906) (Day, J., dissenting). In Western Union Tel. Co. v. Kansas, 216 U.S. 1 (1910), Justice Harlan wrote for the Court,

To hold otherwise is to allow form to control substance. It is easy to be seen that if every State should pass a statute similar to that enacted by Kansas not only the freedom of interstate commerce would be destroyed, the decisions of this court nullified and the business of the country thrown into confusion ....

Id. at 37. See also Baltic Mining Co. v. Massachusetts, 231 U.S. 68, 83 (1913); Pullman Co. v. Kansas, 216 U.S. 56, 63 (1910); cf. Philadelphia Fire Ass'n v. New York, 119 U.S. 110, 120 (1886) (Harlan, J., dissenting).

Justice Sutherland picked up the torch in rejecting an attempt to impose common carrier status on private contract carriers as a condition of using public roads. Although part of the opinion in Frost \& Frost Trucking Co. v. Railroad Comm'n, 271 U.S. 583 (1926), spoke of the unconstitutional purpose that was found to underlie the statute, see id. at 591-93, it also emphasized that "[i]] the state may compel the surrender of one constitutional right as a condition of its favor, it may, in like manner, compel a surrender of all. It is inconceivable that guarantees embedded in the Constitution of the United States may thus be manipulated out of existence." 271 U.S. at 594, quoted in Harris v. McRae, 448 U.S. 297, 337 (1980) (Brennan, J., dissenting).

166 Western Union Tel. Co. v. Kansas, 216 U.S. 1, 27 (1910). See Terral v. Burke Constr. Co., 257 U.S. 529, 532 (1922) (statute "necessarily calculated to curtail" access 
In Stephenson v. Binford, ${ }^{167}$ Justice Sutherland retreated from this position, adopting instead a more limited rationale looking to the purposes of the statute. ${ }^{168}$ This latter line of inquiry predominated through the demise of Lochner $v$. New York ${ }^{169}$ and federalism doctrines that underlay much earlier constitutional invalidation. With the re-emergence of the unconstitutional conditions problem in the form of loyalty oath enactments in the late 1940's and early 1950's, however, impact analysis was resurrected by opponents of the oaths. In addition to arguing that the true purpose of the oath requirements was the suppression of unorthodox ideas, dissents by Justices Black, Douglas, and Brennan all based claims of unconstitutionality on the impact of the loyalty programs on the exercise of first amendment liberties. ${ }^{170}$

Speiser v. Randall ${ }^{171}$ was a watershed, the first major case since the Civil War invalidating a loyalty program by repudiating the greater and lesser argument. Justice Brennan's opinion looked both ways on the issue of intent and effect. While distinguishing other loyalty programs that had been upheld as not having been "frankly aimed at the suppression of dangerous ideas,"172 Justice Brennan also emphasized that the denial of a tax exemption for engaging in certain speech "will have the effect of coercing the claimants to refrain from the proscribed

to federal court is invalid); Hammer v. Dagenhart, 247 U.S. 251, 276 (1918) (holding unconstitutional statute prohibiting interstate trade in products of child labor because its "necessary effect" was to regulate intrastate commerce); Insurance Co. v. Morse, 87 U.S. (20 Wall.) 445, 458 (1874) (statute excluding company that refused to waive right of access to federal court "is an obstruction to this right" and therefore "repugnant to the Constitution of the United States"); see also Frost \& Frost Trucking Co. v. Railroad Comm'n, 271 U.S. 583, 592 (1926) (asking "whether the state may bring about the same result by imposing the unconstitutional requirement as a condition precedent to the enjoyment of a privilege"). Antecedents of this position may be found in Civil War loyalty oath cases. See, e.g., Cummings v. Missouri, 71 U.S. (4 Wall.) 277, 327 (1866) (oath requirement will effectively "produce the same result . . . as though the crimes were defined").

167287 U.S. 251 (1932).

188 See id. at 267-68.

169198 U.S. 45 (1905).

170 See Beilan v. Board of Educ., 357 U.S. 399, 418 (1958) (Brennan, J., dissenting) ("[C]lose judicial scrutiny is essential when state action infringes on the right of a man to be accepted in his community, to express his ideas in an atmosphere of calm decency, and to be free of the dark stain of suspicion . . . on account of his political beliefs and associations."); Adler v. Board of Educ., 342 U.S. 485, 509 (1952) (Douglas, J., dissenting) ("Fearing condemnation, [the teacher] will tend to shrink from any association that stirs controversy. In that manner freedom of expression will be stifled."); American Communications Ass'n v. Douds, 339 U.S. 382, 446 (1950) (Black, J., dissenting) ("Freedom to think is inevitably abridged when beliefs are penalized by imposition of civil disabilities.").

171357 U.S. 513 (1958).

172 Id. at 519 (quoting American Communications Ass'n v. Douds, 339 U.S. 382, 402 (1950)). 
speech."173 This emphasis formed the groundwork for his later opinion in Sherbert $v$. Verner, ${ }^{174}$ which revitalized impact analysis. ${ }^{175}$

Although in Sherbert there was no evidence of animus directed against Seventh Dáy Adventists and no direct prohibition of their observances, Justice Brennan, writing for the Court took the position that

not only [does her] declared ineligibility for benefits derive[] solely from the practice of her religion, but the pressure upon her to forego that practice is unmistakable. The ruling forces her to choose between following the precepts of her religion and forfeiting benefits. ... [This constitutes] the same kind of burden upon the free exercise of religion as would a fine. ... ${ }^{178}$

Speiser was cited for the proposition that "conditions upon public benefits cannot be sustained, if they so operate, whatever their purpose, as to inhibit or deter the exercise of First Amendment freedoms."177 The state, it was said-in reliance on Speiser-had acted improperly by the "imposition of such a condition ... . [that] inevitably deterred or discouraged the exercise of First Amendment rights . . . and thereby threatened to 'produce a result which the State could not command directly.'

A concern for the impact of allocational sanctions on constitutional rights predominated throughout the next decade, and opinions frequently invoked the shades of the early corporate rights cases. ${ }^{178}$ Yet,

17 Id. at 519.

174374 U.S. 398 (1963).

176 Admittedly, inquiries into purpose and effect overlap. Under the anthropomorphic interpretation of purpose, the same factual elements are relevant in roughly the same way whether the plaintiff claims that there is an illicit effect and no interest of sufficient weight to justify the impact or claims that there is an illicit purpose because no legitimate purpose adequately explains the government's actions. The theoretical roots of the two complaints are distinct, however. If impingement of constitutional rights establishes a prima facie violation that might subsequently be justified, then the evil is the restriction of autonomy. If inadequately explained impact is used to infer purpose, then the underlying evil is the purpose of the governmental action.

176374 U.S. at 404.

177 Id. at 405 (refering to Speiser, 357 U.S. at 513) (emphasis added).

178 Id. (quoting Speiser, 357 U.S. at 526). Both citations were ambitious uses of precedent. Speiser seemed to hold that a proper purpose could legitimate "deterrence" of first amendment rights and the language regarding the "result which the State could not command directly" referred to the effect of an oath required to qualify for the tax benefit in shifting the burden of proof to the claimant. See Speiser, 357 U.S. at 526. Nonetheless, the revisionism was in tune with the emerging line of analysis, which recalled the pronouncements of the first Justice Harlan and of Justice Sutherland.

170 In Harman v. Forssenius, 380 U.S. 528 (1965), the Court invalidated a provision requiring advance registration of voters to avoid a poll tax. Although the statute could plausibly have been represented as an attempt to promote advance registration, 


\section{interwoven with a reaffirmation of the importance of the impact of de-}

this legitimate purpose did not save it from conflict with the twenty-fourth amendment. The unanimous opinion declared that "[a]ny material requirement imposed upon the federal voter solely because of his refusal to waive the constitutional immunity subverts the effectiveness of the Twenty-fourth Amendment and must fall under its ban." Id. at 542.

In the same year, the Court invalidated a provision that communist propaganda would be delivered only on the recipient's written notification to the post office of the desire to receive such materials. Though no penalty was attached to the notification, the Court found this to be an "unconstitutional abridgement of the addressee's First Amendment rights . . . [because this] requirement is almost certain to have a deterrent effect, especially as respects those who have sensitive positions." Lamont v. Postmaster General, 381 U.S. 301, 307 (1965). See also id. at 309 (Brennan, J., concurring) ("inhibition as well as prohibition against the exercise of precious First Amendment rights is a power denied to government").

Succeeding Terms saw the invalidation of a previously approved loyalty program for public school teachers because of the "danger of [a] chilling effect upon the exercise of vital First Amendment rights[,]" Keyishian v. Board of Regents, 385 U.S. 589, 604 (1967); cf. Pickering v. Board of Educ., 391 U.S. 563, 568 (1968) (public employment does not compel relinquishment of all first amendment rights); the invalidation of a requirement that policemen waive fifth amendment rights as a condition of employment because "[t]here are rights . . . whose exercise a State may not condition by the exaction of a price[,]" Garrity v. New Jersey, 385 U.S. 493, 500 (1967); and the invalidation of a kidnapping statute that imposed the death penalty only after trial by jury because "[t]he inevitable effect of any such provision is, of course, to discourage assertion of the Fifth . . . and Sixth Amendment right[s]," United States v. Jackson, 390 U.S. 570, 581 (1968); see also id. at 582 ("The question is not whether the chilling effect is 'incidental' rather than intentional . ....").

These cases did not rest on a determination that the government had no power to set registration requirements, to decline to deliver mail, to discharge teachers and policemen, or to set criminal penalties. Nor was there any finding that the purpose of the actions taken was to prevent the exercise of constitutional rights. They were, rather, holdings that the consequence of the challenged actions in each case was to penalize and impermissibly discourage the exercise of such rights.

A similar approach was applied to invalidate the denial of government employment for unpopular speech. See Perry v. Sindermann, 408 U.S. 593, 597 (1972) ("II]f the government could deny a benefit to a person because of his constitutionally protected speech or associations, his exercise of those freedoms would in effect be penalized and inhibited. This . . . '[it] could not command directly." ") (quoting Speiser, 357 U.S. at $526(1958)$ ). So too, the Court invalidated restrictions on access to campus facilities for unpopular associations. See Healy v. James, 408 U.S. 169, 181 (1972) ("There can be no doubt that denial of official recognition, without justification, to college organizations burdens or abridges that associational right."). The same reasoning was applied in the case of denials of public employment that were rooted in patronage practices. See Elrod v. Burns, 427 U.S. 347, 355 (1976) (plurality opinion by Brennan, J.) ("The cost of the practice of patronage is the restraint it places on freedoms of belief and association."); see also id. at 356 (The "individual's ability to act according to his beliefs ... is constrained."); id. at 358 n.11 ("This Court's decisions have prohibited conditions on public benefits, in the form of jobs or otherwise, which dampen the exercise generally of First Amendment rights, however slight the inducement to the individual to forsake those rights.").

Similarly, Shapiro v. Thompson, 394 U.S. 618 (1969), relied in part on the argument that durational residence requirements for welfare recipients served as an "effective penalty" on the exercise of a constitutionally protected right to travel. "[A]ny classification which serves to penalize the exercise of that right, unless shown to be necessary to promote a compelling governmental interest, is unconstitutional." Id. at 
nied benefits on constitutional rights is a perception that not all allocations that provide inducements in constitutionally protected areas constitute proscribed burdens. If the NEA refuses to fund cubists, cubism may wither, yet there is no constitutional mandate to fund cubists. The cessation of welfare payments by one state upon emigration to another state lacking similar funding constitutes a severe disincentive to interstate travel, yet it is clear that such a scheme is not unconstitutional. ${ }^{\mathbf{1 8 0}}$ A tax deduction for dependent children constitutes an incentive to forego one's right to remain sterile, and favored tax treatment upon marriage is an incentive to marry, yet both are uncontroversial. ${ }^{181}$ An offer of $\$ 100,000$ to a small town newspaper to run an anti-smoking campaign is an inducement to print what could not be required, but it seems an acceptable one. Some limiting principle is necessary. Unfortunately, no satisfactory one has been adopted.

At the high-water mark of impact analysis, Justice Marshall made an effort to build a stopping place into the doctrine by specially defin-

634.

In Dunn v. Blumstein, 405 U.S. 330 (1972), the Court struck down a one-year residency requirement for voting. Justice Marshall, writing for the Court, reiterated that "any classification which serves to penalize the exercise of that right" "triggers a compelling state interest requirement. Id. at 340 (citing Shapiro v. Thompson, 394 U.S. 618, 634 (1969)). Characterizing a focus on legislative purpose as a "fundamental misunderstanding of the law," $i d$. at 339, he identified the evil of the requirement as its effect in forcing "a person who wishes to travel and change residences to choose between travel and the basic right to vote." Id. at 342. See also Memorial Hosp. v. Maricopa County, 415 U.S. 250, 256 (1974) (striking one-year residency requirement for medical care for indigents as a penalty on interstate migration and as an indirect method of accomplishing an unconstitutional result); $c f$. Zablocki v. Redhail, 434 U.S. 374,387 \& n.12 (1978) (finding unconstitutional requirement for court order establishing ability to support children of prior marriage before new marriage license will be issued as direct and substantial interference with right to marry).

In 1981, Chief Justice Burger, writing for the Court in Thomas v. Review Bd., 450 U.S. 707 (1981), reaffirmed Sherbert v. Verner, 374 U.S. 398 (1963). In holding that a state may not deny unemployment benefits to a pacifist discharged for refusing to work on military equipment, Burger wrote,

Where the state conditions receipt of an important benefit upon conduct proscribed by a religious faith, or where it denies such a benefit because of conduct mandated by religious belief, thereby putting substantial pressure on an adherent to modify his behavior and to violate his beliefs, a burden upon religion exists.

Thomas, 450 U.S. at 717-18.

And in Zobel v. Williams, 457 U.S. 55 (1982), the Court repeated its commitment to the right of interstate mobility by striking down an Alaskan statute that discriminated against newer residents in the distribution of oil royalties. See id. at 58-65 \& 60 n.6; see also id. at 66-68 (Brennan, J., concurring) (stressing right to travel and migrate), id. at 71-81 (O'Connor, J., concurring in judgment) (expressly invoking privileges and immunities clause of fourteenth amendment).

180 See Califano v. Torres, 435 U.S. 1, 4-5 (1978).

181 See Califano v. Jobst, 434 U.S. 47 (1977). 
ing the "penalty" that would trigger constitutional review. Attempting to distinguish cases upholding a durational residency requirement on in-state college tuition from the residency requirement on free medical care at issue, Marshall suggested in Memorial Hospital v. Maricopa County ${ }^{182}$ that the forbidden penalty was an allocation that deprived the victim of a "fundamental political right" or the "basic necessit[ies] of life."18s A deprivation of "sufficient importance"184 would constitute a penalty, while the allocation of lesser goods might still be conditioned on residence. Leaving aside this peculiar use of language-that a ten dollar fine might not be a penalty-Justice Marshall's proposal has not been adopted. Just as the ranking of interests Justice Marshall suggested in equal protection analysis has not prevailed, ${ }^{185}$ the Court has declined to make its impact analysis turn on the importance of the deprivation. On one hand, in Sosna v. Iowa ${ }^{186}$ decided a year after Maricopa County, the Court held that one's ability to obtain a divorce could be conditioned on duration of residence, ${ }^{187}$ and in Maher $v . R o e^{\mathbf{1 8 8}}$ and Harris $v . M c R a e^{189}$ the majority held that withholding medical assistance-concededly necessary for indigents to exercise their rights to abortions-did not penalize their exercise of those abortion rights. ${ }^{190}$ On the other hand, in Zobel $v$. Williams, ${ }^{191}$ the Court struck down an oil revenue distribution scheme that pegged payments to the number of years residents had lived in the state as a violation of interstate travel rights, though it is difficult to characterize such a bonus as a "necessity of life." 192 The Court has similarly invalidated the conditioning of tax exemptions, ${ }^{193}$ access to the mails, ${ }^{194}$ unemployment compensation, ${ }^{195}$ and government employment, ${ }^{196}$ without any suggestion that these

182415 U.S. 250 (1974).

183 Id. at 259.

184 Sosna v. Iowa, 419 U.S. 393, 419 (1975) (Marshall, J., dissenting).

${ }^{188}$ But see Plyler v. Doe, 457 U.S. 202, 221-23 (1982) (considering the importance of education in determining the appropriate standard of review).

${ }_{188} 419$ U.S. 393 (1975).

187 Id. at $404-10$.

188432 U.S. 464 (1977).

189448 U.S. 297 (1980).

180 See Maher, 432 U.S. at 469-74; Harris, 448 U.S. at 316-17.

191457 U.S. 55 (1982).

102 Compare the Alaska Supreme Court's opinion, Williams v. Zobel, 619 P.2d 448, 455-57 (Alaska 1980), rev'd, 457 U.S. 55 (1982), in which Chief Justice Rabinowitz, who cast the deciding vote to uphold the statute, was misled by taking seriously the analysis used in Maricopa County.

193 See Speiser v. Randall, 357 U.S. 513 (1958).

194 See Lamont v. Postmaster General, 381 U.S. 301 (1965).

398 (1963) Thomas v. Review Bd., 450 U.S. 707 (1981); Sherbert v. Verner, 374 U.S.

${ }_{108}$ See Branti v. Finkel, 445 U.S. 507 (1980); Elrod v. Burns, 427 U.S. 347 
items were either fundamental rights or basic necessities.

If analysis of the importance of the right affected reaches the wrong answers, the other proposal occasionally advanced-that the permissibility of constitutionally questionable allocations turn on the directness or substantiality of the impact ${ }^{\mathbf{1 0 7}}$ - provides no answers at all, for it invites ad hoc constitutional balancing. We now turn to consideration of this balancing.

\section{Balancing and Reasonableness}

A number of judges and commentators have been unable to accept the total immunity of allocational sanctions to constitutional review adduced by the greater and lesser argument, and yet have been left with the belief that allocational incentives are somehow different, without being able to pinpoint that difference. ${ }^{198}$ Out of this clash of intuitions has come a variety of "balancing" or "reasonableness" tests.

The most general of these was Justice Frankfurter's reconstruction of the unconstitutional conditions doctrine in his concurrence in Watson v. Employers Liability Assurance Corp. ${ }^{199}$ Complaining that prior cases had expressed their analysis "in a jumble of loose generalizations," Justice Frankfurter undertook to winnow the grain from the chaff in some hundred opinions dealing with "so-called 'unconstitutional conditions." "201 It is not one of Frankfurter's better efforts. After four pages of exposition-it can scarcely be called analysis since it consists predominantly of block string citations quoted from earlier decisions-in which he sought to enlist Justice Holmes in his cause, ${ }^{202}$

(1976).

${ }^{197}$ See Clements v. Fashing, 457 U.S. 957, 971-73 (1982) (State's interest in preventing officeholders from vacating office before end of term is sufficient to outweigh de minimus interference with first amendment rights caused by "resign-to-run" provision.); Califano v. Aznavorian, 439 U.S. 170, 177 (1978) ("incidental effect" of denial of social security benefits on right to travel does not render it unconstitutional); Zablocki v. Redhail, 434 U.S. 374, 387 (1978) (Denial of marriage license to divorced parents who had not paid child support was unconstitutional because it "directly and substantially" interfered with the right to marry.); Califano v. Jobst, 434 U.S. 47, 5254 (1977) (denial of Social Security benefits upon marriage is acceptable despite possible impact upon decision to marry); cf. Zablocki, 434 U.S. at 408 (Rehnquist, J., dissenting) ("[T]he extent of the burden imposed by this statute [does not] so differentiate it from that considered in Jobst as to warrant a different result.").

${ }^{108}$ See supra text accompanying notes 67-97 for a discussion of the, to my mind, misgutided claim that the difference consists in the absence of coercive violence per se.

109348 U.S. 66, 78-81 (1954) (Frankfurter, J., concurring).

${ }^{200}$ Id. at 79 n.2.

201 Id. at 78 .

${ }^{202}$ Justice Frankfurter entirely ignored Justice Holmes's advocacy of the greater and lesser doctrine and cited City and County of Denver v. Denver Union Water Co., 246 U.S. 178 (1918), without so much as an intimation that the language quoted was 
Frankfurter concluded that "[t]he standard of reasonableness . . . imposed on the power of a State to admit a foreign corporation on conditions, embraces all prior instances of denial of state power." Reasonableness was to be judged by applying the test "in diverse contexts in the light of all relevant factors" to determine whether the "conditions imposed are fairly related to the interest which [the state] may appropriately protect ...."203

The test does explain the prior cases. So would any formulation that carries both a cachet of legitimacy and a quality of infinite malleability of content. But, being without content, the test yields neither guidance nor prediction; "natural justice," "what judges thought best," or "class interest"204 are equally descriptive and equally unilluminating. Yet Justice Frankfurter apparently found some bite to the concept for he relied on the prohibition of "unreasonable" conditions in dissenting from an opinion sustaining a requirement that individuals disavow affiliation with subversive organizations. ${ }^{205}$

Assuming that Frankfurter had something of substance in mind, his reasonableness requirement can in turn be reconstructed in two ways. First, reasonableness understood as rationality may be an irreducible sine qua non of legitimate government action. The difficulty is that such a requirement is either empty or a package for other values. What is reasonable for Justice Frankfurter may not be reasonable for either Justice Marshall or Justice Rehnquist. ${ }^{206}$

Second, the conclusion that a condition is reasonable may be the outcome of an incremental balancing process measuring the extent to which public interests are advanced by the condition against the degree to which constitutional rights are infringed. ${ }^{207}$ This procedure at least

written in dissent.

${ }^{203} 348$ U.S. at 82; see id. at 78 (approving the condition because it was part of a "fair bargain").

${ }^{204}$ As used by those who alternatively attribute any legal phenomenon either to exploitation by the ruling class or attempts to legitimate the entrenched regime.

${ }^{208}$ See Garner v. Board of Pub. Works, 341 U.S. 716, 724-29 (1951) (Frankfurter, J., concurring in part and dissenting in part).

${ }_{208}$ See generally Baker, Neutrality, Process, and Rationality: Flawed Interpretations of Equal Protection, 58 TEx. L. REv. 1029 (1980).

207 Indeed, one example of such balancing may be found in the employment cases. See Connick v. Myers, 103 S. Ct. 1684 (1983) (upholding the discharge of an assistant district attorney for distributing a questionnaire regarding office morale problems after a balancing of the employee's first amendment interests against the state's interest in promoting efficiency); Givhan v. Western Line Gonsol. School Dist., 439 U.S. 410, 414 (1979) (stating that a discharged employee's interests must be balanced against the state's in cases involving private speech by employees, as well as public speech); Mount Healthy School Dist. City Bd. of Educ. v. Doyle, 429 U.S. 274, 284 (1977) (whether the speech of a government employee is constitutionally protected must be determined by balancing the employee's interest in commenting on matters of public concern 
has the virtue of being a candid exercise of judicial discretion. Though a generation of critics of balancers has exposed the weaknesses of its intellectual foundations and the limits of its protection against government oppression, ${ }^{208}$ candidness and commonsense are not virtues to be sneered at. Most modern commentators on unconstitutional conditions doctrine have devoted themselves to an elaboration of precisely which factors should be balanced. Professor Van Alstyne recognizes that the Court "attempts to balance competing public and private concerns to determine whether the regulation as applied has a sufficient connection with important enough state interests to outweigh the incidental effect on the constitutional rights of the affected class."208 Professor O'Neil recommends the balancing of eight considerations, ${ }^{210}$ and $\mathrm{Mr}$. French suggests an inventory of the interests on both sides to be followed by a "weighing," a technique also suggested by Professor Westen. ${ }^{212} \mathrm{~A}$

against the state's interest in promoting efficiency of public services); Pickering v. Board of Educ., 391 U.S. 563 (1968) (same).

${ }^{208}$ See Barenblatt v. United States, 360 U.S. 109, 137-46 (1959) (Black, J., dissenting) (attacking the use of a balancing test to identify infringements of first amendment rights); Frantz, Is the First Amendment Law? - A Reply to Professor Mendelson, 51 Calif. L. Rev. 729 (1963); Frantz, The First Amendment in the Balance, 71 Yale L.J. 1424 (1962); cf. Konigsberg v. State Bar, 366 U.S. 36, $49-51$ (1961) (critiquing the view that the first amendment creates "absolute" rights).

${ }^{209}$ Van Alstyne, Right-Privilege Distinction, supra note 43, at 1449.

210 O'Neil, supra note 54, at 463-77 (whether the object of the condition could be achieved directly, whether it is germane to the purpose of the program, whether less onerous alternatives are available, the importance of the benefit to the individual, whether the benefit is a government monopoly, the psychological effect of the condition, the degree of disclosure of the condition to the victim, and the procedures by which the condition is called into effect). Because his analysis is avowedly tentative, Professor O'Neil should not be faulted. See also the stimulating discussion of Professor Shiffrin in Shiffrin, Government Speech, 27 UCLA L. REv. 565 (1980).

${ }^{213}$ See French, supra note 30, at 247. Mr. French suggests that the nature and extent of the need that called forth a government program, the scope and degree of the sovereign's interest in meeting the need, and the effect of the statute or administrative directive in furthering the state's interests should be weighed against the individual's constitutional interests, the direct and collateral effects of the state's action upon those interests, and the degree to which those elements of the program that affect the individual further the state's interests.

${ }^{212}$ See Westen, Incredible Dilemmas: Conditioning One Constitutional Right on the Forfeiture of Another, 66 Iowa L. REv. 741, 749 (1981) ("The state may condition the person's doing of $B$ on his surrender of his constitutional right to do $X$ if by doing $B$, he places himself in such a position vis-à-vis the state that his constitutional interest in asserting $X$ is outweighed by the state's interest in suppressing $X$." While Professor Westen comments in this article that "the factors bearing upon the validity of constitutional conditions are no different from the factors governing the resolution of ordinary constitutional problems," id. at 751, elsewhere he has advanced the thesis that the Supreme Court was correct in Harris v. McRae because of the difference between the allocational and criminal sanctions.); Westen, Correspondence, Regarding Perry, Why the Supreme Court was Plainly Wrong in the Hyde Amendment Case: A Brief Comment on Harris v. McRae, 32 Stan. L. Rev. 1113 (1980). 
similar potpourri seems to have been adopted by the California Supreme Court. ${ }^{213}$

An "eclectic" approach-to use Professor Shiffrin's terminology $^{214}$ - may be the only feasible analysis, but I am left with a hunger for some theoretical construct that explains why these factors, and not others, are chosen, and how they fit together. Further, I want answers to two puzzles inherent in the balancer's analysis. First, why is there a residual implication that it is relevant that restrictions on constitutional freedoms are imposed via allocational sanctions rather than criminal penalties ? $^{215}$ Why not just balance the state interest directly against the Constitution? Or, to use the test proposed by then Professor Linde, why not just ask whether a statute requiring that private employers impose the same conditions would be valid? ${ }^{218}$

Second, why does there recur in the balancer's analysis a test for the germaneness of the condition to the purpose of the benefit program? There is a consistent perception that a condition that is unrelated to the benefit is worse than a condition that is germane. ${ }^{217}$ In the normal

213 See Committee to Defend Reproductive Rights v. Myers, 29 Cal. 3d 252, 270, 625 P.2d 779, 789, 172 Cal. Rptr. 866, 876 (1981) (following a three-part inquiry: (1) whether the conditions imposed relate to the purposes of the legislation that provide the benefit; (2) whether the utility of the conditions imposed clearly outweighs the resulting impairment of constitutional rights; and (3) whether there are no less offensive alternatives available to achieve the state's objective); $c f$. Right to Choose v. Byrne, 91 N.J. $287,301-10,450$ A.2d 925, 932-37 (1982) (balancing the state's interest in protecting potential life against the mother's interest in preserving her health and in privacy and striking a statute denying state funding for nonmedically necessary abortions).

${ }^{214}$ See Shiffrin, supra note 210, at 605.

${ }_{215}$ See Clements v. Fashing, 457 U.S. 957, 978 n.2 (1982) (Brennan, J., dissenting) (suggesting that "greater deference may be due the State" because the "resign-torun" restrictions are imposed as a condition of public employment rather than directly on all employees, public or private); see also Connick v. Myers, 103 S. Ct. 1684, 1692 (1983) (allowing greater restraints upon speech rights in the context of government employment than would be permitted in the form of direct criminal sanctions); Perry Educ. Ass'n v. Perry Local Educators' Ass'n, 103 S. Ct. 948, 957 (1983) (allowing limitations on access to a public forum imposed by way of allocational sanctions that would be unconstitutional if imposed by direct sanctions).

${ }_{218}$ See Linde, Constitutional Rights in the Public Sector: Justice Douglas on Liberty in the Welfare State, 40 WASH. L. REv. 10, 76 (1965); see also id. at 43 n.304 ("T T] he validity of a governmental restraint in a publicly owned place depends on whether government could, under the same conditions, and over the same objection, validly impose the same. restraint in a similar privately-owned place.").

217 See American Communications Ass'n v. Douds, 339 U.S. 382, 417 (1950) (Frankfurter, J., concurring) ("Congress may withhold all sorts of facilities for a better life but if it affords them it cannot . . . exact surrender of freedoms unrelated to the purpose of the facilities."); French, supra note 30, at 247; Hale, Unconstitutional Conditions and Constitutional Rights, 35 Colum. L. REv. 321, 350-52 (1935); O'Neil, supra note 54, at 466-68; Reich, The New Property, 73 YALE L.J. 733, 782 (1964); Willcox, Invasions of the First Amendment Through Conditioned Public Spending, 41 CoRnell L.Q. 12 (1955); Note, Denying the Privilege Against Self-Incrimination to Public Officers, 64 HaRv. L. REv. 987, 992-93 (1951); Note, Unconstitutional Condi- 
mode of constitutional balancing, an action's acceptability depends on its relation to some governmental purpose. Why should the validity of a condition attached to a government benefit be limited by its relation to the particular purposes underlying the benefit in question? ${ }^{218}$

There is an intuitive appeal in the argument that the National Endowment for the Arts may deny funds to pointilists but not Republicans that is not accounted for by any of the theories canvassed. Since this intuition does not seem to be limited to any particular area of constitutional adjudication-or indeed to constitutional adjudication at all-it is worth trying to explain and justify. ${ }^{218}$

\section{Towards a Revised Analysis of Allocational Sanctions}

We can begin to order our intuitions by recognizing that the problem of allocational sanctions raises two distinct problems. First, viewed from the vantage of the recipient of governmental allocations, the sanction may or may not be an infringement on a constitutionally guaranteed liberty. The opportunity to receive government funding by not ex-

tions, 73 HaRv. L. REv. 1595, 1596 (1960); see also Linde, supra note 216, at 31 (speculating that claims against arbitrary disqualification might lead to a requirement of "relevance"). But cf. Stephenson v. Binford, 287 U.S. 251, 272 (1932) (even had the required relation not existed between the condition imposed and the end sought, if the state legislature concluded it did exist, the Court would defer).

${ }^{218}$ See Stewart, Pyramids of Sacrifice? Problems of Federalism in Mandating State Implementation of National Environmental Policy, 86 YALE L.J. 1196, 1250-62 (1977) (arguing that the conditions must be "necessary and proper" to achieving the objectives of the government-provided funding); Note, Unconstitutional Conditions, 73 HARV. L. REv. 1595, 1597 (1960) (basing germaneness requirement on proposition that "[r]egulation is valid only when employed to protect a social interest endangered by activity in the regulated area"). But see O'Neil, supra note 54, at 467-68 (acknowledging that if the condition is relevant to another valid state purpose, lack of relevance to the program may be "less serious").

Professor Hale's attempt to relate the test to the purpose is successful only in areas such as the taxing and commerce powers, which, at the time he was writing, permitted the federal government to act only in furtherance of sharply limited goals. Hale, supra note 217, at 352-53. Nongermaneness of a taxing program to revenue-raising cast doubt on the validity of the legislation because of the presumptive illegitimacy of regulatory motives. With modern readings of the scope of federal power and with respect to the state's plenary power to advance the public interest, such a presumption no longer exists. See, e.g., United States v. Kahriger, 345 U.S. 22 (1953); Steward Machine Co. v. Davis, 301 U.S. 548 (1937).

219 Lest one believe the key in this example is the existence of a valid state purpose in the case of the pointillist, consider the different reaction if food stamps were denied to artists who chose to be pointillists. The state's purpose is the same in both cases, but germaneness is lacking in the second one.

Professor Lyons, dealing with whether allocation decisions are coercive from the perspective of ordinary language philosophy, similarly finds the "germaneness" requirement an appealing but analytically problematic idea. See Lyons, Welcome Threats and Coercive Offers, 50 PHIL. 425 (1975). 
ercising one's constitutional rights or the possibility of exchanging one's right for some proffered benefit appears to expand, or at worst leave untouched, the sphere of individual autonomy. In this way, the allocational sanction seems different from the threat of criminal prosecution. The first issue that must be explored is the circumstances under which this appearance is illusory. My conclusion is that the distinction between liberty-expanding offers and liberty-reducing threats turns on the establishment of an acceptable baseline against which to measure a person's position after imposition of an allocation. I propose three baselines that initially test the legitimacy of allocational sanctions. And, it turns out, the relationship between the condition attached to the allocation and the purpose underlying the benefit program is of substantial import in that context.

Second, even where the allocation at issue does not reduce constitutional liberties, it may still be constitutionally unacceptable if the right involved is inalienable. The inalienability of a constitutional right turns on both the context of this offer and the nature of the right. Rather than attempt exhaustively to analyze the permutations of right and offer, I suggest the types of argument that support claims of inalienability. The applicability of particular arguments to particular rights will, of course, turn on one's underlying conception of the rights and the society they safeguard.

Finally, courts must concern themselves with what follows from the conclusion that a constitutional right has been infringed. While justifications have been offered for it, the assertion that a less strict standard of review should be applied to allocational sanctions is unwarranted. The determination that an allocational sanction has infringed a constitutional right should lead to the same process of balancing against governmental interests or the same verdict of outright impermissibility as does the determination that a constitutional right has been infringed by a direct criminal sanction.

\section{A. Of Threats and Offers}

When the National Endowment for the Arts (NEA) declines to provide subsidies for musical comedies, we do not conclude that it has infringed a right to free speech, though the decision might result in the impossibility of producing "Hair." Similarly, if it provides a subsidy for "Guys and Dolls," the NEA does not appear to infringe that right, though "Hair" may still be unavailable. However, if it provides a subsidy to every show except "Hair," or worse, if the IRS suddenly levies a prohibitive tax only on the tickets to "Hair," a claim of impingement on freedom of speech becomes more plausible. The basis for these com- 
mon sense distinctions lies not in the different impact on freedom of speech-"Hair" is unavailable in each case. Rather, the intuitive reaction rests on a comparison of each case with the situations facing the victim of the government's intervention to the situation she would have been in had the course of events proceeded normally.

A prison term, a tax, and a license revocation all lower the net advantages that a victim enjoys. By contrast, "mere" denial of benefits can be said to leave the victim no worse off than if the government had never intervened. We have the feeling that there is something coercive about the prison term, tax, and license revocation that does not infect a continuous outright denial of benefits. To threaten to move a victim below the natural baseline is, in some measure, more coercive than declining to raise her above it. Freedom is reduced in the former case but not in the latter.

In defining coercion as an alteration of the position one would have enjoyed in the normal course of events, I draw on the model used by several recent political theorists to define "freedom" and "coercion."220 The argument for so defining violations of constitutional liberties is twofold. First, these rights seek to protect individual choices. ${ }^{221}$

220 For the locus classicus of this definition of coercion, see Nozick, Coercion, in Philosophy, Science, ANd Method 440, 447 (S. Morgenbesser, P. Suppes \& M. White eds. 1969) (Coercion exists when the threatened action will make one worse off than she "would have been in the normal or natural or expected course of events."). Much has been written in tune with this theory of coercion. See, e.g., I. BERLIN, supra note 67, at 122; A. GewIRTh, Reason AND Morality 257-58 (1978); Alexander, Zimmerman on Coercive Wage Offers, 12 PHIL. \& PUB. Afr. 160 (1983); Baker, supra note 206, at 998-99; Day, Threats, Offers, Law, Opinion and Liberty, 14 AM. PHIL. Q. 257 (1977); J. FeinBerg, The Idea of A Free Man, in Rights, Justice, AND The BOUNDS OF LIBERTY 6 (1980); Frankfurt, Coercion and Moral Responsibility, in EsSAYS ON FREEDOM OF ACTION 65, 70-72 (T. Honderich ed. 1973); Lyons, supra note 219; Wertheimer, Freedom, Morality, Plea Bargaining and the Supreme Court, 8 Phil. \& Pub. Aff. 203 (1979); Zimmerman, More on Coercive Wage Offers: A Reply to Alexander, 12 PhIL. \& PuB. AfF. 165 (1983); Zimmerman, Coercive Wage Offers, 10 PHIL. \& PuB. AfF. 121 (1981).

221 The threat/offer distinction is, of course, inapplicable to the extent that we believe a given constitutional right protects not a sphere of individual autonomy but some other value. The government is not permitted to favor one religion over another, regardless of whether the favor is administered by threat or offer. Likewise, the interpretation of equal protection doctrine that traces back to a concern with the administration of laws with "an evil eye and an unequal hand," Yick Wo v. Hopkins, 118 U.S. $356,373-74$ (1886), would find irrelevant the particular variety of law to which the hand and eye turn their attention, as would equal protection and due process doctrines protecting against arbitrary decisionmaking. From this perspective, it is understandable that the first modern breaches in the judicial bulwarks against review of allocative sanctions came in the form of equal protection challenges, to which the nature of the sanction was irrelevant. See, e.g., Fowler v. Rhode Island, 345 U.S. 67 (1953) (striking down an ordinance that barred Jehovah's Witnesses from using a park that other religious groups were allowed to use); id. at 70 (Frankfurter, J., concurring) (stressing that the holding rested on the equal protection clause rather than the first amendment, 
Therefore, the evaluation of an intervention as either supporting or interfering with that right can logically enough be phrased in terms of the effect that the intervention has on the range of choices available to the victim. ${ }^{222}$ The difference between a highwayman confronting a victim with the dilemma of "your money or your life"223 and a street vendor propositioning a pedestrian with the offer of "your money or my watch" is not that the highwayman removes the possibility of choice. The bold, greedy, or foolish victim still has the choice of refusing to part with his funds at the risk of death. Rather, the distinction lies in the fact that the highwayman has narrowed the range of choices; the victim no longer has the opportunity, which existed before the intervention, of choosing to retain both money and life. The street vendor, by contrast, enlarges the range of choice. Before the offer, the pedestrian could not have chosen to make the trade. If freedom is choice, a reduction of the range of options associated with speech can be said to abridge freedom of speech in a way that an offer increasing the range of choices cannot. ${ }^{224}$

These definitions are also supported by the argument that one who is not rendered worse off by an intervention has no right to complain of it. The vendor has not harmed me in any way. Should I wish to decline his offer, I can walk away without sanction. I thus have no right to complain. The highwayman, on the other hand, significantly decreases my welfare if he carries out his threat to kill me when I refuse to give him my money. My complaint is manifest. ${ }^{225}$ This dis-

and thus did not abandon the right-privilege distinction); In re Summers, 325 U.S. 561, 571 (1945) ("Of course . . . men could not be excluded from the practice of law . . . simply because they belong to any of our religious groups .....") (dictum); Missouri ex rel. Gaines v. Canada, 305 U.S. 337, 344-45 (1938) (If a state furnishes higher education to white residents, it must provide substantially equal advantages to black residents.).

The validity of laws that violate structural constraints imposed by the Constitution does not depend on the field in which they operate, see, e.g., Immigration and Naturalization Serv. v. Chadha, 103 S. Ct. 2764 (1983); Buckley v. Valeo, 424 U.S. 1 (1976), and to the extent that the limitations of the first amendment are means to guard against government censorship that undercuts the premise of democracy, it appears irrelevant in what manner censorship is exercised. See infra note 224 and accompanying text.

${ }_{222}$ See I. BERLIN, supra note 67, at xxxix-xl, $130 \mathrm{n} .1$ (one's range of choices is the measure of her freedom); Day, supra note 220, at 259-62; J. FEINBERG, The Interest in Liberty on the Scales, in RIGHTS, JUSTICE AND THE BOUNDS OF LIBERTY 36-38 (1980).

${ }^{223}$ This example is tattered by decades of use, see, e.g., C. Fried, ConTract as Promise 95 (1981); Nozick, supra note 220, at 453 , but it is still illuminating.

${ }_{224}$ See, e.g., Griswold v. Connecticut, 381 U.S. 479, 482 (1965) ("IT]he State may not . . . contract the spectrum of available knowledge.").

${ }^{225}$ Professor Nozick suggests that the crucial question is whether the highwayman has made me an offer I would have preferred not to have been made. See Nozick, supra note 220 , at 459 . When this is the case, the highwayman's will has in effect been 
tinction between threats and offers gives an initial answer to the otherwise troubling question of why, in the first instance, a plausible distinction can be drawn between criminal and allocative sanctions. A criminal sanction is in most cases an unambiguous threat, for the normal course of events in the absence of such a sanction is not incarceration or payment of a fine. ${ }^{226}$ Whether an allocation involves a threat or an offer, by contrast, is a more difficult question.

As a number of commentators have noted in different contexts, the words "normal course of events" mask an array of difficulties. ${ }^{227}$ Take, for example, the case of Speiser v. Randall, ${ }^{228}$ Justice Brennan's earliest venture into the field of allocative sanctions. There, the Court reviewed a provision of the California constitution denying tax exemptions to individuals and institutions that advocated the overthrow of the government by unlawful or violent means. As applied to plaintiffs who refused to certify their qualifications, the provision resulted in the denial of a veteran's property tax exemption on the first $\$ 1000$ worth of

substituted for my own, and I have been used for another's ends. For my purposes here, this argument is not central.

Professor C. Edwin Baker, in private conversation, has suggested to me that since any reduction in wealth reduces the scope of options that would otherwise have been available to the victim, when the reduction violates the right to a proportional share of those benefits to which all citizens are morally entitled, it should be regarded as a coercive, and hence unconstitutional, limitation on other constitutional rights that protect liberty, such as the right of free speech.

I disagree with Professor Baker on this point. While it is certainly true that the deprivation of wealth reduces the victim's options, she is not worse off than she otherwise would have been because of the exercise of her constitutional rights. There is a difference between the highwayman depriving me of my watch at gunpoint and his depriving me of my cash, as a result of which I am forced to sell my watch. My retention of the watch in the former instance would result in my being significantly worse off than I would have been in the normal course of events (i.e., dead). In the latter case, whether or not I decide to retain my watch, I am worse off to the degree of the initial deprivation. It is awkward to say that the highwayman has deprived me of my watch. The other line of argument that supports the same intuition is that in the former case, the highwayman has control over whether or not I retain my watch and hence is clearly responsible for my losing it, while in the latter, whether I sell my watch, my shoes, or my tie is beyond the control of my assailant.

${ }^{226}$ Of course, where the normal course of events is incarceration, as in the case of plea bargains, a lesser prison term may constitute an offer rather than a threat. See, e.g., United States v. Goodwin, 457 U.S. 368, 379 (1982) (" '[A]dditional' charges obtained by a prosecutor [cannot] necessarily be characterized as an impermissible 'penalty.'. . . [C] ]harges brought in an original indictment may be abandoned by the prosecutor in the course of plea negotiation-in often what is clearly a 'benefit' to the defendant ... . "); see also Greenberg, Probation Conditions and the First Amendment: When Reasonableness Is Not Enough, 17 Colum. J.L. \& Soc. Prors. 45 (1981) (offering an excellent overview of the courts' reactions to offers of probation conditioned on impositions on constitutional rights).

227 C. FRIED, supra note 223, at 95-95; Alschuler, The Changing Plea Bargaining Debate, 69 CALIF. L. REv. 652, 658-60 (1981); Nozick, supra note 220, at 447-53.

228357 U.S. 513 (1958). 
personal property. In striking down the denial, Justice Brennan began his analysis with the comment that "[t]o deny an exemption to claimants who engage in certain forms of speech is in effect to penalize them for such speech. Its deterrent effect is the same as if the State were to fine them for this speech."229 On its face, this looks straightforward enough, and Justice Brennan's argument has been often repeated. ${ }^{230}$ Closer examination, however, takes us into a hall of mirrors.

If the "deterrent effect" of a fine is a direct function of the income or wealth foregone, any refusal to provide income has such an effect. The government that offers to buy advertising time for anti-cigarette commercials for $\$ 1000$ but that declines to pay when the offer is not accepted produces the same deterrent effect as a regime that fines $a^{\text {' }}$ network $\$ 1000$ for not running a similar advertisement gratis. ${ }^{231}$

There are, however, differences both normative and positive. People do, ${ }^{232}$ and should, regard the two deterrents differently. The first seems to be an example of bargaining, the second, one of "coercion." The force of Justice Brennan's position is his assignment of the California provision to the second category; the denial of the exemption is, he says, a penalty.

But why a penalty to veterans who refused to take the oath and not a "bonus for loyalty" to veterans who did, as the California Supreme Court characterized the exemptions granted to oath takers?233 If the normal situation is exemption from taxes for all taxpayers, the denial of an exemption results in a tax, leaving the noncomplying taxpayers worse off. On the other hand, Californians do pay property taxes.

229 Id. at 518.

230 See, e.g., Elrod v. Burns, 427 U.S. 347, 359 (1976); Sherbert v. Verner, 374 U.S. 398, 405-06 (1963); see also Shapiro v. Thompson, 394 U.S. 618, 629 (1969) (one-year waiting period before immigrants become eligible for welfare deters interstate travel).

281 I leave aside the possibility that the gain or loss of $\$ 1000$ will substantially alter the network's preferences. The wealth effects of such small amounts are likely to be minimal.

${ }^{232} \mathrm{~J}$. Bentham, AN Introduction to the Principles of Morals and LegISLATION 3 n.a (1970) ("It is worse to lose than simply not to gain.") (emphasis omitted); Kahneman \& Tversky, The Psychology of Preferences, ScI. AM., Jan. 1982, at 160-73.

233 See First Unitarian Church v. County of Los Angeles, 48 Cal. 2d 419, 438, 311 P.2d 508, 520 (1957), rev'd, 357 U.S. 545 (1958) ("[T] his legitimate objective [of encouraging loyaltyl is sought to be accomplished by placing in a favored economic position ... those particular persons and groups of individuals who are capable of formulating policies relating to good morals and respect for the law."); $c f$. Minneapolis Star \& Tribune Co. v. Minnesota Comm'r of Revenue, 103 S. Ct. 1365, 1376 (1983) ("[W]hen [an] exemption selects . . . a narrowly defined group to bear the full burden of [a] tax, the tax begins to resemble more a penalty for [the few burdened taxpayers] than an attempt to favor [those taxpayers who are exempted]."). 
Having refused to swear that he did not advocate the government's overthrow, Mr. Speiser was no worse off than most of his fellow citizens. The government, after all, did not have to exempt veterans. Speiser was, of course, worse off than veterans who signed the oath, but the network that declines to run the ad seems to be worse off, and it was not coerced. To explain the distinction between the two situations, we must specify the appropriate baseline or position against which to compare the victim's position after governmental intervention. ${ }^{234}$

One possibility is the "existential counterfactual:"23s Is the victim worse off than if the government had never existed ${ }^{238}$ Compare with Speiser the situation of a Philadelphia newspaper that finds advertisements traditionally placed by the city withdrawn because of a series of stories critical of the mayor's conduct. ${ }^{237}$ Obviously, if there were no city, there could be no ads. Hence, when the ads are pulled, the newspaper is no worse off than if the city had never existed. By contrast, if California did not exist, Speiser would pay no taxes. He is worse off.

However, there are manifest difficulties here, for the argument proves too much and too little. If Hobbes is right, anything beyond a poor, nasty, brutish, and short life still leaves the victim better off than if the government had not existed. ${ }^{238}$ For most victims, the deprivations that would count as infringements on constitutional rights would be limited to summary executions. On the other hand, if the victim is a

2s4 Professor Clark suggests the necessity of a zero point or status quo ante by reference to which we can judge whether state intervention is action or inaction. See Clark, supra note 138, at 1017-19. He never explains how the status quo should be identified (although he mentions temporal, predictive, and counterfactual considerations) or why it is necessary.

28s For a basic discussion of counterfactuals, see N. Goodman, Fact, Fiction, AND Forecast (1973).

2s6 See Alexander, Liberalism as Neutral Dialogue: Man and Manna in the Liberal State, 28 UCLA L. REv. 816, 837 (1981) (suggesting that "the correct approach for a libertarian" is to adopt the principle that "B cannot end up better off were B in a world without A through an award of [resources] that makes A worse off than were $A$ in a world without B").

The Court has at times engaged in counterfactual speculations. See United States Postal Serv. v. Council of Greenburgh Civic Ass'ns, 453 U.S. 114, 123-24 (1981), in which Justice Rehnquist suggested that the civic association would be far worse off if no postal service existed than it is having to pay postage costs to use mailboxes; see also Hammer v. Dagenhart, 247 U.S. 251, 281 (1918) (Holmes, J., dissenting) ("If there were no Constitution and no Congress, [the states'] power to cross the [state] line would depend upon their neighbors.").

237 See Frissell v. Rizzo, 597 F.2d 840 (3d Cir. 1979). Once again, the tactic is not a new one. During the first half of the nineteenth century, United States Presidents, beginning with Thomas Jefferson, used government printing contracts and advertising to support or encourage favorable press coverage. F. MOTT, AMERICAN JourNaLisM 178 (1941); I. de Sola Pool, Technologies of Freedom 78 (1983).

ass See T. Hobbes, Leviathan 104 (rev'd Amer. ed. 1950). 
Hobbesean survivor-let us say a black belt in karate or a lineman for the Denver Broncos-denying the individual what he would be able to seize or hold in the state of nature would be coercive. ${ }^{239}$ Hobbes may not be right, ${ }^{240}$ but we have no way of knowing. This is the shortcoming of the existential counterfactual as a baseline; in our world, the government does exist, and we lack the theoretical or investigative apparatus to determine what the world would look like in its absence. This also is the flaw in Justice Powell's suggestion in Maher v. Roe $e^{241}$ that "[the state] has imposed no restriction on access to abortions that was not already there."242 Without the state, we have no idea of what would be "already there."

If not Hobbes, what of Locke? Equipped with a strong enough theory of natural rights that antecede the establishment of government, we could denote the deprivation of those rights, or the failure to extend or protect them, as an illegitimate inducement to forego a constitutional right. But at this point, the existence of the constitutional right is superfluous. Everything turns on whether there is a natural right to the benefit in question, and the impact of the deprivation on other constitutional rights is irrelevant. If there is a natural right to obtain advertising, the failure to purchase advertising because of fiscal constraints is as impermissible as the refusal to purchase advertising because of criticism by the press.

Under such a theory, to answer the question of allocational sanctions, one would have to construct a comprehensive system of moral entitlements to government allocations. The failure of consensus regarding theories of distributive justice in other areas bodes ill for such an enterprise. Moreover, for purposes of the problem before us, such a comprehensive system may be both unnecessary and misleading. The fact that no one has yet argued for the creation of a right to receive city-sponsored advertisement does not intuitively disqualify the newspaper's claim that Mayor Rizzo cannot cut off city advertisements in retaliation for criticism. The newspaper appears to say something credible when it claims an abridgment of its first amendment rights. What is it?

Our problem, at least in separating threats from offers, lies in the

${ }^{239} C f$. J. Buchanan, The Limits to Liberty 47-50, 77 (1975) (seriously advancing the proposition that the legitimate distribution of property in a society corresponds to the "threat advantage" of the participants in the state of nature).

${ }^{240} C f$. E. Gellner, Muslim Society (1983) (describing a society in which the role of the state as protector of its citizens is limited and clan hierarchies are the basic guardians of individual freedoms and property).

241432 U.S. 464 (1977).

243 Id. at 474. 
challenge to specify an appropriate normal course of events from which to judge deviations. While no single baseline is determinative, three together express the relevant factors. An action that pushes a victim below the position she would have occupied on all three scales is easily characterized as a coercive threat subject to full constitutional scrutiny. An action that raises its subjects above the normal course of events, as characterized by all three baselines, is recognizable as an offer free from the limits on coercive government authority. Where the scales conflict, we confront difficult cases.

\section{History as a Baseline}

If it is difficult, both practically and conceptually, to distinguish action from inaction in allocative contexts, ${ }^{243}$ it is nonetheless practicable to distinguish change from inertia. Losing a benefit previously provided seems different from simply never having been provided the benefit in the first place. If for each of the last twenty years the mayor has provided city patronage to the advertising department of a newspaper, the threat to stop doing so unless the newspaper changes its editorial policy would legitimately be viewed as coercion. On the other hand, if the mayor announces the intention to provide previously unavailable advertising revenues conditional on a change in policy, the announcement, while perhaps unconstitutional on other grounds, does not seem at first glance like a threat to penalize the existing policy, for it does not reduce the range of choices available to the newspaper.

The use of the status quo ante as the baseline from which to judge allocation decisions runs through a number of recent opinions. Most prominently, the freedom of the government to allocate access to government facilities has turned in recent years on whether such facilities are historical "public fora."244 In areas that "by long tradition . . . have been devoted to assembly and debate,"245 like streets and parks that have "immemorially been held in trust for the use of the public and, time out of mind, have been used for purposes of assembly, communicating thoughts between citizens, and discussing public questions, "248 any limitation on the exercise of first amendment rights is

24s See supra text accompanying notes 98-105.

244 See, e.g., Perry Educ. Ass'n v. Perry Local Educators' Ass'n, 103 S. Ct. 948 (1983); California v. Grace Brethren Church, 457 U.S. 393 (1982); Widmar v. Vincent, 454 U.S. 263 (1981); United States Postal Serv. v. Council of Greenburgh Civic Ass'ns, 453 U.S. 114 (1981). (1983).

245 Perry Educ. Ass'n v. Perry Local Educators' Ass'n, 103 S. Ct. 948, 954

${ }^{216}$ Hague v. CIO, 307 U.S. 496, 515 (1939) (opinion by Roberts, J.). 
presumptively unconstitutional, for the limitation reduces the range of freedom of speech and assembly in comparison to the freedom available before. By contrast, on government property that is newly opened to the public, speech and assembly can be limited because the opening of the new forum-even to a limited extent-increases the range of expressive activity available over the historical baseline. ${ }^{247}$ In either situation, what is at issue is not the hypothetical uses to which the property could be put, but the concrete history of the forum at issue. ${ }^{248}$ In such situations, the court at least nominally adopts Justice Holmes's suggestion that "a page of history is worth a volume of logic."249

247 Indeed, this in part explains the dedicated forum doctrine. Because the government is creating a forum that is, from the start, restricted to particular uses, the opportunities for expressive activities are being increased rather than cut back. See Minnesota State Bd. v. Knight, 104 S. Ct. 1058, 1064-70 (1984) (allowing university to "meet and confer" with only the representatives of its employee association because the statute ordering it to do so does not create a forum for nonmembers of the employee association to "meet and confer" with the university); Greer v. Spock, 424 U.S. 828 (1976) (because of the special nature of a military base into which only selected speakers were invited, government need not allow political campaigning that might be disruptive); Buckley v. Valeo, 424 U.S. 1, 92-93 (1976) (per curiam) (upholding provision of the Federal Election Campaign Act of 1971 that provides funding only to major parties because it "is a congressional effort, not to abridge, restrict, or censor speech, but rather to use public money to facilitate and enlarge public discussion and participation in the electoral process").

Minnesota State $B d$. is a problematic example, however, because before the adoption of the statute in issue, the authorities consulted with both members and nonmembers.

${ }^{248}$ See, e.g., United States v. Grace, 103 S. Ct. 1702, 1708 (1983) ("Traditional public forum property occupies a special position in terms of First Amendment protection and will not lose its historically recognized character for the reason that it abuts government property that has been dedicated to a use other than as a forum for public expression."); United States Postal Serv. v. Council of Greenburgh Civic Ass'ns, 453 U.S. 114, 133 (1981) ("Congress . . . may not by its own ipse dixit destroy the 'public forum' status of streets and parks which have historically been public forums . . . ."); Lehman v. City of Shaker Heights, 418 U.S. 298, 302 (1974) ("'[B]efore you could say whether a certain thing could be done in a certain place you would have to know the history of the particular place." ") (quoting Lord Dunedin in M'ara v. Magistrates of Edinburgh, 1913 Sess. Case, 1059, 1073-74) (Scotland).

240 United States Postal Serv. v. Gouncil of Greenburgh Civic Ass'ns, 453 U.S. 114, 120-21(1981) (quoting New York Trust Co. v. Eisner, 256 U.S. 345, 349 (1921)). Unfortunately, having announced his allegiance to history, Justice Rehnquist proceeded to ignore it. His opinion treats the criminal prohibition of placing unstamped matter in a postal box, adopted in 1934, as an integral part of the postal system necessary to protect against "activities . . . wholly incompatible with the maintenance of a nationwide system for the safe and efficient delivery of mail." Id. at 130 n.6. He fails to mention that, from 1790 to 1934 , the system survived without the statute, the enactment of which clearly must have decreased the range of possible first amendment activities.

A similar one-eyed view of the status quo ante infected Justice White's opinion in Perry Educ. Ass'n v. Perry Local Educators' Ass'n, 103 S. Ct. 948 (1983), in which an agreement excluding PLEA, the rival union, from access to employee mailboxes to which they had previously had access, was upheld. Justice White dismissed PLEA's 
A similar conviction explains Justice Brennan's position distinguishing removal of a book from a library shelf from failure to purchase that book in the first place. ${ }^{250}$ The removal reduces the range of choice available to students, as compared to the historical baseline, while the failure to purchase a book leaves unchanged the information available. $^{251}$

The strength of the historical baseline is its grounding in the real world. Whether or not a benefit has been dispensed in the past is an historical fact. Rather than introducing implicit assumptions about the political viability of particular actions, as do the greater and lesser argument and the anthropomorphic purpose analysis, or speculating about whether the state could have denied benefits entirely in the past, the historical baseline focuses on whether the state in fact did so. If the benefit has not been previously provided, selective failure to provide it now is a politically proper subset. The state has exercised the greater power in the past, and it is plausible to suggest it can do so in the future. Thus, the political underpinning of the greater and lesser argument has a basis in experience. On the other hand, the fact that the benefit has been available casts doubt on a claim that the denial neither expands government power, nor reduces citizen options. The status quo carries within itself its own defense: it is costly for the government to devote its resources to altering the current situation. Change, by contrast, requires justification. ${ }^{252}$ It is always a legitimate question for a citizen to ask why she is being treated differently from her

argument that its prior access to the school mail facilities had rendered them a limited public forum by pointing out that, at that time, the union was not the rival of the exclusive bargaining representative and therefore "had legitimate reasons for use of the system." Id. at 956. Apparently, PLEA's new status as rival to the dominant union made its history of free access irrelevant.

${ }^{280}$ See Board of Educ. v. Pico, 457 U.S. 853, 871 (1982) ("[N]othing in our decision today affects in any way the discretion of a local school board to choose books to add to the libraries of their schools.").

${ }^{251} C f$. Plyler v. Doe, 457 U.S. 202, 227 n.22 (1982) (rejecting the state's attempt to characterize its exclusion of illegal alien children from the schools as a "residence test," by changing its historical test of residency, under which illegal aliens would have qualified as residents); Califano v. Jobst, 434 U.S. 47, 50-55 (1977) (defending elimination of disability benefits upon marriage to a nonrecipient of benefits by stressing that the provision of such benefits had occurred as a gradual expansion of the program over a period of years); Speiser v. Randall, 357 U.S. 513 (1958) (striking a requirement that veterans take a loyalty oath to qualify for tax exemption, when the exemption had previously been available without the taking of an oath); Western Union Tel. Co. v. Kansas, 216 U.S. 1, 33 (1910) (striking statute requiring that foreign corporations pay charter fee to qualify to do business in the state, when no such fee had been exacted previously).

285 See G. Perelman, LAw and ARgument, supra note 54, at 91 ("[O]nly change, always, everywhere and in anything, requires justification."); see also id. at 159. 
predecessors.

So, too, a citizen may reasonably come to rely on past practice and justifiably regard a change as a deprivation, different in kind from a mere failure to provide a benefit. Once the government decides upon a course of action, it should be held to account for the impact of its decision on constitutional rights. As Justice Holmes commented on the government's "declining to provide the benefit" of postal service,

The decisions thus far have gone largely if not wholly on the ground that if the Government chose to offer a means of transportation which it was not bound to offer it could choose what it would transport; which is well enough when neither law nor the habit that the Government's action has generated has made that means the only one. But when habit and law combine to exclude every other it seems to me that the First Amendment in terms forbids such control . . . . ${ }^{253}$

And government's disavowal of responsibility for a given outcome sounds more plausible if that government has never intervened in the field at all than if it suddenly withdraws.

Finally, there is a recurring philosophical and psychological perception that losing a good is worse than not receiving it. ${ }^{254}$ The vision of nonexistence resulting from death is much more troubling than the fact of nonexistence before birth, ${ }^{255}$ and a brain injury that reduces an adult to the level of a three-month old seems more tragic than a birth defect that prevents any further development. ${ }^{256}$

It must be admitted that, taken alone, the historical baseline is not a sharp-edged analytical tool. If one government official grants benefits, only to be reversed by her superiors, has a baseline been established? If not, how long must the allocation persist to qualify as the status quo? On another tack, if the government is not to be permanently straitjack-

2ss Leach v. Carlile, 258 U.S. 138, 141 (1922) (Holmes, J., dissenting). See also United States ex rel. Milwaukee Soc. Democratic Publishing Co. v. Burleson, 255 U.S. 407, 437 (1921) (Holmes, J., dissenting) ("The United States may give up the Post Office when it sees fit, but while it carries it on the use of the mails is almost as much a part of free speech as the right to use our tongues .....").

25s See, e.g., Kahneman \& Tversky, supra note 232, at 160-73; Kahneman \& Tversky, Prospect Theory: An Analysis of Decision Under Risk, 47 EconomeTriaA 263 (1979); Slovic \& Lichtenstein, Preference Reversals: A Broader Perspective, 73 AM. Econ. Rev. 596, 600 (1983); Thaler, Toward a Positive Theory of Consumer Choice, 1 J. Econ. Behavior and Organization 39 (1980).

255 See J. Bentham, supra note 232, at 3 n.a (emphasis omitted); T. NageI, MoRTal Questions 8-10 (1979); White, Negative Liberty, 80 Etrics 185, 188-93 (1970) (distinguishing the kinds of situations in which it can be said "that a person is unfree to do something because it is-or has been made-impossible for him to do it").

268 T. NAGEL, supra note 255 , at 5-6. 
eted, changes in surrounding circumstances must in some instances be sufficient to allow the government to start over again. Conversely, the historical baseline provides no initial protection to citizens in the context of changing social or technological conditions that necessitate or facilitate the provision of new benefits. These difficulties dull but do not entirely blunt the persuasive force of history. They do suggest, however, that other factors must be considered. ${ }^{257}$

\section{Equality as a Baseline}

Even if there were no history of public advertising, the mayor's decision not to place advertising in one paper while placing it in all others looks significantly different from a decision simply not to place ads. Similarly, Mr. Speiser's exclusion from benefits accorded other veterans because of his failure to disavow membership in subversive organizations looks like a penalty even if veterans' property were previously fully taxable.

The normal course of events, under this interpretation, is the course of events that is the statistical norm: what happens to everyone else. Thus, for example, in Zobel $v$. Williams, ${ }^{258}$ Justice Rehnquist could suggest that interstate travel to Alaska was not deterred by a grant of oil revenues proportional to the length of residency by implicitly comparing the grant to a newcomer to the immigrant's situation in his previous residence. ${ }^{259}$ Viewed in comparison with the benefits granted to established residents, however, the program was interpreted by Justices Brennan, Marshall, Blackmun, and Powell as a penalty

${ }^{267}$ Professor Clark, in Legislative Motivation and Fundamental Rights in Constitutional Law, 15 SAN Diego L. REv. 953, 1023 (1978), rejects the historical baseline for three reasons. First, he suggests that it would establish an "essentially arbitrary difference between communities." For the reasons given in text, see supra text accompanying notes 252-56, the difference in history seems far from arbitrary. Second, he argues that such a baseline would be misleading because the motivation of the entity in question can be disguised to evade the Court's objections. This, however, would only be the case if motivation were, in fact, the touchstone of constitutionality. For reasons mentioned above, see supra text accompanying notes $135-64$, I believe that motivation analysis is largely misguided. Third, Professor Clark suggests (as does Justice Burger's dissent in Board of Educ. v. Pico, 457 U.S. 853 (1982)) that the historical baseline would "freeze the community" into an irreversible decision, once a program were undertaken. One solution to this difficulty is to allow the presumptive validity of an historical baseline to be impeached by changes in circumstances. Absent such changes, however, the baseline would stand. A second response-given in text-is that considerations of history must be combined with those of equality and prediction to set the baseline. Finally, it may be that this is simply the price that must be paid. It is not unreasonable to require a greater justification for decisions that decrease the options for the exercise of constitutional rights than those that increase the options.

268457 U.S. 55 (1982).

269 See id. at 83 (Rehnquist, J., dissenting). 
that made those who exercised the right of interstate travel worse off than those who had not. ${ }^{260}$ Similarly, the line of cases following from Police Department v. Mosley, ${ }^{261}$ which granted the government a theoretical right to prohibit picketing or other first amendment activity in certain areas but barred it from selectively prohibiting such activities in only some of the areas, sets a baseline of equality. Exclusion of all speech leaves one no worse off than she would have been in the normal course of events, while exclusion of only some speech makes the disfavored speech worse off than the favored. Similarly, the importance of history as a baseline in the public forum cases may in part result from the claim of present citizens that they have a right to be treated on an equal basis with their predecessors.

These examples are not isolated ones. If, as Justice Rehnquist suggested in Clements $v$. Fashing, ${ }^{262}$ it would be a "perversion of the Equal Protection Clause were we to conclude" that when a state exercises conceded powers to contract the scope of autonomy rights, it must do so uniformly, then the Court has indulged in a veritable orgy of equal protection analysis. ${ }^{263}$ To deprive a citizen of a benefit available

260 See id. at 76 n.6 (O'Connor, J., concurring) ("The 'burden' imposed on nonresidents is relative to the benefits enjoyed by residents.").

261408 U.S. 92 (1972). See Widmar v. Vincent, 454 U.S. 263 (1981); Garey v. Brown, 447 U.S. 455 (1980); Healy v. James, 408 U.S. 169 (1972); Grayned v. City of Rockford, 408 U.S. 104 (1972).

262457 U.S. 957,969 (1982).

${ }^{203}$ See Zobel, 457 U.S. 55 (striking grant program that discriminated in favor of longterm residents); Thomas v. Review Bd., 450 U.S. 707 (1981) (state may not deny unemployment benefits to one who quits her military-related civilian job because it conflicts with her religious beliefs); Memorial Hosp. v. Maricopa County, 415 U.S. 250 (1974) (state may not set up a one-year durational residency requirement for eligibility for free medical care); Police Dep't v. Mosley, 408 U.S. 92 (1972) (city may not prohibit only certain kinds of peaceful picketing); Shapiro v. Thompson, 394 U.S. 618 (1969) (state may not deny welfare benefits to otherwise eligible persons who have not lived in the state for one year); see also Karst, Equality as a Central Principle in the First Amendment, 43 U. CHI. L. Rev. 20 (1975).

A majority of the court in a number of recent cases has tended to separate artificially the equality analysis from the analysis to determine whether a protected right has been infringed. See, e.g., Regan v. Taxation with Representation, 103 S. Ct. 1997 (1983) (by granting a tax exemption to veterans' organizations that lobby while denying an exemption to other nonprofit organizations that lobby, Congress merely declined to fund the exercise of certain organizations' first amendment rights, therefore no constitutional right is infringed and the classification is only subject to minimum rationality review under the equal protection clause); Perry Educ. Ass'n v. Perry Local Educators' Ass'n, 103 S. Ct. 948, 957 (1983) (because there is no "obligation per se to let any organization use the mailboxes," refusal to extend the privilege granted to the established teachers' union to its rival need not be evaluated by strict equal protection scrutiny); Clements v. Fashing, 457 U.S. 957, 960 (1982) (because the "resign-to-run" statute is not a "significant barrier" to the exercise of political rights "it is no argument that . . . it burdens only [certain] office holders"); $c f$. Minneapolis Star \& Tribune Co. v. Minnesota Comm'r of Revenue, 103 S. Ct. 1365, 1379 (1983) (Rehnquist, J., dis- 
to those who are similarly situated because of her exercise of constitutional rights is to impinge on protected liberties.

The principle of equality of distribution as the baseline from which allocational decisions can be judged has one root in principles of virtual representation. As Professor Kalven argued,

The point should have considerable practical significance. Everyone at some time or other loves a parade whatever its effect on traffic and other uses of public streets. Municipalities pressed by concern with the protest movement may be inhibited in any rush to flat nondiscriminatory prohibitions by the difficulty of distinguishing between the parades we like and others. Equal protection may, therefore, require freedom for the parades we hate. ${ }^{264}$

Equality of treatment can also be seen as a moral requirement, necessary to achieve a society that accords equal respect to its citizens, ${ }^{285}$ for the presumption of equality of treatment, absent reasons to the contrary, is deeply rooted in the traditions of liberal democracy. Moreover, a peculiar psychological pain attaches to being singled out or

senting) ("To my knowledge this Court has never subjected governmental action to the most stringent constitutional review solely on the basis of 'differential treatment' of particular groups."); see also Harris v. McRae, 448 U.S. 297 (1980) (upholding denial of abortion funding to medicaid recipients despite inequality between ability of poor and better-off women to obtain pregnancy-related medical procedures); Maher v. Roe, 432 U.S. 464 (1977) (same).

Such analysis fails to recognize that claims of equality themselves may set the baseline for determining whether the right has been infringed. Whether the allocation in question is an offer or a penalty depends on the validity of claims that the allocation has been unequal.

204 Kalven, The Concept of a Public Forum: Cox v. Louisiana, 1965 SuP. Cr. Rev. 1, 30.

${ }_{260}$ See, e.g., B. Ackerman, Social Justice in the Liberal State 55-58, 168$69,238-39$ (1980) (arguing that equality is always justifiable in neutral dialogue by reference to equality of personhood, while inequality requires justification); A. GuTMANN, LIBERAL EQUALITY 12, 104, 106, 170, 222 (1980) (arguing that equality of persons is a basic presupposition of liberal political theory); see also R. DworkIN, TAKING Rights SERIOUSLy (1977); Baker, Outcome Equality or Equality of Respect: The Substantive Content of Equal Protection, 131 U. PA. L. Rev. 933 (1983); Baker, supra note 206; Karst, In Defense of Equality, 17 GA. L. REv. 245, 248 (1983) (arguing that equality is necessary to preserve "the chief citizenship value [of] respect"); see also Hewitt v. Helms, 103 S. Ct. 864, 879 (1983) (Stevens, J., dissenting) ("TThe due process] clause is implicated when the State singles out one person for adverse treatment . . . . For an essential attribute of the liberty protected by the Constitution is the right to the same kind of treatment as the State provides to other similarly situated persons.") (footnote omitted); Plyler v. Doe, 457 U.S. 202, 213 (1982) ("The Equal Protection clause was intended to work nothing less than the abolition of all caste-based and invidious class-based legislation."); Zobel, 457 U.S. at 71 (Brennan, J., concurring) (With respect to discrimination based on the length of residency within a state, the Court has rejected the notion that "some citizens are more equal than others." "). 
pointedly excluded. ${ }^{268}$ Similar treatment can always be justified by reference to the equality of persons; it insults no one. Differences in treatment require further explanation. ${ }^{267}$

Despite the central role of equality in our political traditions, a particular objection can be raised to its use as a baseline for assessing the constitutionality of allocational sanctions. It is generally agreed that in the field of criminal sanctions the state may not selectively burden the exercise of constitutional rights. However, some argue that in any allocation decision, inequality is inevitable. If the resources to be allocated are limited, some potential recipients must, by definition, be denied, and the cut-off point may well be random. ${ }^{288}$ Thus, using equality as the baseline for allocation decisions involves a difficulty that does not arise with criminal prohibitions. ${ }^{269}$

Courts should be cautious in using this rationale, however, for there are instances where it is manifestly inapplicable. In situations where there is no real resource cost to including all of the proposed class, the government cannot justify excluding part of that class by arguing that it must make choices. Where public good is involved and the provision of the benefit to additional recipients would be no more costly than the provision to the initial recipient, ${ }^{270}$ or where the cost of providing the benefit has already been expended, ${ }^{271}$ or where provision of

$286 \mathrm{~J}$. FeInBerg, Noncomparative Justice, in Rights, JUSTICE, AND THE BOUNDS OF LIBERTY 286 (1980). (1955-56)

${ }^{267}$ See generally Berlin, Equality, 56 Proc. of THE ArIStotelian Soc'y 301

${ }^{268}$ See Board of Educ. v. Pico, 457 U.S. 853, 878 n.1 (1982) (Blackmun, J., concurring) (stating his belief that standard created for dealing with library book removals is not applicable to curricular decisions because "[ $t]$ he school's finite resources . . . require that education officials make sensitive choices . . . ; subjects generally are excluded simply because school officials have chosen to devote their resources to one rather than another subject"); Widmar v. Vincent, 454 U.S. 263, 276 (1981) (court does not "question the right of the University to make academic judgments as to how best to allocate scarce resources or 'to determine for itself on academic grounds who may teach, what may be taught, how it shall be taught, and who may be admitted to study.' ") (quoting Sweezy v. New Hampshire, 354 U.S. 234, 263 (1957) (Frankfurter, J., concurring)); Schwieker v. Wilson, 450 U.S. 221, 238 n.23 (1981) ("When a legal distinction is determined, as no one doubts that it may be, between night and day, childhood and maturity, or any other extremes, a point has to be fixed or a line has to be drawn . . . to mark where the change takes place.") (quoting Louisville Gas Co. v. Coleman, 277 U.S. 32, 41 (1928) (Holmes, J., dissenting)).

${ }^{260}$ Cf. C. FrIED, supra note 77, at 37-38.

270 See, e.g., Southeastern Promotions, Ltd. v. Conrad, 420 U.S. 546 (1975) (holding that a city's refusal to lease its auditorium, which had already been constructed, to a theatre company that wished to present the musical "Hair" in it violated the first amendment).

${ }^{271}$ See, e.g., Board of Educ. v. Pico, 457 U.S. 853 (1982) (removal of library books that had already been purchased violated the first amendment if done with intent to suppress ideas). 
the benefit will in fact save resources, ${ }^{272}$ the validity of the baseline of equality cannot be challenged with a claim that linedrawing is inevitable. Even when the provision of the benefit to additional recipients entails real resource costs, the necessity for choice does not negate the claims of equality.

Not all inequalities are equally offensive, and the government may recognize some claims to limited resources without diverging from the appropriate baseline. Our reactions differ significantly depending on whether the victim's position is unlike that of most others who are similarly situated or whether her position is comparable to that of the majority of other members of her class. The force of a claim that equal allocations of benefits represent the normal course of events turns on the prevalence of the benefit.

If, rather than excluding the offending paper from access to city advertising, the mayor gives a "best paper of the year" prize to one of ten competing newspapers-the one that has been most favorable to the city in its reporting - an inequality certainly exists between the winner and the losers. However, it is difficult to characterize this inequality as a penalty to the losers.

On the other hand, the more a government's necessary choices tend to single out for exclusion from otherwise available benefits those who exercise a particular right, the more that choice appears to penalize that exercise. As Professor Chafee put the matter,

[a] testator is not obligated to leave property to his children at all in many states; but if he divides his estate among all his children except one, this is morally a penalty on the omitted child. You cannot argue to the child who is cut out of the will that he has merely failed to receive a favor. ${ }^{273}$

Thus, in Widmar $v$. Vincent, ${ }^{274}$ Justice Powell emphasized the discriminatory exclusion of only religious exercises from the use of facilities that were generally available for other activities. ${ }^{276}$ And in $\mathrm{Ply}$ -

272 See, e.g., Harris v. McRae, 448 U.S. 297 (1980) (Congress's refusal to expend Medicaid funds for abortions results in the expenditure of funds for childbirth, which is more costly).

273 Z. Chafee, 1 Government and Mass Communications 306 (1947). See also Z. Chafee, 2 supra, at 709-10 (1947).

274454 U.S. 263 (1981).

${ }^{278}$ Id. at 273 ("[T] he question is whether [the college] can now exclude groups because of the content of their speech."); see also Healy v. James, 408 U.S. 169 (1972) (A university may not deny use of its facilities to the Students for a Democratic Society because of disagreement with their beliefs, though it may if the group violates reasonable regulations that are generally applicable.). 
ler $v . D o e^{278}$ he suggested that the vice of denying public education to the children of illegal aliens was that it "deprives a group of children of the opportunity for education afforded all other children"; ${ }^{277}$ the disfavored children were "singled out by the state and then penalized because of their parents' status."278 Similarly, in Minneapolis Star $\mathcal{E}^{\circ}$ Tribune Co. v. Minnesota Commissioner of Revenue, ${ }^{279}$ Justice O'Connor emphasized that the weakness of the tax scheme at issue was that it "singled out the press for special treatment."280

This distinction between singling out a group for treatment less favorable than that accorded most comparable groups and singling out that same group for treatment more favorable than that accorded other comparable groups might account for the outcomes in Greer v. Spock ${ }^{281}$ and the earlier dedicated public forum cases. ${ }^{282}$ In Greer the Court upheld regulations excluding political campaigning from a military training camp despite the fact that certain outside speakers were permitted to address the troops. The fact that the bulk of outside speakers were excluded, however, lent credence to the proposition that the exclusion of the plaintiffs did not reduce their communication options beyond the normal course of events. Similarly, in the public forum cases, the Court conferred special status on forums "dedicated to" particular uses. ${ }^{283} \mathrm{~A}$ "dedicated" forum can only accomplish its purposes by restricting itself to a narrow class of uses and excluding the great majority. It thus can plausibly be characterized as a bonus to the included class, rather than as a penalty to the many classes excluded.

The distinction also provides a viable rationale for Regan $v$. Taxa-

278457 U.S. 202 (1982).

272 Id. at 238 (Powell, J., concurring).

278 Id. at 239 n.3 (Powell, J., concurring).

279103 S. Ct. 1365 (1983).

280 Id. at 1370. The Court pointed out that the state had created a "special use tax, which . . . [was] without parallel in the State's tax scheme." Id. It distinguished Oklahoma Press Publishing Co. v. Walling, 327 U.S. 186 (1946), because "[t]he exempt enterprises in Oklahoma Press were isolated exceptions and not the rule. Here, everything is exempt . . . "Id. at 1371 n.5. See also Board of Educ. v. Pico, 457 U.S. 853,879 n.2 (1982) (Blackmun, J., concurring) ("I find crucial the State's decision to single out an idea for disapproval . . . ."); Thomas v. Review Bd., 450 U.S. 707, 716 (1981) (A state may not "exclude [the adherents of any particular religion], because of their faith, or lack of it, from receiving . . . benefits . . . .) (quoting Everson v. Board of Educ., 330 U.S. 1, 16 (1947) (emphasis deleted)); Tinker v. Des Moines Indep. Community School Dist., 393 U.S. 503, 510-11 (1969) (school may not "singl[e] out for prohibition . . . one particular opinion").

281424 U.S. 828 (1976).

282 See, e.g., Lehman v. City of Shaker Heights, 418 U.S. 298 (1974); Adderley v. Florida, 385 U.S. 39 (1966); Cox v. Louisiana, 379 U.S. 559 (1965).

${ }^{283}$ Lehman v. City of Shaker Heights, 418 U.S. 298, 301-03 (1974). 
tion With Representation, ${ }^{284}$ which would otherwise rest uneasily with Minneapolis Star and Speiser v. Randall. According to the Court in Regan, tax exemptions granted for lobbying by veterans organizations did not penalize nonveterans organizations because, being an anomaly, the veterans exemption did not represent the normal course of events and therefore was properly treated as a subsidy. ${ }^{285}$ In contrast, the exemptions in Speiser were generally available to veterans, and those in Minneapolis Star excused all but 16 out of 374 newspapers from paying the sales tax at issue. ${ }^{286}$

Reference to the position of most potential beneficiaries as a baseline finds support in both practice and theory. As a practical matter,

$[w]$ hen the State imposes a generally applicable [burden or denial], there is little cause for concern. We need not fear that a government will destroy a selected group . . . by burdensome [imposition] if it must impose the same burden on the rest of its constituency. When a state singles out the press, though, the political constraints that prevent a legislature from passing crippling taxes of general applicability are weakened, and the threat of burdensome [denials] becomes acute. $^{287}$

Similarly, the more anomalous the denial, the more likely it is to be perceived as a punishment for the exercise of rights and, hence, the more likely it is to deter that exercise ${ }^{288}$ and the less likely it is to be the result of an appropriately impartial weighing of costs and benefits. ${ }^{288}$ So, too, the fact that the government has been active in a number

284103 S. Ct. 1997 (1983).

$283 \mathrm{Id}$. at 2001.

${ }^{288}$ Police Dep't v. Mosley, 408 U.S. 92 (1972), and Carey v. Brown, 447 U.S. 455 (1980), present problems for analysis under the equality baseline. In each case the norm was the prohibition of speech, and favored uses were granted exceptions. Both cases, however, involved situations where the benefit in question had been historically granted (the sidewalk public forum), and where, at least arguably, there was no limited benefit that had to be parcelled out. The use of the sidewalk by the favored group did not preclude, or even raise the cost of, use of the sidewalk for the disfavored uses. Thus the defense of necessary choice was unavailable, and the baseline of history suggests a contraction of benefits.

${ }^{287}$ Minneapolis Star, 103 S. Ct. at 1372 (citation omitted). See also J. ELx, DEMOCRACY AND DISTRUST 77-82 (1980); Kalven, supra note 264, at 30; Karst, supra note 263 , at 23-25.

${ }^{283}$ This is particularly the case when the disfavored recipient is in competition with the favored. See, e.g., United States ex rel. Milwaukee Soc. Democratic Publishing Co. v. Burleson, 255 U.S. 407, 431 (1921) (Brandeis, J., dissenting) (The government may decline to subsidize the cost of distribution of all newspapers, but it may not choose to subsidize some newspapers and not others.).

${ }^{289}$ Brest, Antidiscrimination Principle, supra note 138, at 6-8; Brest, Unconstitutional Motive, supra note 138, at 95, 107-09, 120-23. 
of comparable areas undercuts the claim that it has no control over the outcome or distribution in this instance and, hence, should not be held responsible.

As all lawyers are aware, of course, any two instances can be similar or different in an almost infinite number of ways. The standard by which a court judges whether an excluded recipient is a member of a group whose members have not been excluded-whether she is "similarly situated"-presents a difficulty for the equality baseline, as for any claim of comparative justice. ${ }^{290}$ Assume that radio stations-all of which are critical of the mayor-are denied tax benefits granted to newspapers-all of which tend to be supportive. The broadcasters claim they have been excluded from benefits available to "news" media, while the mayor staunchly maintains that all "newspapers" are treated identically. In the abstract, there may be little that allows us to identify which claim accurately characterizes the denial. An examination of the concrete circumstances surrounding the denial, however, may provide more leverage on the problem. If television stations and museums also receive benefits, we are drawn to one conclusion; if they are excluded, we are drawn to another. The more striking the similarities between the excluded and included, and the smaller the class of the excluded, the more powerful the claim of the equality baseline. ${ }^{291}$ Thus, in the example of a tax benefit program affecting the media, the equality of excluding radio stations as a group might be debatable, but exclusion of a single critical newspaper would be a clear violation of the equality baseline.

Moreover, when there are discernible purposes to a benefit program, the equality of treatment accorded to individual potential beneficiaries can be evaluated with reference to these purposes. Discussion would focus explicitly on the degree to which discernible (and hence popularly approved) goals are furthered by the proposed distinction.

Resting as it does on analogical reasoning, the equality baseline

290 The fact that a claim for equality presupposes some criterion by which the similarity or dissimilarity of the cases at issue may be judged has led Professor Westen to suggest the abandonment of claims of equality as modes of legal discourse. See Westen, The Empty Idea of Equality, 95 HARv. L. REV. 537 (1982). The suggestion has not received universal acceptance. See Burton, Comment on "Empty Ideas": Logical Positivist Analyses of Equality and Rules, 91 YALE L. J. 1136 (1982); Chemerinsky, In Defense of Equality: A Reply to Professor Westen, 81 Mich. L. REv. 575 (1983); D'Amato, Comment: Is Equality a Totally Empty Idea?, 81 Mich. L. REv. 600 (1983). The dialogue continues. See Westen, The Meaning of Equality in Law, Science, Math, and Morals: A Reply, 81 Mich. L. Rev. 604 (1983); Westen, On Confusing Ideas: Reply, 91 YALE L.J. 1153 (1982). (1982).

201 Cf. G. Galabresi, A Common Law for the Age of Statutes 127-31 
can be neither exact, determinative, nor value-free. It is old news that the concept of equality presupposes a measuring rod to determine whether cases should be treated as alike or different. ${ }^{292}$ Thus, the baseline of equality calls forth the question of the relative merits of competing conceptions of desert. To some extent, the question can be answered internally, by referring to the criteria that the underlying benefit program announces as relevant.

Nonetheless, in many cases, normative controversy will be unavoidable. This, however, is one of the strengths of the approach. Rather than presuming an analogy, like the argument of the greater and the lesser, or implicitly importing a standard for evaluating government actions, like the anthropomorphic purpose model, the application of a baseline of equality calls for explicit justification of the claims that the victim is "like" the recipients who obtain the benefit. If we are willing to say that $\mathrm{Mr}$. Speiser is unlike other veterans who obtained the tax exemption, not because of his assertion of his constitutional rights, but because of other characteristics, he may lose, but we must be willing to defend the proffered distinction. Similarly, in the abortion funding cases, a crucial issue becomes what weight should be given to claims that abortions are unlike the medical treatments which receive funding.

\section{Prediction as a Baseline}

Assume that the city is about to build a superhighway, and has available two possible routes. Route 1 runs by the river. Route 2, the technically more desirable of the two, runs directly by the offices of the city newspaper most critical of the mayor; selection of Route 2 would considerably improve the paper's distribution network. The city planners have recommended Route 2. The mayor, however, sensing a chance for a political advantage, announces to the editor of the newspaper that unless the newspapers' stories on city politics become more flattering, the highway will follow Route 1 . While the proposition contemplates neither taking something the newspaper had before nor deny-

292 See Aristotle, The Politics of ARistotle 129 (E. Barker trans. 1958) (footnote omitted):

The good in the sphere of politics is justice; and justice consists in what tends to promote the common interest. General opinion makes it consist in some sort of equality. ... In other words, it holds that justice involves two factors-things, and the persons to whom things are assigned-and it considers that persons who are equal should have assigned to them equal things. But here there arises a question which must not be overlooked. Equals and unequals-yes; but equals and unequals in what? This is a question which raises difficulties, and involves us in philosophical speculation on politics. 
ing something available to members of any comparison class, it still seems to be a threat to freedom of the press. ${ }^{203}$ If it does not comply, the newspaper will be worse off than it would have been in the normal course of events.

Under this characterization the normal course of events is the course of events that would follow if the government could not impose the condition in question, or could not take the exercise of constitutional rights into account. If, without taking into account potential recipients' exercise of their constitutional rights, the government would deny the benefit, then the conditional allocation in question has increased the options available to the right-holder, and there is no constitutional violation. By contrast, if, without taking into account potential recipients' exercise of their constitutional rights, that same government would provide the benefit, the conditional allocation is not an offer that expands options, but rather is a threat that contracts the right-holder's scope of autonomy. ${ }^{294}$

In the example of the city's offer to build Route 2 on the condition that the newspaper adopt a friendlier editorial stance, the constitutionality of the condition, according to this baseline, would turn on what would have happened had the city ignored the newspaper's editorial policies. If the city still would have built the highway along Route 1, there would be no violation because the conditional allocation would provide the newspaper with an option it would not otherwise have had. However, if the city would have built along Route 2 had it not been for the newspaper's chosen speech, then the condition would decrease the options available to the paper and would, consequently, be an unconstitutional threat.

This baseline has the happy property of forcing the government to pay fair measure for the forfeiture of rights. It cannot purchase rights by granting benefits that the victim would receive anyhow. One of the

${ }^{203}$ That the mayor's intent is not the key can be demonstrated by changing the hypothetical. If Route 1 is the technically more desirable, then the mayor's proposal appears to be an offer, though the intent is identical.

$204 C$. Lyons, supra note 219 , at 436, stating that an offer by $P$ to trade his $x$ for $Q$ 's $y$ is coercive if $Q$ agrees to the exchange and " $Q$ knows that $P$ would have given $x$ to $Q$ on easier terms, if the chance had not arisen to trade $x$ for $y$." Professor Lyons suggests that the importance of this condition is that a clever tyrant would "take away people's rights wholesale, in one stunning coup, and then dribble them back retail, as conditional privileges. The tyrant could hope that people would forget that he probably would have to restore many of these privileges with or without complete compliance from the citizens, say, to prevent economic collapse." Id. at 435-36. Compare the technique of "short zoning" described in Krasnowiecki, Abolish Zoning, 31 SyRAcuse L. REV. 719, 734-49 (1980), by which a municipality zones all land at a lower use level than is ultimately desired and grants variances to developers based on criteria it could not have taken into account in its original zoning plan. 
dangers of allocative sanctions arises from the fact that, while the government must expend resources to find the victims of penal sanctions, the recipient of benefits seeks out the government. In a case in which the government would offer the benefits in the usual course of events, the additional coercive power implicit in a condition is essentially free. ${ }^{205}$ The predictive baseline eliminates this feature.

Moreover, if the benefits would be granted in the normal course of events, this supports the conclusion that the public interest favors the grant of the benefits in question and undercuts the presumption that the denial is supportable by any balancing test. In these circumstances, the government appears to be exploiting the particular need of the recipient rather than advancing a public interest. ${ }^{296}$

Admittedly, this baseline gets the courts into the risky business of predicting what the government would do, and the courts' normative vision of the public interest will inevitably intrude. Still, forcing the courts openly to focus on their conception of how the government should work is preferable to allowing them to employ the sub rosa subjectivity implicit in purpose analysis that purports to focus on a fictitious legislative intent. Furthermore, an inquiry into whether the state would have provided the benefits in question had the state not been able to take into account the exercise of constitutional rights is better grounded in concrete, observable factual premises than is an inquiry

${ }^{205}$ Cf. R. Dahl, Dilemmas of Pluralist Democracy 31-54 (1982). Professor Dahl suggests that the cost of enforcing compliance is an important safeguard against the domination of citizens by their rulers and that this "rationing of domination" accounts for the residuum of freedom in substantially totalitarian states. If domination is rendered less costly by piggybacking regulations on already committed expenditures, its scope will increase.

290 This combination of the presumptive legitimacy of what would have happened had the exercise of constitutional rights been disregarded and had the public interest been given paramount consideration was apparently persuasive in Justice Powell's concluding in Bordenkircher v. Hayes, 434 U.S. 357, 371-72 (1978) (Powell, J., dissenting), that the prosecutor's having strayed from that "normal course of events" constituted coercion. The prosecutor had decided not to charge the defendant as a habitual criminal, then threatened to do so unless the defendant pleaded quilty. Justice Powell wrote,

The deference that courts properly accord the exercise of a prosecutor's discretion perhaps would foreclose judicial criticism if the prosecutor originally had sought an indictment under [the recidivism act], as unreasonable as it would have seemed. But here the prosecutor evidently made a reasonable, responsible judgment not to subject an individual to a mandatory life sentence . ... I think it may be inferred that the prosecutor himself deemed it unreasonable and not in the public interest to put this defendant in jeopardy of a sentence of life imprisonment.

Id. at 370-71. Cf. Board of Educ. v. Pico, 457 U.S. 853, 873-75 (1982) (fact that school board removed five books, rather than the two that were recommended, taken as evidence that unconstitutional content discrimination had influenced removal decision). 
into the intent behind governmental actions. Although similar evidence may be adduced for both predictive analysis and purpose analysis, predictive analysis will focus not on illicit bureaucratic purposes, but on the nature of the program at issue-how a "rational" government should be expected to act under the circumstances-and on the importance of the contribution made by suspect conditions. It will, moreover, directly confront the claim made in support of the argument of the greater and the lesser-that the condition constitutes no expansion of governmental intrusiveness.

\section{Constitutional Triangulation}

Pleasant as it would be to have a single barometer that infallibly distinguished threats from offers, the best that I can offer at this point is three plausible ways of looking at the baseline of benefits that should characterize the normal course of events. Even this, however, is an advance over a position that simply throws courts into the problem and asks them to balance as best they can. As an initial matter, the baseline analysis gives a structure to the discussion that enables courts and litigants to differentiate among cases in terms that are subject to dialogue. More important, in the category where two or more of the baselines can be clearly drawn, we need not worry about which of the three most accurately characterizes the allocational sanction in question. And a number of interesting cases fall within this category.

We now have the conceptual apparatus to answer, for example, the puzzle of the recurring discussion of the germaneness of a condition to the purpose of the benefit program. Let us look again at the National Endowment for the Arts, a fund established for the purpose of fostering good art. Imagine that there is a consensus within the artistic and critical community that cubism is important and valuable and that pointillism is self-indulgent and insignificant. As an intuitive matter, the decision of the NEA to fund only cubist painters would appear permissible, despite the fact that by exercising their first amendment right to paint in their own style, pointillists forfeit their opportunity to receive benefits. By contrast, a failure to fund Republican painters would intuitively seem to violate first amendment norms.

In the former case, the relevance of the condition to the purpose of the benefit program is of two-fold significance. First, identifying the purpose of the benefit program makes application of the baseline of equality easier because it helps identify the intended beneficiary class. If the purpose of the NEA is to fund good art and cubism can reasonably be considered "good" art while pointillism can reasonably be considered "bad" art, then pointillists and cubists are not similarly situated 
for the purposes of the program, and a condition excluding the pointillists from receiving benefits does not violate principles of equality. Because no painters who are similarly situated to the pointillists receive benefits, the pointillists cannot claim to be penalized. The normal course of events under the NEA program is the exclusion of pointillists ("bad" painters) from the receipt of benefits. By contrast, were the NEA to deny benefits to all Republican painters, the attachment of the condition that recipients be Democrats could not be characterized as germane to the program's purpose of encouraging good art.

Second, the germaneness of cubism is a guidepost for a predictive baseline analysis. The germaneness provides some evidence of what the normal course of events would be if the government were unable to take into account the style of the painter. Choice in such a situation would be either unintelligible or random, and it is unlikely that Congress would appropriate money to support artists at random. The best prediction would be that, in the normal course of events, the pointillist would have no expectation of receiving funds.

On the other hand, in the case of a nongermane condition-that recipients be Democrats-an endowment for the arts that did not take into account political affiliation could at least arguably be expected to provide grants to artistically worthy applicants. The Republican could plausibly argue that she is worse off than she would be in the predictable or normal course of events and thus is suffering a penalty for her political affiliation.

The proposed baseline analysis also allows us to understand why, as Professor Perry put it, "the Supreme Court was plainly wrong in the Hyde Amendment case"297 and why every state court that has reanalyzed the issue under state constitutions since Harris v. McRae ${ }^{298}$ has come to agree with the dissenters in that case. ${ }^{290}$ The Hyde Amendment, ${ }^{800}$ at issue in Harris, provided that women who chose to exercise their constitutional right to terminate a pregnancy for medical reasons would be denied funding from an otherwise comprehensive

297 Perry, supra note 212.

108448 UU.S. 297 (1980).

200 See Committee to Defend Reproductive Rights v. Myers, 29 Cal. 3d 252, 625 P.2d 779, 172 Cal. Rptr. 866 (1981); Moe v. Secretary of Admin. and Fin., 382 Mass. 629, 417 N.E.2d 387 (1981); Right to Choose v. Byrne, 91 N.J. 287, 450 A.2d 925 (1982); Planned Parenthood Ass'n v. Dep't of Human Resources, 63 Or. Ct. App. 41, 663 P.2d 1247 (1983); Fischer v. Dep't of Pub. Welfare, No. 283C.D.1981 (Pa. Commw. Ct. March 9, 1984) (invalidating Pennsylvania Abortion Control Act, which barred public funding of medically necessary abortions, as violative of the state and federal constitutions), reh'g granted en banc, argued May 1, 1984.

${ }^{300}$ Act of Nov. 20, 1979, Pub. L. No. 96-123, 1979 U.S. Cone Cong. \& AD. NEwS (93 Stat.) 926. 
medical assistance program, while those who did not exercise that right would be reimbursed for the costs of childbirth.

As a matter of history, before the Hyde Amendment, abortions were funded. Thus, the elimination of funding from the medical assistance program reduced the scope of autonomy of those who sought abortions. Similarly, at least in Harris, where medically necessary abortions were at issue, ${ }^{301}$ all reproduction-related, indeed, all other medically necessary, services were funded. In terms of the purpose of the Medicaid program, abortion was no different, thus the refusal to fund abortions established a nongermane condition for the receipt of Medicaid. Analyzing the case under the equality baseline, it would be difficult to characterize the Hyde Amendment as providing a bonus for childbirth, rather than exacting a penalty for abortions.

Finally, as a matter of prediction, the best estimate of what would obtain if the government were unable to distinguish among beneficiaries on the basis of the exercise of constitutional rights is that the benefits would continue. The normal course of events is the provision of free medical care to indigents. The denial of that care to those who choose abortions gives them fewer choices because the receipt of benefits is conditioned upon failure to exercise their constitutional liberty to seek an abortion.

So, too, using the baseline analysis, one can understand how the Supreme Court could dismiss a challenge to expenditure limitations as conditions for public financing of political campaigns in a footnote in Buckley $v$. Valeo, ${ }^{\mathbf{3 0 2}}$ without mention of the cases proscribing penalties on the exercise of constitutional rights. ${ }^{303}$ Historically, public financing

so1 In Maher $v$, Roe plaintiffs sought funding for nontherapeutic abortions, while in Harris v. McRae plaintiffs challenged the exclusion of medically necessary abortions. For Justice Stevens, who had joined the majority in upholding the act in Maher, the distinction was crucial. In Harris, Justice Stevens dissented: "[I]n Maher, the plaintiffs' desire to exercise a constitutional right gave rise to neither special access nor special exclusion from the pool of benefits created by Title XIX." Id. at 350 . By contrast, in Harris a recipient's "exercise of [a constitutional right could not] provide the basis for the denial of a benefit to which she would otherwise [have been] entitled." Id. at 351.

302424 U.S. 1, 57 n.65 (1976). The footnote reads,

For the reasons discussed in Part III, . . . Congress may engage in public financing of election campaigns and may condition acceptance of public funds on an agreement by the candidate to abide by specified expenditure limitations. Just as the candidate may voluntarily limit the size of the contributions he chooses to accept, he may decide to forgo private fund-raising and accept public funding.

Earlier in the opinion, the Court struck down direct expenditure limitations as violative of the first amendment. See id. at 51.

${ }^{303}$ Professor Easterbrook takes this to be an abandonment of the unconstitutional conditions doctrine. See Easterbrook, Insider Trading, Secret Agents, Evidentiary Privileges and the Production of Information, 1981 SuP. CT. REv. 309, 348. It is not. See 
had been unavailable; the proposal to provide it on a condition increased the recipient's options to receive campaign funding. Political parties that abide by expenditure limits differ substantially from those that violate them. Because the purpose of the act in question in Buckley was to equalize the opportunities of various candidates and parties by eliminating certain disparities in the availability of funding, ${ }^{304}$ the condition that recipients abide by expenditure limitations was a germane one, and noncomplying parties could claim to be similarly situated to complying parties. Finally, in the absence of expenditure limitations, public funding would accomplish none of the purposes for which it was established because each party would simply start the competition for large contributors from a higher level of wealth. It can be predicted with relative confidence that, absent the ability to distinguish between complying and noncomplying parties, no funding at all would have been provided. Thus, the denial of funds upon violation of the condition would leave the recipients with no fewer choices than they would have had in the normal course of events.

Not all allocational sanctions, however, can be so easily analyzed. The other allocational sanction at issue in Buckley was Congress's provision of funds to only the two major parties. Members of minority parties claimed a violation of their first amendment rights, arguing that they were being denied funding because of constitutionally protected choices they made. ${ }^{305}$ This claim is less clearly resolved by the baseline analysis.

As with the conditioned expenditure limitation, the historical baseline would support the statute. However, in terms of the legitimate purposes of the statute-purposes other than the entrenchment of the existing party structure-majority and minority parties seem to be similarly situated. One could claim that the funding for the Democratic and Republican parties is really a bonus and that the statistical norm is the denial of funding to Nazis, Communists, Socialists, and other less popular parties. In terms of the values of virtual representation that support the notion of equality, however, this claim is of dubious merit given the fact that the majority of the population, if not the majority of political parties, receives the bonus. On the other hand, looking to the predictive baseline, if the government were unable to exclude minor

Widmar v. Vincent, 454 U.S. 263 (1981) (striking as unconstitutional a state university's policy of permitting only nonreligious groups to use its facilities); Thomas v. Review Bd., 450 U.S. 707 (1981) (holding unconstitutional a state unemployment board's decision denying benefits to one who quit his job fabricating military equipment because it conflicted with his religious beliefs).

sos See Buckley, 424 U.S. at 54-56.

${ }^{805}$ See id. at 33-35. 
parties, it is not improbable that the entire scheme would have been too expensive to adopt at all. In the normal course of events, as the Court suggests, ${ }^{306}$ it is not clear that, absent the program, minor parties would have been better off. The result seems to be that the discriminatory funding program passes muster under two of the three baselines.

What should a court do in such a situation? The point comes when judges must "close their eyes and choose," according to their best estimates of statesmanship and the public weal. As with many of the Buckley issues, reasonable persons will frequently differ on the outcome of a given case. Still, the courts are, under the baseline scheme, no worse off than under a scheme that calls for unstructured balancing, and they will at least have identified the relevant factors. The idea that, as in the case of discriminatory funding, "two out of three wins" is an appealing one. The case would certainly have appeared in a substantially different light if previously available subsidies to minor parties had been eliminated.

\section{B. Inalienable Rights?}

This part began with an attempt to describe the reason underlying the intuition that some allocational sanctions should be treated differently from criminal sanctions. When, by application of the three baselines, a conditional allocation can be identified as a noncoercive offer that expands rather than narrows the options of the recipient, the intuition has proved reliable. Such an offer is treated differently from the threat of criminal punishment regulating protected conduct because the offer does not reduce the scope of the right-holder's autonomy.

In such a situation, is the discussion over and the allocation constitutional? Certainly, there appear to be sound reasons for reaching that conclusion, for if a citizen believes it is to her benefit to sell her constitutional rights, why should the courts object? The answer, it turns out, varies depending on the rights at issue. The second string to Justice Holmes's argument against judicial intervention in the field of allocational sanctions serves as the starting point of my analysis.

Police officer William McAuliffe, having engaged in forbidden political discourse, threw himself on the mercy of the mayor of New Bedford with the cry "I admit I am guilty; what's the penalty?"30z Holmes

${ }^{30}$ See Buckley, 424 U.S. at 95, 99. The Court's professed inability to determine whether denial of funds to minor parties actually operated as a disadvantage, however, is less than entirely credible. See $i d$.

${ }^{807}$ McAuliffe v. Mayor of New Bedford, 155 Mass. 216, 219, 29 N.E. 517, 518 (1892). 
rejected McAuliffe's subsequent objection that removal from the police force "invaded his right to express his political opinions." Holmes opined,

[T]here is nothing in the constitution or the statute to prevent the city from attaching obedience to this rule as a condition to the office of policeman, and making it part of the good conduct required. The petitioner may have a constitutional right to talk politics, but he had no constitutional right to be a policeman. There are few employments for hire in which the servant does not agree to suspend his constitutional rights of free speech as well as of idleness by the implied terms of his contract. The servant cannot complain, as he takes the employment on the terms which are offered him. On the same principle the city may impose any reasonable condition upon holding offices within its control. ${ }^{308}$

The central phrase, concerning the absence of a right to be a policeman, has been widely quoted over the years. For two generations it formed the keystone of opinions rejecting challenges to governmental actions. ${ }^{309}$ For two more, it has been the straw man attacked by opinions sustaining constitutional rights. ${ }^{310}$ Yet, for all the recent vituperation, the announcement of the demise of Justice Holmes's principle has proved to be premature. ${ }^{311}$ Its strength comes not only from the un-

sos Id. at 220, 29 N.E. at 517-18 (emphasis added).

${ }^{209}$ See, e.g., United Pub. Workers v. Mitchell, 330 U.S. 75, 99 n.34 (1947); Zaidins v. Demet, 287 F.2d 401, 402 (7th Gir. 1961); United States v. Hoyt, 53 F.2d 881, 885 (S.D.N.Y. 1931); Gitlow v. Kiely, 44 F.2d 227, 229 (S.D.N.Y. 1930).

${ }^{10}$ See, e.g., Tygrett v. Barry, 627 F.2d 1279, 1283 (D.C. Cir. 1980) (city may not terminate a policeman in the absence of a showing that his statement impaired departmental efficiency); Alderman v. Philadelphia Housing Auth., 496 F.2d 164, 173 (3d Gir. 1974) (holding unconstitutional memorandum prohibiting city employees from discussing a public tenants' meeting); Hobbs v. Thompson, 448 F.2d 456, 473 (5th Cir. 1971) (holding unconstitutional ordinance provision restricting the electioneering activities of firemen); Kiiskila v. Nichols, 433 F.2d 745, 748 (7th Cir. 1970) (holding unconstitutional exclusion of an employee from an Army base because of her antiwar activities); Birnbaum v. Trussell, 371 F.2d 672, 677 (2d Cir. 1966) (city hospital physician entitled to notice and a hearing prior to discharge). But see Justice White's nostalgic invocation of McAuliffe v. Mayor of New Bedford, 155 Mass. 216, 29 N.E. 517 (1892), as the beginning point of the "historical evolvement [sic] of the rights of public employees," in Connick v. Myers, 103 S. Ct. 1684, 1688 (1983).

${ }^{311}$ Compare Van Alstyne, Right-Privilege Distinction, supra note 43, (arguing that the concept of "privilege" is no longer alive) and Van Alstyne, Public Employees, supra note 43 (same) with Appleton, supra note 98 (suggesting that the redefinition of the "right" to an abortion in the abortion funding cases as a negative right may auger a dilution of all individual constitutional rights). Compare Note, Civil Disabilities and the First Amendment, 78 YaLE L.J. 842, 861 (1969) (predicting that the Hatch Act, which limits the political activities of government employees, would be found unconstitutional as an impermissible burden on rights of association) with Broadrick v. 
doubted elegance of presentation, but from its appeal to common experience. And it is this appeal that must be met head on by those who invoke the notion "inalienable rights" to prevent the government from "buy[ing] up "rights guaranteed by the Constitution." "312

\section{The Appeal of Analogy}

Part of Holmes's exposition relies on the analogy between private and public employment. In accepting any private employment, indeed in executing any contract, a citizen sells rights. In Holmes's conception, the contracting party agrees to be subject to sanctions for the exercise of a right that would otherwise be immune from state interference. Those sanctions are usually in the form of damages, but Holmes in other contexts saw nothing untoward in attaching criminal penalties to the breach of an employment contract. ${ }^{313}$ Whatever the Declaration of Independence may say, such rights clearly are, quite literally, alienable. Thus, Holmes's rhetorical question: If a private party can induce the surrender of constitutional rights with monetary incentives, what is the objection to the government engaging in similar practices? Indeed, the implicit argument by analogy goes one step further: If government must have employees to operate and employment by definition involves the surrender of freedom, is not the allegedly unconstitutional transaction inherent in any government that can enforce its decrees?

In its pure form the analogy applies only to employment relations. There is nothing particularly self-contradictory about constraining the government from requiring the waiver of constitutional rights as condition for receipt of welfare benefits, driver's licenses, or opera tickets. The government can accomplish its goals in each area perfectly well without the conditions. As a matter of analogy, outside of the area of employment, Holmes's position depends on parallels between the government and private property holders in general. But the analogy is faulty. The considerations supporting the right of a property owner freely to dispose of her property are generally inapplicable to

Oklahoma, 413 U.S. 601 (1973) (upholding Oklahoma's version of the Hatch Act) and United States Civil Serv. Comm'n v. National Ass'n of Letter Carriers, 413 U.S. 548 (1973) (upholding the Hatch Act).

312 Wyman v. James, 400 U.S. 309, 328 (1971) (Douglas, J., dissenting). See Frost \& Frost Trucking Co. v. Railroad Comm'n, 271 U.S. 583, 593-94 (1926); Townsend v. Townsend, 7 Tenn. (Peck) 1, 12 (1821).

sis See Bailey v. Alabama, 211 U.S. 452 (1908) (Holmes, J., dissenting); $c f$. Snepp v. United States, 444 U.S. 507 (1980) (granting damages to the government upon an employee's breach of an agreement not to divulge information without clearance from the GIA). 


\section{government. $^{314}$}

Even in the central case of employees, moreover, Holmes's conclusions are suspect. Whatever the situation in Holmes's time, it is far from clear that most private employers today can penalize the exercise of constitutional rights. ${ }^{316}$ The emerging doctrines of retaliatory discharge $^{\mathbf{3 1 6}}$ and the existing constraints in federal law ${ }^{\mathbf{3 1 7}}$ limit such behavior in the private sector. More importantly, under the impact or threat of unionization, the prerogative of arbitrary or invidious discharge has evaporated from major portions of the private sector, without substantially impairing the ability of enterprises to function. ${ }^{318}$ To the extent that the government attempts to impede unionization of pub-

s14 See supra text accompanying notes 67-97.

s15 See M. Glendon, The New Family and the New Property 151-70 (1981).

sic See, e.g., Tameny v. Atlantic Richfield Co., 27 Cal. 3d 167, 610 P.2d 1330, 164 Cal. Rptr. 839 (1980) (discharge of an employee for refusal to participate in an illegal pricefixing scheme constitutes a cause of action for wrongful discharge); Palmateer v. International Harvester Co., 85 Ill. 2d 124, 421 N.E.2d 876 (1981) (cause of action exists for wrongful discharge of employee for supplying information about fellow employees to a law enforcement agency); Fortune v. National Cash Register Co., 373 Mass. 96, 364 N.E.2d 1251 (1977) (employer may not discharge an employee to avoid paying bonuses to him); Monge v. Beebe Rubber Co., 114 N.H. 130, 316 A.2d 549 (1974) (termination of contract of at-will employee activated by bad faith, malice, or retaliation constitutes breach of the contract); Lally v. Copygraphics, 85 N.J. 668, 428 A.2d 1317 (1981) (recognizing cause of action for a discharge attributable to the filing of a worker's compensation claim by employee); Reuther v. Fowler \& Williams, Inc., 255 Pa. Super. 28, 386 A.2d 119 (1978); see also Blades, Employment at Will vs. Individual Freedom: On Limiting the Abusive Exercise of Employer Power, 67 Couum. L. REv. 1404 (1967); Murg \& Scharman, Employment at Will: Do the Exceptions Overwhelm the Rule?, 23 B.G.L. REv. 329 (1982); Summers, Individual Protection Against Unjust Dismissal: Time for a Statute, 62 VA. L. REv. 481 (1976); Note, Protecting At Will Employees Against Wrongful Discharge: The Duty to Terminate Only in Good Faith, 93 HARv. L. REv. 1816 (1980).

${ }^{317}$ See, e.g., Bomar v. Keyes, 162 F.2d 136 (2d Cir.) (allowing damage action under Civil Rights Act for discharge of employee who was absent from work because of jury duty), cert. denied, 332 U.S. 825 (1947).

42 U.S.C. $\S 1985$ (1976) and federal whistleblowing statutes have also proved to be significant protectors of constitutional rights in the employment context. See, e.g., Richardson v. Miller, 446 F.2d 1247 (3d Cir. 1971) (employment suit under § 1985); Britt v. Suckle, 453 F. Supp. 987 (E.D. Tex. 1978) (same); Larvadain v. Rapides Parish School Bd., 348 F. Supp. 24 (W.D. La. 1972) (same); see also 42 U.S.C. § $2000 \mathrm{e}-3$ (a) (1976) (prohibiting retaliation or discharge for employee's support of other employee's civil rights); 42 U.S.C. \& 5851(a)(3) (Supp. IV 1980) (providing that no employer shall discharge or otherwise discriminate against an employee who has "assisted or participated, or is about to assist or participate in any manner in . . . a proceeding under the [Energy Reorganization Act of 1974] or, in any other action to carry out the purposes of [the Act] . . . .”); 42 U.S.C. $\$ 7622$ (a) (Supp. IV 1980) (providing that an employer may not discharge or otherwise discriminate against any employee because the employee commenced, caused to commence, or testified at a proceeding against the employer for violation of the Air Pollution Prevention and Control Act).

${ }^{818}$ Ninety percent of collective bargaining agreements limit the employer's right of arbitrary discharge. Note, supra note 316, at 1832. 
lic employees yet desires to retain an alleged immunity from constitutional constraints, ${ }^{319}$ it seeks to enjoy the benefits of public status while avoiding the burdens.

The example of private unionization suggests that the disregard for most constitutional rights is far from essential to the proper functioning of government. The real question raised is not analogical, but substantive: How much does recognition of the constitutional claim impair other legitimate public goals? Analogy yields no support for the suggestion that the significance of this answer should differ depending on whether the sanctions for assertion of constitutional rights are criminal or allocative. ${ }^{320}$ In itself, the employment relation neither compels nor forbids the conclusion that offers to purchase constitutional rights are acceptable.

\section{The Problem of Waiver}

Not only is there nothing untoward about an employer attempting to control otherwise constitutionally protected aspects of the employee's life, says Holmes, but "[t]he servant cannot complain"321 since he has agreed to the exercise of that control. In accepting the benefit, the beneficiary has freely accepted the condition and cannot now be heard to disavow his bargain: "[H]e takes the employment on the terms which are offered him." ${ }^{\text {322 }}$ It is true, of course, that a bargain might be voided for fraud or duress, but here we have neither. The condition was clearly attached to the employment, and the employee was not forced to

s19 See supra text accompanying notes 67-97.

s20 The mischief of a misused analogy is illustrated by Justice White's opinion in Connick v. Myers, 103 S. Ct. 1684 (1983), which approved the dismissal of an assistant district attorney for circulating a questionnaire without "any evidence . . . that the plaintiff's work performance was adversely affected,' " $i d$. at 1700-01 (Brennan, J., dissenting) (quoting Myers v. Connick, 507 F. Supp. 752, 759 (E.D. La. 1981)) and where, according to the factual determinations of the district court, the petition "had no adverse effect on [the plaintiff's] relationship with her superiors." Id. at 1700-01.

The thrust of the opinion is the "common sense realization that government offices could not function if every employment decision became a constitutional matter," $i d$. at 1688 , and that the first amendment "does not require a grant of immunity for employee grievances not afforded by the First Amendment to those who do not work for the state," $i d$. at 1690 . Unfortunately, common sense and fact tend to diverge since it seems unlikely that Myers's behavior would have warranted dismissal in a unionized setting or, in any event, substantially threatened any employment interest.

The Court's suggestion that only comments on matters of public policy are protected, id. at $1688-90$, seems patently misguided since even Justice White would presumably hold statements regarding the morality of atheism, for example, to be protected.

${ }^{321}$ McAuliffe v. Mayor of New Bedford, 155 Mass. 216, 220, 29 N.E. 517, 518 (1892).

322 Id. 
accept.

This essay is not the place for a full analysis of the role of waiver in constitutional rights, an area in which substantial ink has been spilled $^{\mathbf{3 2 3}}$ and in which substantial thought remains to be expended. Nonetheless, whatever the precise prerequisites for a valid waiver of constitutional rights, ${ }^{\mathbf{3 2 4}}$ some fact patterns clearly preclude the use of the waiver argument to justify disparities between criminal and allocative sanctions.

We begin with the appeal of the arguments for waivers: they appear to respect individual choices. If the constitutional right in question is designed to secure an area of autonomy for the citizen against the state, it would seem that the exercise or nonexercise within that area should be in the hands of the citizen. If she wishes to waive her rights, to refuse her that option appears to limit rather than extend her choice. ${ }^{325}$ Likewise, if a right is intended to secure the welfare of a citizen, it requires a paternalism that is on its face incompatible with a vision of constitutional rights as protecting individual choice to warrant limiting the citizen's ability to waive the right should she believe that it would leave her better off to do so. ${ }^{328}$

A doctrine respecting individual choices, however, requires that such choices should at least result from conscious choice. Thus, in situ-

323 See, e.g., Calabresi \& Melamed, Property Rules, Liability Rules, and Inalienability: One View of the Cathedral, 85 HARv. L. Rev. 1089 (1972); Dix, Waiver in Criminal Procedure: A Brief for More Careful Analysis, 55 TEx. L. REv. 193 (1977); Spritzer, Criminal Waiver, Procedural Default and the Burger Court, 126 U. PA. L. REv. 473 (1978); Tigar, The Supreme Court, 1969 Term-Foreword: Waiver of Constitutional Rights: Disquiet in the Citadel, 84 HARv. L. REv. 1, 24-27 (1970); Westen, Away from Waiver: A Rationale for the Forfeiture of Constitutional Rights in Criminal Procedure, 75 Mich. L. REv. 1214 (1977). Recently, Professor Rubin engaged in an ambitious attempt to integrate the law of constitutional waiver and waiver in the contracts and torts contexts. See Rubin, Toward a General Theory of Waiver, 28 UCLA L. REv. 478 (1981).

234 Compare Overmyer Co. v. Frick Co., 405 U.S. 174, 185-86 (1972) (relaxed waiver standard applicable to confession of judgment by corporation; at least where waiver of right to notice and a hearing was voluntary, knowing, and intelligently made, it will be considered a valid waiver) with Johnson v. Zerbst, 304 U.S. 458, 465 (1938) (an intentional relinquishment of a known right or privilege of the right of a criminal defendant to be represented by counsel must be intelligent and competent to be valid).

${ }^{325}$ Goodin, The Political Theories of Choice and Dignity, 18 AM. PHIL. Q. 91, 92, 94 n.19 (1981).

${ }^{326}$ See Calabresi \& Melamed, supra note 323, at 1113-14. There is also an argument, in some situations, that a waiver should be enforceable because of the reliance of the government; the citizen should not be able to retain both the advantages of assertion and nonassertion. See, e.g., Simons, Rescinding a Waiver of a Constitutional Right, 68 GEO. L.J. 919 (1980); Westen, supra note 323. Whatever the merits of predicating a constitutional doctrine on the necessity of protecting the government from exploitation by its citizens in a criminal context, it seems that it should be limited to, at most, the facts that give rise to it. 
ations where no real choice exists vis-à-vis the proffered incentive, one cannot claim comfort from discussion of waiver. In Fleming v. Nestor, ${ }^{\mathbf{3 2 7}}$ for example, the disqualification from Social Security benefits at issue was imposed years after the plaintiff had become a member of the Communist Party. It is difficult to characterize the plaintiff as declining an offer to sell his constitutional rights, for the condition in question was imposed after he had violated it. Even had the plaintiff been fully informed of the contemporary consequences of his actions at the time he joined the party, he could not have known of a consequence that was yet to be imposed.

Where all the consequences of an action are identifiable when the recipient acts, there is a strong tradition that she must be told of them before her waiver of constitutional rights is deemed knowing. ${ }^{328} \mathrm{Al}$ though in particular situations efficiency requires the imputation of knowledge, the normative power of the waiver doctrine lies in its attempts to recognize the conscious exercise of individual autonomy. Thus, courts relying on waiver to justify a lower level of constitutional scrutiny should be attentive to whether an actual exercise of conscious individual choice is present.

Such attention was distinctly absent in United States Postal Service v. Council of Greenburgh Civic Associations, ${ }^{329}$ where Justice Rehnquist justified a ban on placing unstamped matter in home postal boxes on what appeared to be grounds of waiver. Although recognizing that postal customers might have a right to receive unstamped mail Rehnquist argued,

Anyone is free to live in any part of the country without having letters or packages delivered or received by the Postal Service by simply failing to provide the receptacle. ... What the legislation and regulations do require is that those persons who do wish to receive and deposit their mail at their home or business do so under the direction and control of the Postal Service. ${ }^{330}$

Leaving aside the question of whether the government could, on this theory, also criminalize Federal Express deliveries to postal patrons, many postal customers would no doubt be surprised to learn that they "[agree] to abide by the Postal Service's regulations in exchange for the 
Postal Service agreeing to deliver and pick up [their] mail."331 They would have thought they were simply being provided a public service, and certainly they had no knowledge of the rights that they were waiving in accepting it. Such a contrived waiver hardly provides substantial support for relaxing protection of constitutional rights. ${ }^{332}$

Nonetheless, there are events where it appears that a real choice is made, events resembling the classical sale of a widget. Assuming that a valid choice is present, the argument that such a choice constitutes an effective waiver presupposes that the constitutional right violated is in fact waivable in the circumstances at issue. ${ }^{333}$ Three elements are logi-

ssi $I d$. at 128.

s32 Cf. Connick v. Myers, 103 S. Ct. 1684 (1983), in which Myers violated no existing job norm. Compare McAuliffe v. Mayor of New Bedford, 155 Mass. 216, 29 N.E. 517 (1892), in which McAuliffe at least knew he would be fired.

sss I specifically exclude from this discussion the issue of the voluntary nature of the waiver. At one level, the requirement of a "voluntary" waiver blends into the problem of the definition of the appropriate baseline. If the argument in favor of waivers is that recognition of the waiver is thought to expand the scope of individual options, then response to an offer that in fact contracts those options should not be recognized as a waiver. If the argument in favor of recognition of the waiver is that such recognition vindicates the will of the individual whose rights are to be protected, then this is an additional argument in favor of considering offers as previously defined to be voluntary. Presumably, the subject of the offer would choose to have the offer made since it makes her better off than she would be in the normal course of events. On the other hand the sacrifice of a right in response to a threat would be considered involuntary because, given the choice, the subject would prefer the normal course of events. Making the threat fails to recognize the subject's will. See Nozick, supra note 220. However, if it does not duplicate the baseline problem above, the concept of voluntariness seems to me extremely problematic. See generally Dix, supra note 323; Rubin, supra note 323.

I do not mean to say that the issue of voluntariness has been absent from discussions of waiver. On the contrary, discussions of voluntariness have been omnipresent and overused. See, e.g., South Dakota v. Neville, 103 S. Ct. 916, 923 (1983) (stating that when the state offers one a choice between taking a blood alcohol test or having her refusal to take the test used against her, the state presents a "true choice," rather than a coerced one); Steward Machine Co. v. Davis, 301 U.S. 548, 589-91 (1937) (stating that the states are not coerced by the tax imposed by Title IX of the Social Security Act of 1935, but rather are provided with a "motive" to participate in the cooperative plan). Indeed, even Justice Holmes on occasion utilized the concept as an escape when he found a governmental action too intrusive. See Union Pac. R.R. v. Public Serv. Comm'n, 248 U.S. 67, 69-70 (1918) (Holmes, J., for the Court) (stating that the Court must be certain that a right has been voluntarily waived before it considers the waiver valid, in order to prevent the imposition of "an unconstitutional burden by the threat of penalties worse than it in case of a failure to accept it").

Two recent commentators apparently seek to limit the use of waivers with an inchoate requirement of equality of bargaining power or a refusal to allow government conditions where the government holds a monopoly of the services conditioned. See Smolla, The Reemergence of the Right-Privilege Distinction in Constitutional Law: The Price of Protesting Too Much, 35 STAN. L. REv. 69, 116 (1982); Terrell, "Property," "Due Process," and the Distinction Between Definition and Theory in Legal Analysis, 70 GEO. L.J. 861, 901-03 (1982). The questionable clarity of commercial law's analysis of "disparities in bargaining power" does not seem to recommend its transfer to the constitutional context. 
cally necessary to validate such a presupposition.

First, the right in question must be waivable; the victim must be able to choose not to exercise the right. The peonage cases, ${ }^{334}$ for example, establish that thirteenth amendment rights cannot be waived. Slavery is forbidden whether or not a person "consented" to it.

Second, the right in question must be alienable; the power not to exercise the right must be transferable to another party in exchange for the proferred benefit. ${ }^{\mathbf{3} 5}$ That the two elements are not identical is illustrated by the status of voting: a citizen may either vote or not vote, but it is illegal to sell the exercise of the right.9si

Third, it must be permissible for the state to attempt to obtain such a waiver or transfer. Uncle Felix may make his bequest conditional on the beneficiary attending church. Uncle Sam may not.

At first glance, a belief that constitutional rights serve to protect the freedom of the citizen implies that the citizen should be entitled to dispose of that freedom as she chooses. On the other hand, the concept of inalienable rights is scarcely foreign to constitutional thinking, ${ }^{337}$ and a distaste for those who trade their birthrights for messes of pottage has a still longer genealogy. Repetition and age, of course, do not guarantee the truth of the maxim, but there are constitutional rights that we do regard as inalienable.

To identify each of these rights and the degree to which the government is constrained from purchasing the waiver of each is beyond the scope of this paper. Rather, what follows is an attempt to identify the kinds of arguments that, in any particular case, can support a claim of the impropriety of government purchases. The success of an argument in a given case will turn on the appropriate relation between citizen and government, the nature of the rights at issue, and the fundamental nature of an acceptable society. My goal at this stage is not to

ss4 See, e.g., Bailey v. Alabama, 219 U.S. 219 (1911); Clyatt v. United States, 197 U.S. 207 (1905); see also the excellent discussion of the peonage cases in Schmidt, Principle and Prejudice: The Supreme Court and Race in the Progressive Era. Part 2: The Peonage Cases, 82 Colum. L. REv. 646 (1982).

385 This understanding of the meaning of alienability is in accord with the useage of "unalienable" in the Declaration of Independence. See J. FeINBERG, Voluntary" Euthenasia and the Inalienable Right to Life, in RIGHTS, JUSTICE, AND THE BoundS of Liberty 240-41 (1980); M. White, The Philosophy of the AMERICAN Revolution 196 (1978); Richards, Inalienable Rights: Recent Criticism and Old Doctrine, 29 Phil. \& Phenomenological Research 391, 398 (1969).

${ }^{338} 42$ U.S.C. $\S 1973 \mathrm{i}(\mathrm{c})$ (1976) (making it illegal to pay or to offer to pay or accept payment for registering to vote or for voting).

s37 See The Declaration of Independence (U.S. 1776); Home Ins. Co. v. Morse, 87 U.S. (20 Wall.) 445, 451 (1874) ("A man may not barter away his life or his freedom, or his substantial rights."); Townsend v. Townsend, 7 Tenn. (Peck) 1, 12 (1821) ("Constitutional rights are vested, unexchangeable, and unalienable."). 
decide cases, but to structure inquiry.

\section{a. Waivable and Non-waivable Rights}

The case for recognition of waivers rests on the conviction that constitutional rights protect individual choice. But many constitutional rights protect other values or protect individual choice only as a means to the realization of other ends. For such rights, there is no paradox in asserting that the choice of the individual should not decide the applicability of the right in question. Thus, in Insurance Corp. of Ireland $v$. Companie des Bauxites de Guinee, ${ }^{338}$ Justice White distinguished between article III limitations on jurisdiction, which cannot be established by estoppel or action of the parties, and the personal jurisdiction requirement that "recognizes and protects an individual liberty interest" and can be waived. . $^{399}$ The latter "represents a restriction on judicial power not as a matter of sovereignty, but as a matter of individual liberty. ... . [The fact that] the requirement of personal jurisdiction may be intentionally waived ... portray[s] it for what it is-a legal right protecting the individual." "s40 To the extent that a right is the result of a definition of the structure and power of government, an individual decision to waive it is irrelevant.

Similarly, it may be that the right defines not the structure of government, but the structure of a decent society. A decent society does not tolerate cruel and unusual punishment. If a state were to grant inmates a choice between tolerable prison conditions and a five-year shorter term in an unreconstructed Arkansas prison farm, ${ }^{341}$ it seems unlikely that a court would sustain the program, however beneficial the inmates thought it. ${ }^{\mathbf{4 2}}$ So too, one of the messages of the Reconstruction Era was that a decent American society does not allow slavery. The burden of the thirteenth amendment was not only the protection of individual liberty, but the eradication of a social practice deemed incompatible with a

388456 U.S. 694 (1982).

sso Id. at 702 .

s6o Id. at 702, 704.

341 See Hutto v. Finney, 437 U.S. 678 (1978) (upholding district court order that confinement in punitive isolation in an Arkansas prison be limited to 30 days maximum because of conditions so deplorable as to violate the eighth amendment).

312 When I initially constructed this example, I thought it moderately farfetched. As it turns out, my imagination was less fertile than that of the South Carolina judiciary. See Castration or Incarceration?, TimE, Dec. 12, 1983, at 70 (reporting sentencing of three defendants in a rape case to either 30 years imprisonment or castration); Rapists Having Second Thoughts on Choosing Castration, N.Y. Times, Dec. 11, 1983, § 1 at 35, col. 1; see also Scott v. Hayes, 719 F.2d 1502 (11th Gir. 1983) (challenge to state judge's conditioning award of property in divorce proceeding on husband's obtaining vasectomy): 
free society. If one believes that a purpose of the fourteenth amendment was to eliminate the caste system that had grown up around slavery, a plausible belief, the assent of any given member of the "underclass" would not waive her equal protection rights. ${ }^{343}$ And the right to education, resurrected in Plyler $v$. Doe, might well not be subject to waiver by its beneficiaries. ${ }^{344}$

Thirteenth and fourteenth amendment rights, as well as the education right, raise yet another reason why a right might not be deemed waivable: paternalism. For education, the argument is easy. Children may not know what is in their own best interest, and the relative competence of parents and the state is problematic. ${ }^{345}$ For fourteenth amendment rights, one might argue that victims of a caste system would be so beset by false consciousness that their choices would be unreliable. The latter argument, however, lies uneasily with most of the presuppositions of the rest of the American legal system and not least the underpinnings of many constitutional rights. ${ }^{346}$ The "false consciousness theory," therefore, seems an unlikely candidate for precluding waiver of constitutional rights. ${ }^{347}$

s43 Compare the strand of Lockean thought current at the time of the American Revolution that held that certain rights were granted by God and that, therefore, any attempt by a person to alienate them would be invalid and J. FeINBERG, supra note 335, at 241-42 (describing Samuel Adams's views) and A. MELDEN, RigHTS AND Persons 178-79 (1977) (describing the influence of Locke's natural rights theory on the authors of the Declaration of Independence) and R. TUCK, NATURAL RIGHTS ThEORIES 173 (1979) (describing Locke's views) and M. WHITE, supra note 335, at 205-13 (describing the views of Jefferson and Locke) with the alternative interpretation of Locke that held that the inalienability of rights flowed from a duty not to attempt to interfere with others' rights or to allow others to act in a way inconsistent with their rights and $\mathrm{R}$. Tuck, supra, at 172-73 and M. WHITE, supra note 335 , at 201 (interpreting Jefferson as having argued that the freedom of belief rested on a duty imposed by God "to desist from trying to alter the fact that human opinions are necessarily brought about by what is taken to be evidence").

s44 If the basis of the holding in Plyler is a constitutional aversion to the establishment of a permanent "underclass," 457 U.S. at 219 , reminiscent of the caste system imposed by slavery, the willingness of a particular child to decline education may be irrelevant.

345 Cf. Wisconsin v. Yoder, 406 U.S. 205 (1972) (resting the decision that Amish children cannot be required to attend school beyond a certain age on the religious beliefs and desires of their parents rather than themselves). Compare id. at 241 (Douglas, J., dissenting) (arguing that the children's rights should be more fully recognized).

s16 There seems to be substantial support from both sides of the aisle for the view that the attempt to choose for another what that person "really wants" in the name of freedom has a tendency to degenerate into totalitarianism. Compare I. BERLIN, Two Concepts of Liberty, in Four Essays on LIBERTy 133-34 (1969) with C. MACPherson, Berlin's Division of Liberty, in Democratic TheORY: EsSays IN RETRIEval 111-17 (1973).

347 But see the arguments in favor of safety regulation that are based on the public's inability to evaluate and process low level risk information in G. CALABRESI, THE Cost of Accidents: A Legal and Economic Analysis (1970); R. Goodin, Po- 
Finally, with respect to thirteenth amendment rights, one might argue for what Professors Calabresi and Melamed have termed "selfpaternalism." "s48 If selling oneself into slavery is the type of transaction that is usually regretted, however tempting it seems at the time, a rational citizen might well wish that she not have the power to enter into such a transaction..$^{349}$

\section{b. Alienable and Inalienable Rights}

Even when a right is waivable, there may be aspects of the alienation of the right that would overcome any presumption of legitimacy arising from a desire to vindicate individual choice. First, the transfer of the right from one party to another might have undesirable ramifications for other members of society. Assume a three-person society governed by a majority vote. Arafat owns W, and Meir wants W, while Hussein is indifferent about ownership of $W$. If votes are inalienable, in order to obtain W, Meir must either obtain Arafat's consent and compensate him for his loss or else convince Hussein that she is entitled to $W$. However, if votes are alienable, as long as Meir can outbid Arafat for Hussein's vote, she can obtain W without consent, compensation, or persuasion. ${ }^{350}$ Moreover, there may be something unseemly,

litical Theory and Public Policy 49-50 (1982).

368 Calabresi \& Melamed, supra note 323, at 1113-14.

sco Id.; see also R. Goodiv, supra note 347, at 37-49. This may also be an explanation for the holding in NLRB v. Magnovox Co., 415 U.S. 322 (1974), that the union cannot waive the free speech rights of its members under the NLRA. The union's political composition may change sufficiently from the time of the waiver that it seems inappropriate to bind members who join after the waiver or members whose opinions change.

Our refusal to allow the alienation of rights by others because of our belief that they would wish to protect themselves from the temptation to alienate those rights may arise from less admirable motives, however. As Professors Calabresi and Bobbitt point out, society's desire to prohibit peonage might arise as much from its discomfort at witnessing " $t]$ he willingness of a poor man, confronting a tragic situation, to choose money rather than the tragically scarce resource, [a choice that] always represents an unquiet indictment of society's distribution of wealth," G. CALABRESI \& P. BOBBITT, TrAgic Chorces 33 (1978), as from its wish to facilitate the realization of an individual's desire to prevent herself from being confronted with such a tempting, but unwise, choice.

${ }^{350}$ Meir will bargain for Hussein's vote rather than directly for Arafat's W because, by drawing Arafat into the bidding for $W$, she can be sure that the bidding will stop when it reaches a price equal to Arafat's real valuation of $W$. Meir thus avoids paying more for the vote than she would have had to pay to buy $W$ from Arafat. If imperfections enter the picture, such as disparities in wealth, wealth effects and imperfect capital markets, or organization costs for the Arafat tribe, $c f . M$. Olson, The logic of Collective Action: Public Good, and the Theory of Groups (1971), Meir may get $W$ for much less than Arafat would ask.

A similar analysis might apply to Arafat's sale at T1 of his right to engage in political debate to attempt to influence Hussein in the future. $C f$. NLRB v. Magnavox 
disquieting, or destructive about the process. Once the precedent of bidding is established, future attempts at persuasion are less likely to proceed on a plane of disinterested reason, and a market in babies, blood, or bodies may reduce respect for closely-held values. ${ }^{\mathbf{3 5 1}}$

Even where there are no effects on third parties, it may be that we have constitutional preferences regarding the distribution of the right in question. If our conception of democracy requires that voting power be distributed equally, ${ }^{\mathbf{3 6 2}}$ or if our view of justice requires that punishment be imposed according to guilt, the opportunity to exchange the power to vote or the freedom from punishment for government favors will result in deviation from those norms. The rights will then be distributed according to which right-holders have particular need of the government favors in question. This will violate the appropriate distribution of the right. ${ }^{\text {s53 }}$ More, it may be a particularly obvious double-disadvantaging of the already disadvantaged, for a member's chance of political success is related to the political strength of other members of her interest group. ${ }^{354}$

Co., 415 U.S. 322 (1974) (union cannot waive the free speech of its members).

ssi See R. Trtmuss, The Gift Relationship: From Human Blood to Social Policy 158 (1971). But see Arrow, Gifts and Exchanges, 1 Phil. \& Pub. Aff. 343 (1972).

Indeed, one of the "externalities" that may result from the sale of votes or political power is the demise of the market system itself, for an effective market presupposes the definition of property rights by some means external to the market. See Arrow, supra, at $351,357$.

s52 See J. Rawls, A Theory of Justice (1972). Of course, Rawls's point that an equal distribution of liberties fosters a sense of social solidarity cuts both ways in this context. It could be argued either that making political liberties inalienable would foster a sense of self-respect among even the least well-off or that the inalienability assures an apparently equal distribution of rights that distracts attention from the truly important disparities in power outside the symbolic sphere.

Alternatively, it may be that we accept the outcome of market transactions despite the unequal distribution of wealth precisely because the equal distribution of voting power provides a check on unacceptable outcomes resulting from market exchanges. See Rose-Ackerman, A New Political Economy?, 80 Mrch. L. Rev. 872, 879 (1982); RoseAckerman, Inalienability and the Theory of Property Rights, Working Paper No. 3, Center for Law and Econ. Studies, Columbia Law School 36-37 (Oct. 1983).

sts See M. Walzer, Spheres of Justrce: A Defense of Pluralism and EQUality 19 (1983) (defining tyranny as the distribution of goods according to inappropriate criteria).

354 The point here is a combination of the free rider and prisoner's dilemma problems. If an economically and socially disadvantaged group is to improve its collective lot, political action is necessary since, by definition, the group lacks economic and social resources. The government deals primarily in public or quasi-public goods-sewers, antidiscrimination legislation, and the like. It is advantageous for any given member of the least well-off group, if votes are alienable, to sell her vote rather than use it to attempt to obtain a public good for her group. If others sell their votes, she is no worse off for having sold her vote, and if other members of her group retain their votes and vote for the public good, she will obtain the good in any event. On the other hand, if she retains her vote and her compatriots do not, she will have gained 


\section{c. The Propriety of Government Requests for Waiver}

Rights that may be alienated to private parties may still be unavailable for sale to the government. If the right in question exists because the government is constitutionally prohibited from placing a value on exercise of that right, then it would be similarly inhibited from seeking a waiver. The establishment and free exercise clauses prohibit government from favoring one religion over another. Thus, even if a parolee were to agree to a parole conditioned on regular church attendance, the condition would be ineffective, for the government would be barred from seeking such a waiver. ${ }^{355}$

A similar result obtains if the government is prohibited from attempting to affect exercise of the right in question because of effects on the structure of the society. If Justice Brennan is right in Zobel that the right to travel is not a personal one, but an element of the national union, ${ }^{356}$ then one explanation for the Zobel opinion is that the right in question could not be waived by newcomers since it was not theirs to waive.

Most importantly, the government may be barred from attempting to obtain waivers of constitutional rights because such attempts may constitute an unacceptable accumulation of power over the right in question. ${ }^{357}$ If federalism dictates that certain decisions be withheld from the federal government and entrusted to the states, a state waiver

nothing, and she knows that her compatriots, faced with the same choices, will probably "rationally" choose to sell.

It is apparently a variant of this concern that causes Professors Easterbrook and Fischel, in Voting in Corporate Law, 26 J. L. \& EcoN. 395, 411 (1983), to support the traditional restraints on alienability of votes in the corporate contest. They state,

Because no voter expects to influence the outcome of the election, he would sell the vote (which to him is unimportant) for less than the expected dilution of his equity interest. He would reason that if he did not sell, others would; he would lose on the equity side but get nothing for the vote. Thus any non-zero price would persuade him to sell.

sss This seemed obvious to courts even in the heyday of the right-privilege distinction. See, e.g., Jones v. Commonwealth, 185 Va. 335, 38 S.E.2d 444 (1946) (state may not grant probation contingent on defendant's attending Sunday school and church).

ss6 457 U.S. at 55.

ssz With respect to the government, one of the standard justifications for the free transferability of rights is inapplicable. Although it may be argued that in a private market, free transferability ensures that property rights will migrate to their most productive use, this result hinges on the suggestion that the offering price offered by a buyer represents the economic value of the right to the buyer. Given that the government accumulates resources for the most part not by production, but by taxation, the amount that the government is willing to offer does not reflect anything about the economic value of the right in question. Since it is precisely the desire to shield individual liberties from the will of the majority that justifies the establishment of constitutional rights in the first place, it is hardly a persuasive argument that the majority very much wants to have its rights remain unexercised. 
should be irrelevant. In a like manner, if the government is to be responsive to the outcome of public debate, it is hardly entitled to manipulate the discussion. The fact that those manipulated may consent to the manipulation makes the government's actions no less than an attempt to fix the prices in the marketplace of ideas.

All of this, again, turns on the precise roles played by the right in question in the political and constitutional scheme and on a practical evaluation of the impact of allowing sales to the government. Consider, for example, the differing treatment accorded the requirements of party loyalty and political neutrality as conditions for government employment. The requirements of the Hatch Act ${ }^{358}$ have been repeatedly upheld, ${ }^{350}$ while patronage requirements have been disapproved. ${ }^{\mathbf{3 6 0}}$

From the perspective of individual autonomy, there seems to be little difference between the two situations. Justice Powell may have a substantial argument in his suggestion that patronage employees have waived their right to object to further patronage activities. ${ }^{\mathbf{5 6 1}}$ However, given the opportunities for an expanding public sector to lock in political support for a self-perpetuating hierarchy, requiring party affiliation as a condition of public employment is incompatible with the checking values of the first amendment. ${ }^{362}$ Moreover, patronage cannot function without the government taking a position on the orthodoxy of political affiliation. To the extent that the first amendment stands for the proposition that governmental evaluation of citizens' beliefs is an evil in and of itself, patronage is constitutionally suspect. ${ }^{\mathbf{3 6 3}}$

By contrast, the Hatch Act entails neither a censorial evaluation of

ss8 Hatch Act, ch. 410, $\S 9($ a), 53 Stat. 1147, 1148 (codified as amended at 5 U.S.C. $§ 7324$ (1982)).

380 See Civil Serv. Comm'n v. National Ass'n of Letter Carriers, 413 U.S. 548 (1973); United Pub. Workers v. Mitchell, 330 U.S. 75 (1946).

${ }^{860}$ Elrod v. Burns, 427 U.S. 347 (1976).

${ }^{361}$ Id. at 380 (Powell, J., concurring).

sez See Blasi, The Checking Value in First Amendment Theory, 1977 AM. BAR Found. Research J. 521; see also Connick v. Myers, 103 S. Ct. 1684, 1690 (1983) (suggesting that an employee's political speech is more highly protected than her speech regarding "nonpublic" concerns).

s6s Similarly, the legality of the proposal to require pre-publication review by the government of publications by former officials who had access to classified documents, see Snepp v. United States, 444 U.S. 507 (1980) (awarding the government damages against a CIA agent for his breach of an agreement not to exercise his speech rights); National Security Directive-84 on Safeguarding National Security Information (Mar. 11, 1983), cited in H.R. REP. No. 578, 98th Cong., 1st Sess. 3 n.2 (1983) (directing all executive agencies to restrict the speech rights of employees who have had access to "sensitive compartmented information"), should turn not only on the characterization of the condition as a threat or an offer, but on the effect and nature of the decisions it places in the hands of government. An effective veto over criticism by former officials is a powerful tool for manipulating the availability of information to the electorate, even if the former officials have in some sense freely surrendered their rights. 
speech nor the establishment of a self-entrenching limitation on information flow. The silence of public employees in election campaigns is, in most cases, unlikely to perpetuate the power of those currently in control of the federal government. ${ }^{364}$

\section{G. The Problem of Remedy: The Right to Be a Policeman Revisited}

Whether rooted in a conclusion that the government has threatened to deny benefits or has offered to purchase inalienable rights, the decision that a given conditional allocation is unconstitutional faces a final hurdle. In the case of most constitutional rights, the courts have adopted the position that such rights may be infringed upon an appropriate showing of governmental justification. In this Article, I will proceed on the basis of this traditional understanding. ${ }^{305}$ Nonetheless, once it is clear that a constitutional liberty has been infringed or that a right should be treated as inalienable, there is no reason to apply a lower standard of justification to the prima facie unconstitutional governmental action than would be applied to a more traditional violation. Not every allocational threat to constitutional interests is unconstitutional, any more than is every criminal sanction. But, given the similarly grave potential impact of the allocational sanction on the victims,

sos Of course, the actual political situation may indicate that a political hysterectomy of public employees is also a substantial distortion of political discussion. If a large and distinctive voice is excluded from the political marketplace by means of employee waivers, a reevaluation may be called for. See Metromedia, Inc. v. City of San Diego, 453 U.S. 490, 518-19 (1981) (White, J., for plurality of four) (government restriction is impermissible if it eliminates certain topics from discussion); First Nat'l Bank v. Bellotti, 435 U.S. 765 (1978) (striking down a statute that criminalized corporate expenditures aimed at influencing votes in referendums).

ses I do so, however, without prejudice to the absolutist strand in constitutional analysis. See, e.g., the positions of Justice Black: Konigsberg v. State Bar, 366 U.S. 36 (1961) (Black, J., dissenting), Kalven, Upon Rereading Mr. Justice Black on the First Amendment, 14 UCLA L. REv. 428 (1967); Professor Baker: Baker, Realizing SelfRealization: Corporate Political Expenditures and Redish's Value of Free Speech, 130 U. PA. L. Rev. 646 (1982); Baker, The Process of Change and the Liberty Theory of the First Amendment, 55 S. CaL. L. REv. 293 (1981), Baker, Scope of the First Amendment Freedom of Speech, 25 UCLA L. REv. 964 (1978); and Professor Meiklejohn: A. Meiklejohn, Free SpeEch and Its Relation to Self-GovernMENT (1948); Meiklejohn, The First Amendment as an Absolute, 1961 SuP. Cr. REv. 245 (1961); Meiklejohn, What Does the First Amendment Mean, 20 U. CHI. L. REv. 461 (1953). I suspect, however, that while there is no necessary connection in logic between absolutism regarding justifications for impingement on protected speech and the sanctions against which speech is protected, many absolutists will feel uncomfortable with the scope of sanctions that raise prima facie constitutional violations under my analysis. Given an absolutist approach, the definition of a prima facie violation is the only way to protect against undesirable invalidations of acceptable government actions. See Schauer, Categories and the First Amendment: A Play in Three Acts, 34 Vand. L. REv. 265, 276 (1983) ("[A]bsolutism exerts an inward pull on the boundaries of coverage."). 
a similar requirement of justification seems appropriate. Even if the interest in close employer-employee relationships is compelling, Justice Rehnquist's "wide degree of deference to the employer's judgment" in evaluating the potential adverse impact of employee speech is unwarranted.

There may, however, be an institutional reason to be reluctant to find an allocational decision unconstitutional. Holmes's assertion that there is no right to be a policeman can also be seen as something more than a tautology. In addition to whatever import it carries for the limits of government power, the assertion that there is no right to be a policeman conceals remedial concerns. If Officer McAuliffe's contract violates the Constitution, the court must decide whether to void it entirely or to enforce it without the unconstitutional condition. If it adopts the former course, McAuliffe is not helped, he now has no job. If the latter path is taken, the court has judicially established a contract for services between the city and its police force, which it will enforce by injunctive decree or damages.

Whether because of a majoritarian disinclination to meddle in internal processes of elected government or because of a justifiable skepticism about the abilities of courts to allocate resources among competing claims, the judiciary has been reluctant to intervene in these sorts of decisions. ${ }^{367}$ If the plaintiff has a right to his job, that is one thing; there is no choice to be made. But if no absolute right can be pointed to, the court must make a comparative judgment, and the award of relief to the plaintiff will come at a definable cost to the rest of society. To pay McAuliffe damages will necessitate raising taxes or reducing services elsewhere. To reinstate him means that his replacement loses her. In contrast, simply enjoining prosecution saves resources.

Once again, this rationale is limited to its factual presuppositions. If granting the proposed benefit involves no incremental expenditure of funds-as in the case of access to an existing public facility-no reallocation is necessary. ${ }^{388}$ If the violation in question is a result of a reduction from a clearly defined baseline, then the baseline defines the appropriate remedy. Indeed, in the case of either a reduction in.historical benefits or a singling out of protected activities, there is reason to expect that funds are already there to pay for the proposed relief. And some

${ }^{368}$ Connick v. Myers, 103 S. Ct. 1684, 1692 (1983).

367 See Cumming v. Richmond County Bd. of Educ., 175 U.S. 528 (1899); O. Fiss, The Givil Rights Injunction 1, 38-45 (1978); Frug, The Judicial Power of the Purse, 126 U. PA. L. REv. 715, 732-57 (1978).

${ }_{363}$ Where the facility is privately owned, the problems multiply. See Karst, supra note 263 , at 51 . 
rights carry with them their own defined distributive choice. ${ }^{369}$

Similarly, the increasingly pervasive judicial vindication of institutional rights may undermine this argument against granting full protection from allocative sanctions. The first Justice Harlan, who elsewhere rejected the argument of the greater and the lesser in support of allocational sanctions ${ }^{370}$ adopted an uncharacteristically deferential posture in response to an equal protection challenge to an all-white high school in Georgia. ${ }^{371}$ In 1899, he reasoned, "It being in [the Board's discretion to establish high schools], they could, without a violation of the law or of any constitution, devote a portion of the taxes collected for school purposes to the support of this high school for white girls . . ."372 But this conclusion seems more rooted in his discussion of the remedial difficulties:

The substantial relief asked is an injunction that would either impair the efficiency of the high school provided for white children or compel the Board to close it. But if that were done, the result would only be to take from white children educational privileges enjoyed by them, without giving to colored children additional opportunities . . . . 373

For a court limited to use of a prohibitory injunction, the difficulties of righting an unconstitutional allocation might be sufficient to bar relief. But for a court operating after a generation of institutional relief, ${ }^{374}$ the problems seem smaller.

Nonetheless, depending on the depth of one's skepticism regarding the exercise of the judicial "power of the purse," 375 there may be reason to be reluctant to embroil the courts in allocative disputes. The cost of this reluctance, however, is a willingness to tolerate increasingly serious infringements of constitutional rights.

\section{ConCLUSION}

The dangers to liberties posed by a modern state reside as much in what it refrains from doing as in what it does. Once the government involves itself deeply in the economic and social life of its citizens-as

s69 See supra text accompanying notes $352-68$.
s70 See supra note 17 ; text accompanying note 165.
s71 See Cumming v. Richmond County Bd. of Educ., 175 U.S. 528 (1899).
s72 Id. at 542.
s73 Id. at 544 .
s74 See O. Fiss, supra note 367 , at 5; Chayes, The Role of the Judge in Public Law Litigation, 89 HARv. L. Rev. 1281 (1976); Fiss, The Supreme Court, 1978 Term-Foreword: Forms of Justice, 93 HARv. L. REv. 1 (1979).

s7s See Frug, supra note 367. 
decency, efficiency, and fairness dictate that it must, in order to meet the challenges of contemporary life - the state is in a position to manipulate its citizens as effectively by withholding largesse as by threatening prison. A constitutional jurisprudence that is to retain its vitality in the later twentieth century must deal with this reality. Courts should not insulate allocative sanctions from judicial review by accepting misleading a fortiori arguments, false analogies to private property holders, or gossamer distinctions between purportedly positive and negative rights. This essay will have succeeded in part of its purpose if it leaves the reader with the conviction that courts seeking to protect constitutional liberties run severe risks if they exempt allocational sanctions from constitutional scrutiny.

Yet, at the same time, past approaches to review of allocational sanctions are themselves flawed. A search for illicit governmental purposes leads into quandaries of definition and application, defines the constitutional right in terms of the government's intent rather than the citizen's liberties, and provides far too ample an opportunity for covert and unreviewable incorporation of value choices under the guise of factfinding. In counterpoint, an exclusive focus on the impact of the allocation at issue fails to account for the variety of impacts that allocational sanctions may, in fact, generate. Those who have urged a balancing approach to the problem have perhaps suggested answers that most frankly acknowledge the difficulties involved, but such suggestions have thus far been so loose as to be of little assistance in shaping arguments in the area.

The enterprise of this Article has been to develop a structure of inquiry that allows courts to incorporate the best of prior analyses. I have sought to disentangle two issues: first, the question of what conditional allocations may be said to be threats that reduce the autonomy guarded by constitutional liberties and, second, the question whether an allocation, be it threat or offer, should be viewed as an impermissible effort by government to induce sale of inalienable rights. It is my hope that this distinct will allow courts more easily to order intuitions and values and force them to discuss more explicitly the conflicts that arise. In distinguishing threats from offers, I have shown that the adoption of the appropriate baseline is crucial and problematic, but not so intractable as to leave the courts with no choice but resort to ad hoc categorization.

I do not pretend that analysis of history, equality, and prediction will compel outcomes in the most difficult cases. Nonetheless, the approach serves its purpose if it facilitates clearer dialogue, more pointed factual development, and more mature consideration of the moral and 
political choices involved than courts have been able to attain under the current regime. 
